SANDIA REPORT

SAND 2005-2628

Unlimited Release

Printed June 2005

\title{
Site Environmental Report for 2004 Sandia National Laboratories, California
}

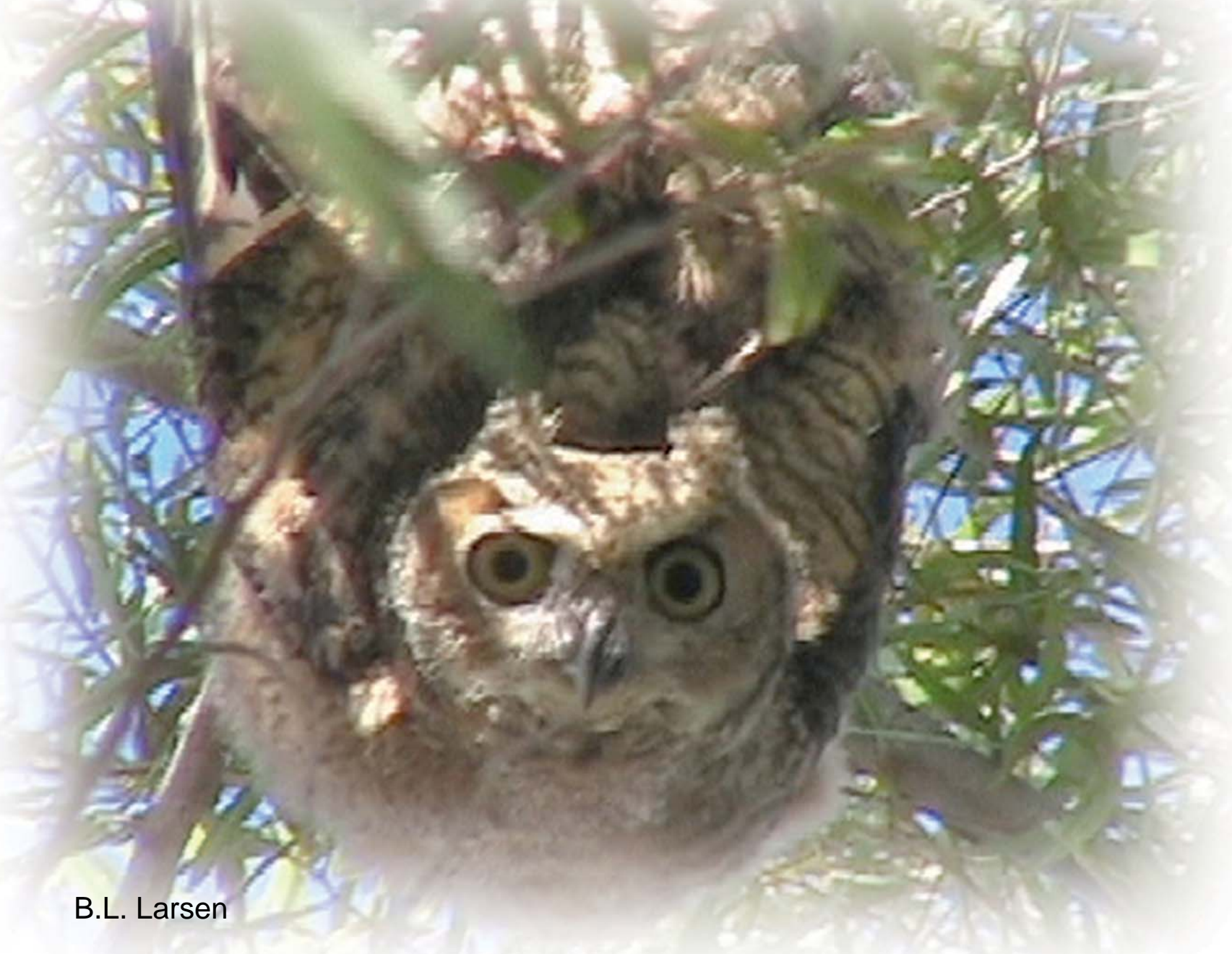

Prepared by

Sandia National Laboratories

Livermore, California 94550

Sandia is a multiprogram laboratory operated by Sandia Corporation, a Lockheed Martin Company, for the United States Department of Energy under Contract DE-AC04-94AL85000.

Approved for public release; further dissemination unlimited. 
Issued by Sandia National Laboratories, operated for the United States Department of Energy by Sandia Corporation.

NOTICE: This report was prepared as an account of work sponsored by an agency of the United States Government. Neither the United States Government, nor any agency thereof, nor any of their employees, nor any of their contractors, subcontractors, or their employees, make any warranty, express or implied, or assume any legal liability or responsibility for the accuracy, completeness, or usefulness of any information, apparatus, product, or process disclosed, or represent that its use would not infringe privately owned rights. Reference herein to any specific commercial product, process, or service by trade name, trademark, manufacturer, or otherwise, does not necessarily constitute or imply its endorsement, recommendation, or favoring by the United States Government, any agency thereof, or any of their contractors or subcontractors. The views and opinions expressed herein do not necessarily state or reflect those of the United States Government, any agency thereof, or any of their contractors.

Printed in the United States of America. This report has been reproduced directly from the best available copy.

Available to DOE and DOE contractors from

U.S. Department of Energy

Office of Scientific and Technical Information

P.O. Box 62

Oak Ridge, TN 37831

Telephone: $\quad$ (865) 576-8401

Facsimile: (865) 576-5728

E-Mail:_reports@adonis.osti.gov

Online ordering: http://www.doe.gov/bridge

Available to the public from

U.S. Department of Commerce

National Technical Information Service

5285 Port Royal Road

Springfield, VA 22161

Telephone: (800) 553-6847

Facsimile: (703) 605-6900

E-Mail:_orders@ntis.fedworld.gov

Online order: http://www.ntis.gov/ordering.htm

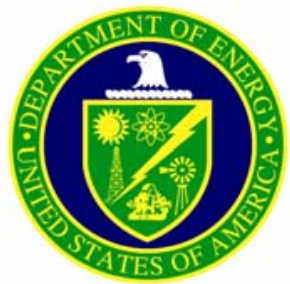


SAND 2005-2628

Unlimited Release

Printed June 2005

\title{
Site Environmental Report for 2004 Sandia National Laboratories, California
}

\author{
Barbara L. Larsen \\ Environmental Operations Department \\ Sandia National Laboratories, California
}

\begin{abstract}
Sandia National Laboratories, California (SNL/CA) is a government-owned/contractoroperated laboratory. Sandia Corporation, a Lockheed Martin Company, operates the laboratory for the Department of Energy's (DOE) National Nuclear Security Administration. The DOE Sandia Site Office oversees operations at the site, using Sandia Corporation as a management and operating contractor. This Site Environmental Report for 2004 was prepared in accordance with DOE Order 231.1A. The report provides a summary of environmental monitoring information and compliance activities that occurred at SNL/CA during calendar year 2004. General site and environmental program information is also included.
\end{abstract}




\title{
Preface
}

Each year, Sandia National Laboratories, California (SNL/CA) prepares a summary report to provide environmental information to the local community, pursuant to the requirements of Department of Energy Order 231.1A. The Site Environmental Report for 2004 summarizes SNL/CA's compliance with environmental requirements, presents the results of monitoring and surveillance activities, and provides an update of site environmental programs.

The Site Environmental Report for 2004 was prepared for ease in readability. Each chapter focuses on a specific topic or area. Reference to other sections and chapters is made throughout the report to avoid redundancy. Detailed data is provided only when necessary to improve the presentation of information and the quality of the document. Acronyms are defined within each chapter as well as listed at the beginning of the report. References are compiled into one list and presented at the end of the document.

This report was prepared by the SNL/CA Environmental Operations Department under the direction of Gary Shamber, and reviewed and approved by the Department of Energy, Sandia Site Office. The primary author is Barbara Larsen. Key contributors of information for the document are Mark Brynildson, Deanna Dicker, Laurie Farren, Leighton Ford, Leslee Gardizi, Janet Harris, Robert Holland, Rick Shih, and Warren TenBrook. Sandy Leo provided technical editing for the document, assisted with verifying text accuracy, and provided support with technical writing. The cover photograph was provided by Joanne Sartor.

Additional information about this report can be obtained from:

\author{
Sandia National Laboratories, California \\ Public and Media Relations Office \\ P.O. Box 969 \\ Livermore, CA 94551-0969 \\ Attention: Mike Janes \\ Phone: (925) 294-2447 \\ e-mail: mejanes@sandia.gov \\ or \\ U.S. Department of Energy \\ National Nuclear Security Administration \\ Sandia Site Office \\ P.O. Box 5400 \\ Albuquerque, NM 87185-5400 \\ Attention: Karen Agogino \\ Phone: (505) 845-6100 \\ e-mail: kagogino@doeal.gov
}




\section{Contents}

1 Executive Summary ...............................................................................................1-1

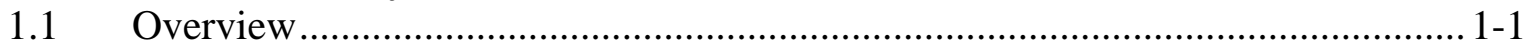

1.2 Performance Measures........................................................................... 1-1

$1.3 \quad$ Environmental Management ....................................................................... 1-1

$1.4 \quad$ Environmental Monitoring............................................................................ 1-2

2 Introduction............................................................................................................... 2-1

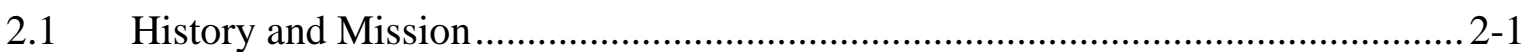

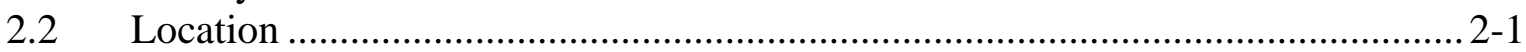

2.3 Site Population ............................................................................................. 2-3

$2.4 \quad$ Environmental Setting ............................................................................ 2-3

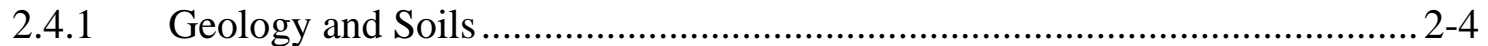

2.4.2 Hydrology and Water Resources ...................................................................2-5

2.4.3 Climate and Meteorology ………………............................................. 2-6

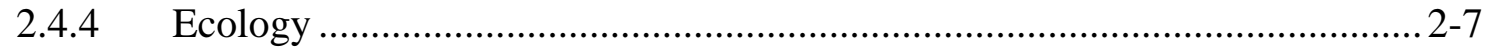

3 Compliance Summary ….................................................................................................. 3-1

3.1 DOE Order 450.1 ..............................................................................

3.2 National Environmental Policy Act..................................................................... 3-1

3.3 Air Quality …………………………………......................................... 3-2

3.3.1 Clean Air Act ................................................................................... 3-2

3.3.2 Radionuclide Emissions............................................................................. 3-2

3.4 Natural and Cultural Resources .................................................................... 3-3

3.4.1 Endangered Species Act ...................................................................

3.4.2 Migratory Bird Treaty Act ........................................................................ 3-3

3.4.3 Floodplain Management ...................................................................... 3-4

3.4.4 Protection of Wetlands........................................................................... 3-4

3.4.5 National Historic Preservation Act .................................................................. 3-4

3.5 Environmental Restoration ........................................................................ $3-5$

3.5.1 Comprehensive Environmental Response, Compensation, and

Liability Act...................................................................................

3.5.2 Site Clean-up Orders.......................................................................... 3-5

3.6 Hazardous Materials ............................................................................................. 3-6

3.6.1 Emergency Planning and Community Right-to-Know Act ................................3-6

3.6.2 California Hazardous Materials Release Response Plans and

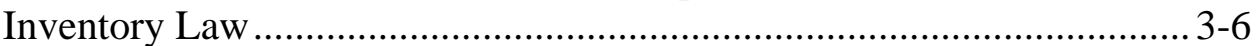

3.6.3 Underground Storage Tanks .................................................................

3.6.4 Toxic Substances Control Act ………………........................................... 3-7

3.6.5 Federal Insecticide, Fungicide, and Rodenticide Act ..................................... 3-7

3.7 Pollution Prevention and Waste Minimization ....................................................... 3-7

3.7.1 Executive Order 13101 ...................................................................... 3-7

3.7.2 Hazardous Waste Source Reduction and Management Review Act ..............3-8

3.7.3 Pollution Prevention Act......................................................................

3.8 Hazardous Waste ............................................................................................ 3-8

3.8.1 Federal Facility Compliance Act ………….................................................... 3-8 
3.8.2 Resource Conservation and Recovery Act ............................................. 3-9

3.8.3 California Hazardous Waste Control Law ......................................................... 3-9

3.8.4 Medical Waste Management Act.................................................................. 3-10

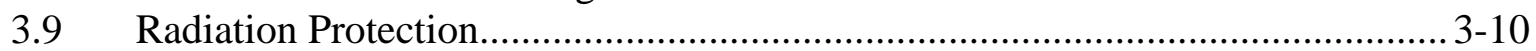

3.9.1 Atomic Energy Act ........................................................................ 3-10

3.9.2 DOE Order 435.1, Radioactive Waste Management .................................. 3-10

3.9.3 DOE Order 5400.5, Radiation Protection of the Public and the

Environment....................................................................................... 3-10

3.10 Water Quality and Protection.................................................................... 3-11

3.10.1 Clean Water Act............................................................................. 3-12

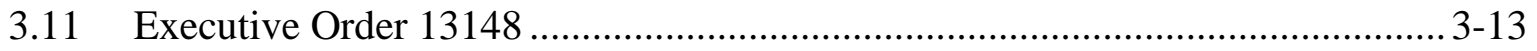

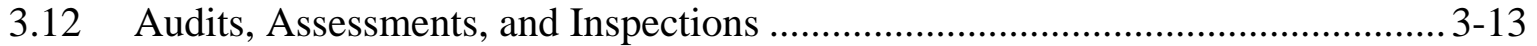

3.13 Environmental Occurrences .......................................................................... 3-14

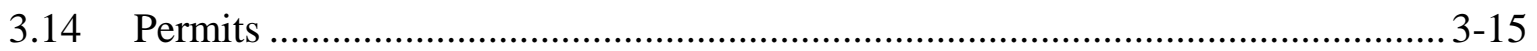

4 Environmental Program Information................................................................ 4-1

4.1 Environmental Management ................................................................... 4-1

4.2 Environmental Performance .................................................................. 4-2

Environmental Programs .......................................................................... 4-2

4.3.1 Environmental Program Highlights ........................................................ 4-3

5 Environmental Monitoring ......................................................................................... 5-1

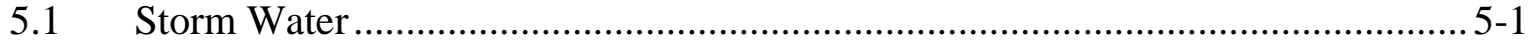

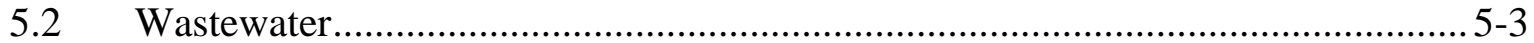

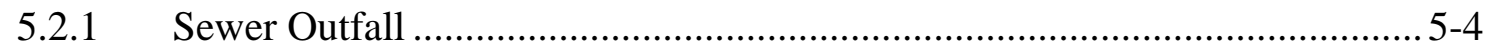

5.2.2 Liquid Effluent Control System.......................................................... 5-8

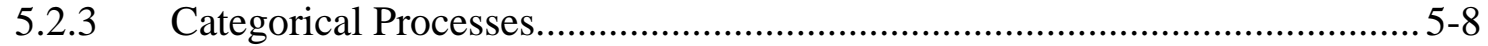

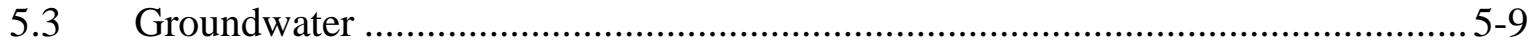

5.4 Biological Dose Assessment........................................................................ 5-13

5.5 Radiation Monitoring ......................................................................... 5-14

6 Quality Assurance................................................................................................................. 6-1

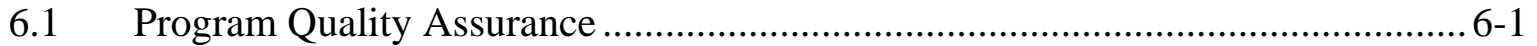

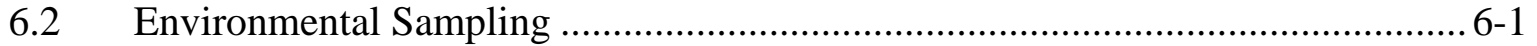

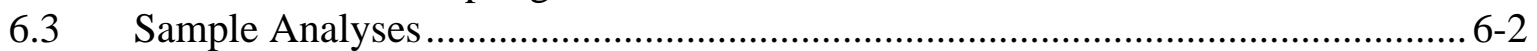

6.3.1 Accredited Laboratory ......................................................................... 6-2

6.3.2 SNL/CA Health Physics Laboratory ...................................................... 6-2

6.3.3 SNL/NM Health Instrumentation Laboratory ........................................... 6-2

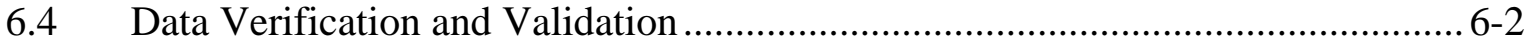

6.4.1 Quality Control Samples....................................................................... 6-2

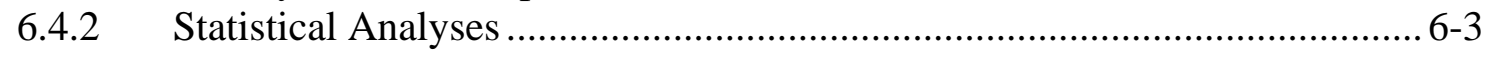

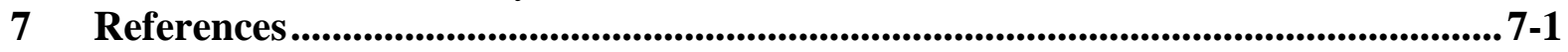

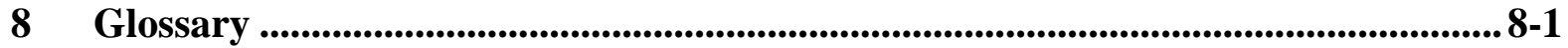

9 Groundwater Analytical Results ...................................................................9 9-1

10 Distribution List .................................................................................................1 10-1 


\section{Tables}

Table 3-1 Status of EPCRA Reporting at SNL/CA, 2004 .........................................................6

Table 3-2 Order 5400.5 Compliance Summary, 2004 .........................................................3-11

Table 3-3 Wastewater Discharge Permit Exceedances at Sanitary Sewer Outfall, 2004......3-12

Table 3-4 SNL/CA Activities in Support of Executive Order 13148 ......................................3-14

Table 3-5 SNL/CA Audits, Assessments, and Inspections, 2004 ............................................15

Table 3-6 SNL/CA Environmental Permits and Orders, 2004 …..............................................3-16

Table 4-1 Criteria Pollutant Emission Rates at SNL/CA and for the

San Francisco Bay Area Basin............................................................................4-3

Table 4-2 Toxic Emission Rates at SNL/CA and for the San Francisco Bay Area Basin......4-4

Table 4-3 Comparison of 2004 Operations with SWEA Envelope ...........................................4-6

Table 4-4 SNL/CA Recycling Data, 2004 ...............................................................................

Table 4-5 Waste Generated at SNL/CA, 2003 and 2004 .........................................................4-8

Table 5-1 Summary of Analytical Results for Storm Water, 2003/2004 Wet Season ............5-3

Table 5-2 Sewer Outfall Sampling Schedule, 2004 …..............................................................5-4

Table 5-3 Weekly Composite Sewer Outfall Monitoring Results -

Physical Parameters and Metals, 2004................................................................5-5

Table 5-4 Batch Discharges and Monitoring for Metal Finishing Categorical

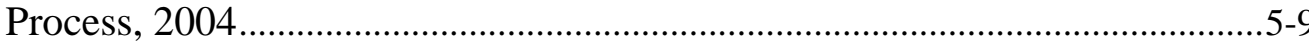

Table 5-5 Monitoring for Semiconductor Manufacturing Categorical Process, 2004 ............5-9

Table 5-6 Groundwater Sampling Schedule, 2004 .........................................................5-10

Table 5-7 Summary of Groundwater Analyses at Navy Landfill and Trudell Wells, 2004 .5-11

Table 5-8 Summary of Groundwater Analyses at Arroyo Seco Wells, 2004.........................5-12

Table 5-9 Summary of Groundwater Analyses for Emergent Chemical Sampling, 2004....5-13

Table 6-1 Summary of Statistical Analyses, 2004 ............................................................6-4

Table 9-1 Results of Quarterly Groundwater Analyses at SNL/CA, 2004 .............................9-2 


\section{Figures}

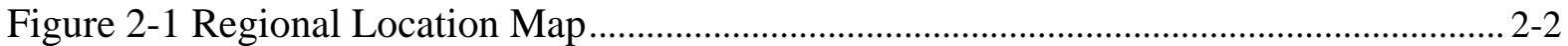

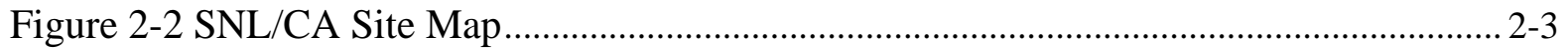

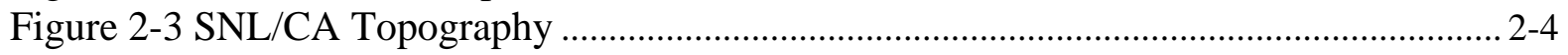

Figure 2-4 Regional Earthquake Faults................................................................................ 2-5

Figure 2-5 Wildlife and Habitat at SNL/CA, 2004............................................................... 2-8

Figure 4-1 Total Recycled Materials at SNL/CA, 1999 to 2004 ........................................... 4-8

Figure 5-1 Storm Water Sampling Locations.................................................................. 5-2

Figure 5-2 Weekly Composite Copper Concentrations in Wastewater, 1992 - 2004 ............ 5-6

Figure 5-3 Weekly Composite Zinc Concentrations in Wastewater, 1992 - 2004 ................. 5-6

Figure 5-4 Weekly Composite Copper Concentrations in Wastewater, 2000 - 2004 ............ 5-7

Figure 5-5 Weekly Composite Zinc Concentrations in Wastewater, 2000 - 2004 ................ 5-7

Figure 5-6 Groundwater Monitoring Well Locations ............................................................ 5-11

Figure 5-7 Dosimeter Locations at SNL/CA and Around Site Perimeter ............................ 5-15

Figure 5-8 Dosimeter Locations in Livermore Valley …....................................................... 5-16 


\section{Acronyms and Abbreviations}

\begin{tabular}{|c|c|}
\hline ALARA & as low as reasonably achievable \\
\hline BAAQMD & Bay Area Air Quality Management District \\
\hline BTEX & benzene, toluene, ethylbenzene, and xylene \\
\hline CCR & California Code of Regulations \\
\hline CARB & California Air Resources Board \\
\hline CEARP & Comprehensive Environmental Assessment and Response Program \\
\hline CERCLA & Comprehensive Environmental Response, Compensation, and Liability Act \\
\hline CFR & Code of Federal Regulations \\
\hline CRMP & Cultural Resource Management Plan \\
\hline DOE & Department of Energy \\
\hline DOE/SSO & Department of Energy, Sandia Site Office \\
\hline DTSC & Department of Toxic Substances Control (California) \\
\hline EMS & environmental management system \\
\hline $\mathrm{EO}$ & executive order \\
\hline EPA & Environmental Protection Agency \\
\hline EPCRA & Emergency Planning and Community Right-to-Know Act \\
\hline ES\&H & environment, safety, and health \\
\hline FIFRA & Federal Insecticide, Fungicide, and Rodenticide Act \\
\hline FONSI & Finding of No Significant Impact \\
\hline $\begin{array}{l}\text { General } \\
\text { Construction } \\
\text { Permit }\end{array}$ & $\begin{array}{l}\text { State of California, NPDES General Permit to Discharge Storm Water } \\
\text { Associated with Construction Activity }\end{array}$ \\
\hline $\begin{array}{l}\text { General } \\
\text { Permit }\end{array}$ & $\begin{array}{l}\text { State of California, NPDES General Permit for Storm Water Discharge } \\
\text { Associated with Industrial Activities }\end{array}$ \\
\hline ISMS & integrated safety management system \\
\hline $\mathrm{kg}$ & kilogram \\
\hline $\mathrm{kg} / \mathrm{yr}$ & kilogram per year \\
\hline LECS & liquid effluent control system \\
\hline LLNL & Lawrence Livermore National Laboratory \\
\hline MCLs & maximum contaminant levels \\
\hline $\mathrm{mg} / \mathrm{L}$ & milligrams per liter \\
\hline mrem & millirem \\
\hline $\mathrm{mSv}$ & milliSeivert \\
\hline ND & non-detectable \\
\hline
\end{tabular}




$\begin{array}{ll}\text { NEPA } & \text { National Environmental Policy Act } \\ \text { ng/L } & \text { nanogram per liter } \\ \text { NNSA } & \text { National Nuclear Security Administration } \\ \text { NPDES } & \text { national pollutant discharge elimination system } \\ \text { ODS } & \text { ozone depleting substances } \\ \text { PCB } & \text { polychlorinated biphenyl } \\ \text { pCi/L } & \text { picocuries per liter } \\ \text { POTW } & \text { publicly owned treatment works } \\ \text { PP/WM } & \text { Pollution Prevention and Waste Minimization } \\ \text { QAP } & \text { quality assurance program } \\ \text { QAPP } & \text { quality assurance program plan } \\ \text { RCRA } & \text { Resource Conservation and Recovery Act } \\ \text { RWQCB } & \text { Regional Water Quality Control Board (California) } \\ \text { SARA } & \text { Superfund Amendments and Reauthorization Act of 1986, Title III } \\ \text { Title III } & \\ \text { SNL } & \text { Sandia National Laboratories } \\ \text { SNL/CA } & \text { Sandia National Laboratories, California } \\ \text { SNL/NM } & \text { Sandia National Laboratories, New Mexico } \\ \text { SWEA } & \text { Site-wide Environmental Assessment } \\ \text { TPHD } & \text { total petroleum hydrocarbons diesel } \\ \text { TRI } & \text { toxic release inventory } \\ \text { TSCA } & \text { Toxic Substances Control Act } \\ \mu \text { g/L } & \text { micrograms per liter } \\ \text { U.S. } & \text { United States } \\ \text { USC } & \text { United States Code } \\ \text { USFWS } & \text { United States Fish and Wildlife Service } \\ \text { UST } & \text { underground storage tank } \\ & \end{array}$




\section{Executive Summary}

\subsection{Overview}

Sandia National Laboratories is one of three national laboratories supporting the U.S. Department of Energy (DOE) statutory responsibilities for nuclear weapon research and design, development of energy technologies, and basic scientific research. Sandia has facilities in New Mexico, California, Nevada, and Hawaii. Sandia National Laboratories, California (SNL/CA) is a multi-program engineering and science laboratory supporting the nuclear weapons stockpile program, energy and environment research, homeland security, micro- and nano-technologies, and basic science and engineering research.

The Site Environmental Report provides a summary of environmental management performance and compliance efforts at SNL/CA for calendar year 2004. The document also satisfies the DOE requirement for preparation of an annual environmental report as listed in DOE Order 231.1A, Environment, Safety, and Health Reporting (DOE 2003d). The objective of DOE Order 231.1A is to ensure timely collection, reporting, analysis, and dissemination of information on environment, safety, and health (ES\&H) issues at DOE facilities.

The Site Environmental Report is divided into ten chapters. Chapter 1, the Executive Summary, highlights compliance and monitoring results obtained in 2004. Chapter 2 provides a brief introduction to SNL/CA and the existing environment found onsite. Chapter 3 summarizes SNL/CA's compliance activities with the major environmental requirements applicable to site operations. Chapter 4 presents information on environmental management, performance measures, and environmental programs. Chapter 5 presents the results of monitoring and surveillance activities in 2004. Chapter 6 discusses quality assurance. Chapters 7 through 9 provide supporting information for the report and Chapter 10 is the report distribution list.

\subsection{Performance Measures}

SNL/CA's environmental performance is evaluated against corporate-wide performance measures established jointly by the DOE/Sandia Site Office (DOE/SSO) and Sandia Corporation. For fiscal year 2004 (October 1, 2003 through September 30, 2004), environmental performance is included as part of the operations performance group. The overall rating for this performance group for fiscal year 2004 is "good.” Additional information about performance measures is provided in Chapter 4.

\subsection{Environmental Management}

Environmental management at Sandia facilities, including SNL/CA, reflects a comprehensive program, or environmental management system (EMS) that combines compliance-related activities with stewardship. EMS is aligned with the Sandia Integrated Safety Management System (ISMS). EMS/ISMS is further enhanced with corporate policies, an ES\&H 
compliance manual, environmental programs, and ES\&H councils, committees, and teams. During 2004, SNL/CA continued to define and implement a site-specific EMS that is tailored to the environmental risks applicable to California operations. Additional information on environmental management is presented in Section 4.1.

\subsection{Environmental Monitoring}

SNL/CA monitors storm water, wastewater, groundwater, and direct (ambient) radiation. The results of monitoring show that no pollutants were detected in storm water runoff at levels that are a cause for concern, and that all wastewater generated by site operations complied with the site outfall discharge limits for regulated physical parameters and most metals. The site exceeded the discharge limit for copper at the sewer outfall on one occasion in 2004. SNL/CA continued to see carbon tetrachloride in groundwater at the Navy Landfill in 2004 with a concentration similar to that detected in past years. Wells at the Fuel Oil Spill site and well AS-3A were dry during 2004; consequently, no samples were collected. Monitoring data indicate that SNL/CA is not contributing significantly to the external radiation dose in the area. The average annual external radiation dose at the site perimeter was 60 mrem $(0.60$ $\mathrm{mSv}$ ), which is within the dose range measured over the last ten years. Additional information about environmental monitoring at SNL/CA is provided in Chapter 5. 


\section{Introduction}

\subsection{History and Mission}

Sandia National Laboratories, California (SNL/CA) was established in 1956 by Sandia Corporation to provide a closer relationship with Lawrence Livermore National Laboratory (LLNL) and their nuclear weapons design work. The SNL/CA facility evolved into an engineering research and development laboratory by the early 1960s, and into a multiprogram engineering and science laboratory during the 1970s. As international arms control efforts increased in the late 1970s and throughout the 1980s, the United States emphasized treaty monitoring, safety, security, and control of the national nuclear weapons stockpile. With the end of the Cold War in the late 1980s, the role of SNL/CA to support stockpile stewardship ensuring nonproliferation and continued safety, security, and reliability, took on greater importance.

\section{Research Activities at SNL/CA}

$>$ Science-based performance and reliability testing and computer-based modeling of nuclear weapon components

$>$ Development, design, and testing of nonnuclear components for nuclear weapon systems

$>$ Development and testing of materials and diagnostic equipment in support of defense programs, homeland security, and basic science and engineering

$>$ Energy and environmental research

$>$ Research and development of microelectronics, microsystems, and nanotechonolgies
SNL/CA is a national laboratory dedicated to enabling global peace through unmatched contributions to our nation's security. Our core mission is exceptional stewardship of the nation's nuclear deterrent through valued solutions offered by our science based engineering approach. The mission and approach are expanded by broader roles in national security emphasizing defense and nonproliferation of weapons of mass destruction, energy and information surety, and unique contributions to our nation's conventional military capabilities.

SNL/CA is a government owned/contractor operated laboratory. The site, the buildings, and

the equipment are owned by the government; while Sandia Corporation, a Lockheed Martin Company, operates the laboratory for the Department of Energy's (DOE) National Nuclear Security Administration. The DOE/Sandia Site Office (DOE/SSO) oversees the operations at the site, using Sandia Corporation as a management and operating contractor.

\subsection{Location}

SNL/CA is located approximately 40 miles east of San Francisco, near the City of Livermore in eastern Alameda County. The site lies at the western base of the Altamont Hills on relatively flat terrain with low relief sloping gently northwest and north. Figure 2-1 shows the regional location of the site. 
SNL/CA occupies 410 acres. The main campus (134 acres) is surrounded on the east, south and west by undeveloped land (Figure 2-2, Site Map). To the north of SNL/CA are East Avenue and LLNL. Land use to the east and south of the site is agricultural and low-density residential. To the west of SNL/CA, construction continues on a residential development that began in 2003.

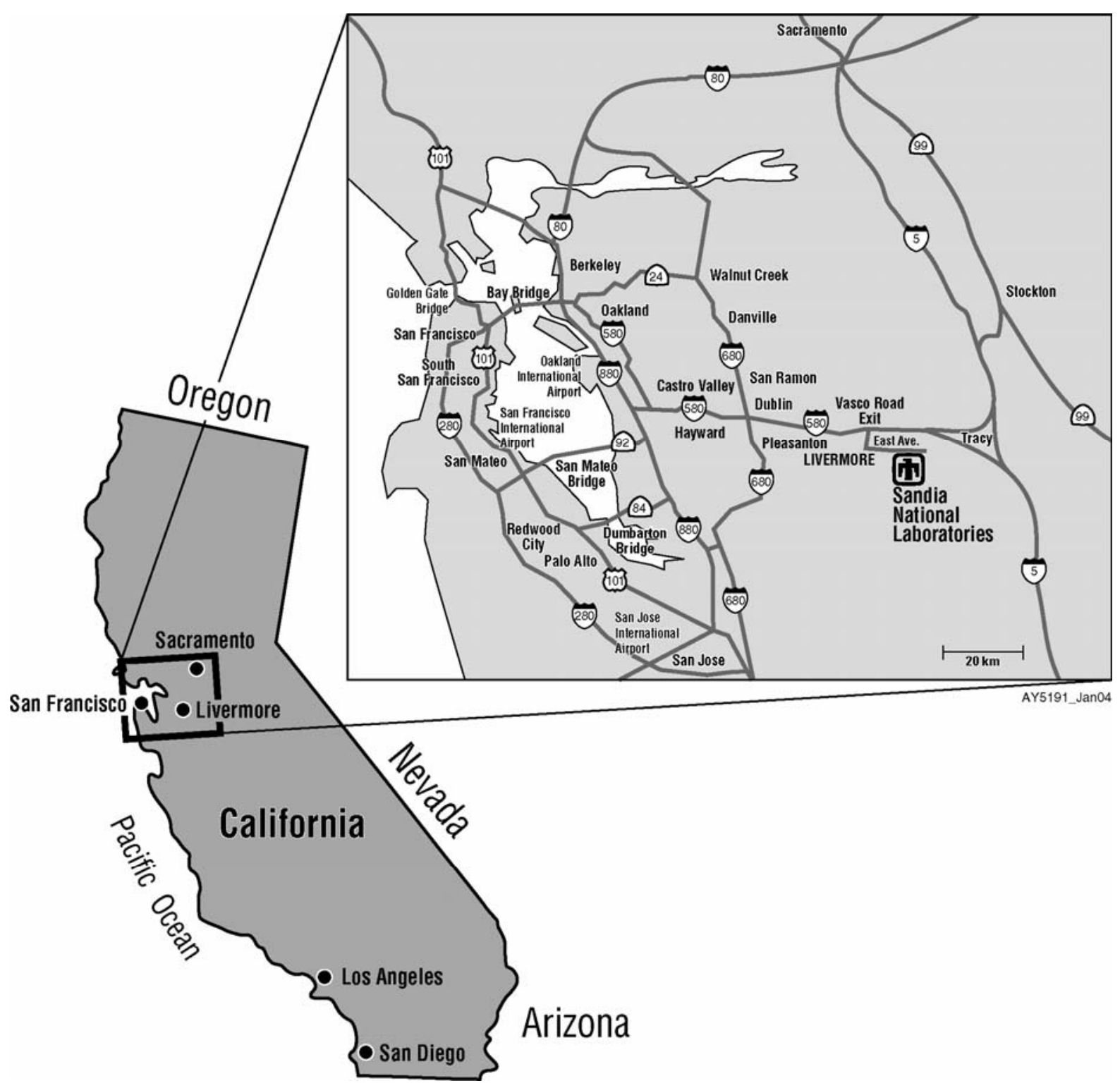

Figure 2-1 Regional Location Map 


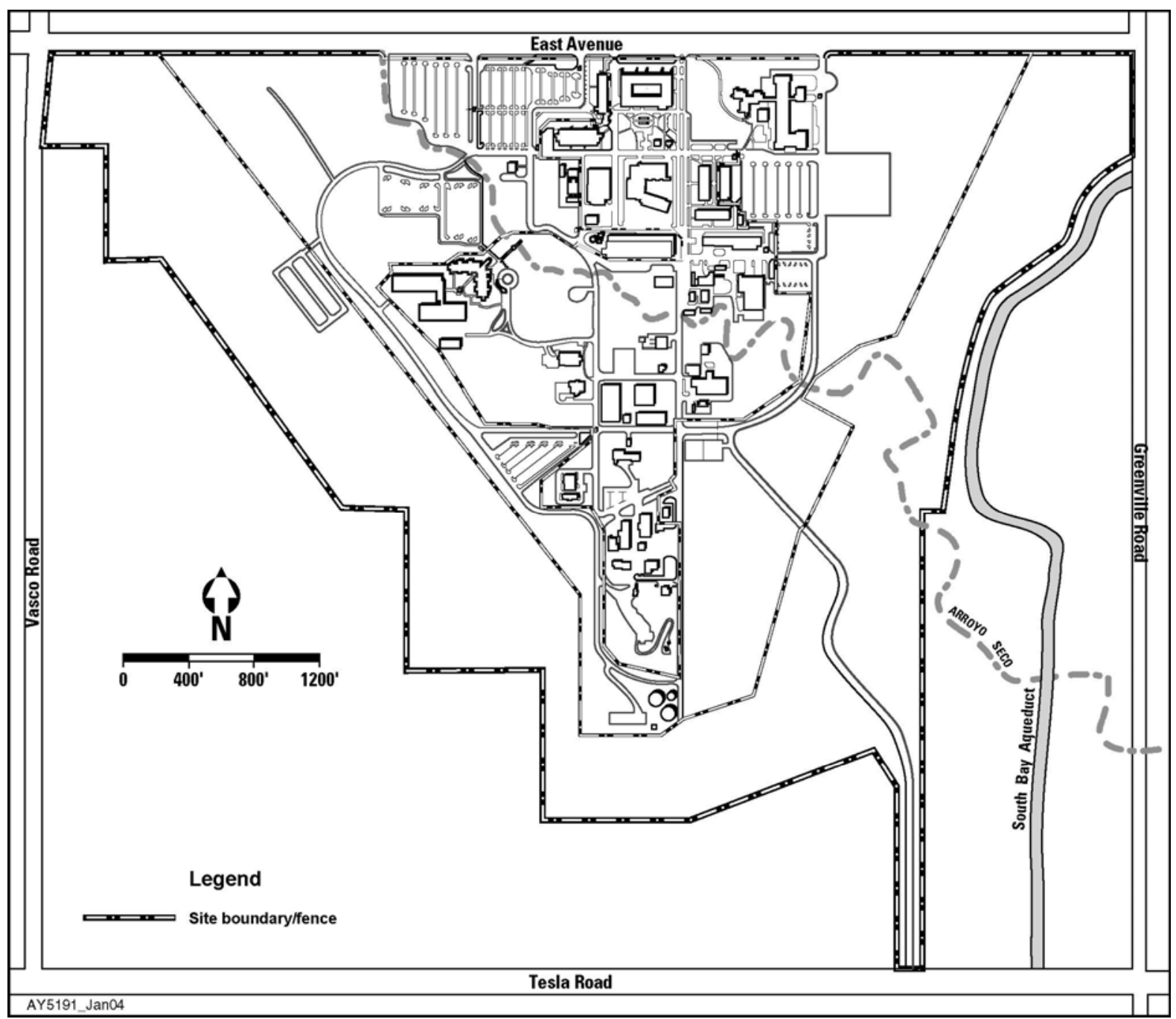

Figure 2-2 SNL/CA Site Map

\subsection{Site Population}

The SNL/CA workforce is comprised of Sandia employees (full and part-time staff, student interns, and post-doctoral appointees) and contractor staff. In September 2004, there were 1094 Sandia employees working at SNL/CA, an increase of 27 from 2003. Eighty-five percent of Sandia employees live in Alameda, Contra Costa, and San Joaquin counties. Thirty-six percent live in Livermore. The contractor workforce fluctuates throughout the year depending on program staffing needs. An estimate of contractor staff is not available.

\subsection{Environmental Setting}

The following summarizes the environmental setting at SNL/CA. Additional information can be found in the Final Site-wide Environmental Assessment of the Sandia National Laboratories/California (DOE 2003a). 


\subsubsection{Geology and Soils}

SNL/CA is located in the California Coast Ranges geologic province in the southeastern portion of the Livermore Valley. The valley forms an irregularly shaped lowland area about 16 miles long, east to west, and 7 to 10 miles wide, north to south. The land at SNL/CA slopes gently to the northwest and north, with steep terrain in the southern portion of the site and along the banks of Arroyo Seco. The site ranges in elevation from 615 feet above mean sea level at the northwest corner of the property to 849 feet at the southern end. Site topography is depicted on Figure 2-3.

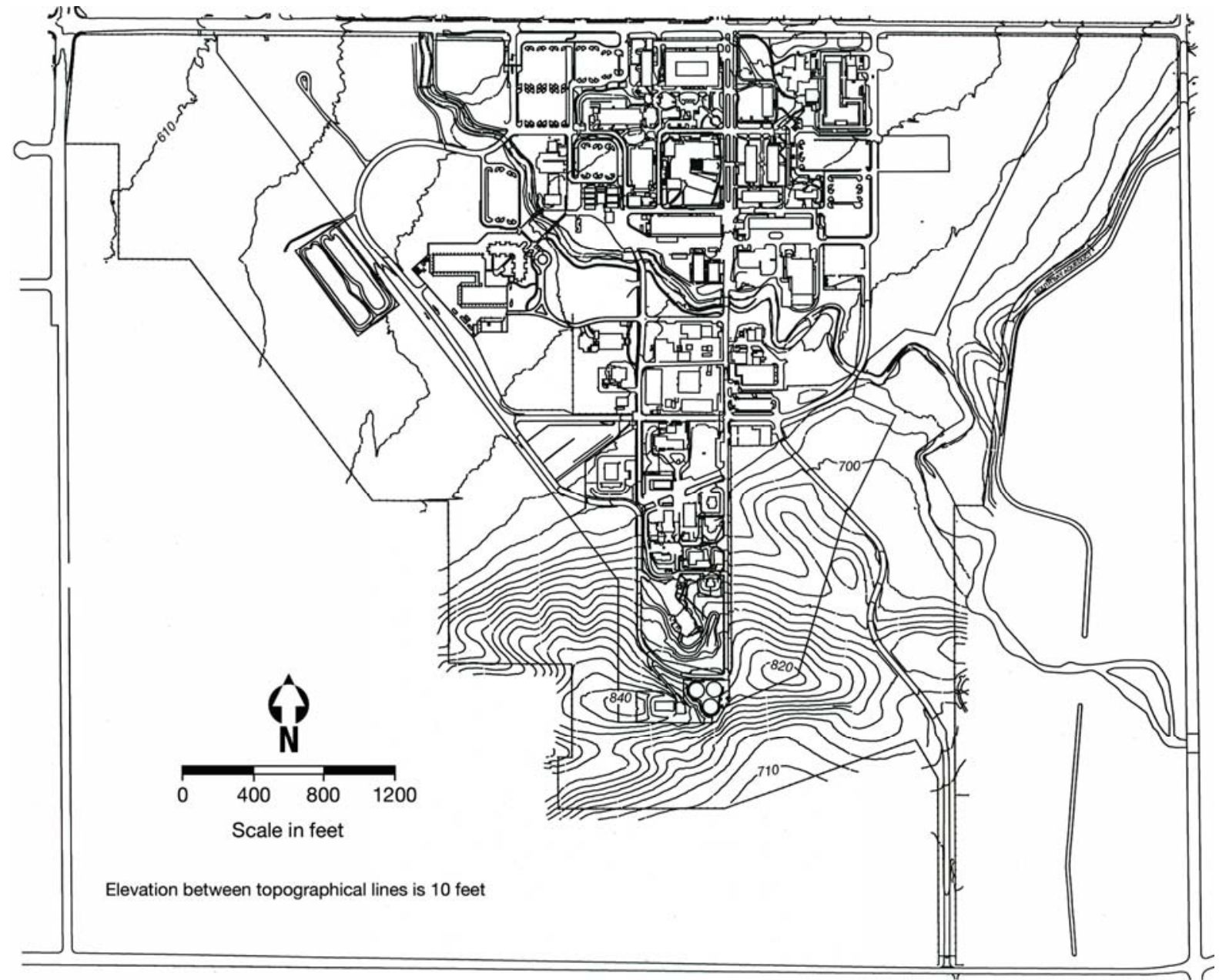

Figure 2-3 SNL/CA Topography

SNL/CA is located in a seismically active region. The major fault systems in the area are the San Andreas Fault system and the much older Coast Range thrust fault system. The upper plate of the Coast Range thrust formed the northwest trending Coast Range, including the Altamont Hills. Any seismic activity in the Livermore Valley would probably result from movement on the San Andreas Fault, a right-lateral strike-slip fault system trending northwest-southeast, extending from Point Arena to the Gulf of California. The regional faults closest to SNL/CA, the Hayward, Calaveras, Greenville, and Tesla faults follow this trend, and have been seismically active in the historic past. A magnitude 5.8 earthquake on 
the Greenville fault in 1980 caused minor damage at SNL/CA and in the Livermore Valley. The Las Positas fault crossing SNL/CA is a transverse fault, at right angles to the Greenville fault, and was active during this earthquake. The Verona fault is a low angle thrust fault, dissimilar to the regional faulting, and probably not connecting with either the Calaveras or Las Positas faults. Only microseismicity was recorded on the Verona fault in 1980. These faults are shown on Figure 2-4.

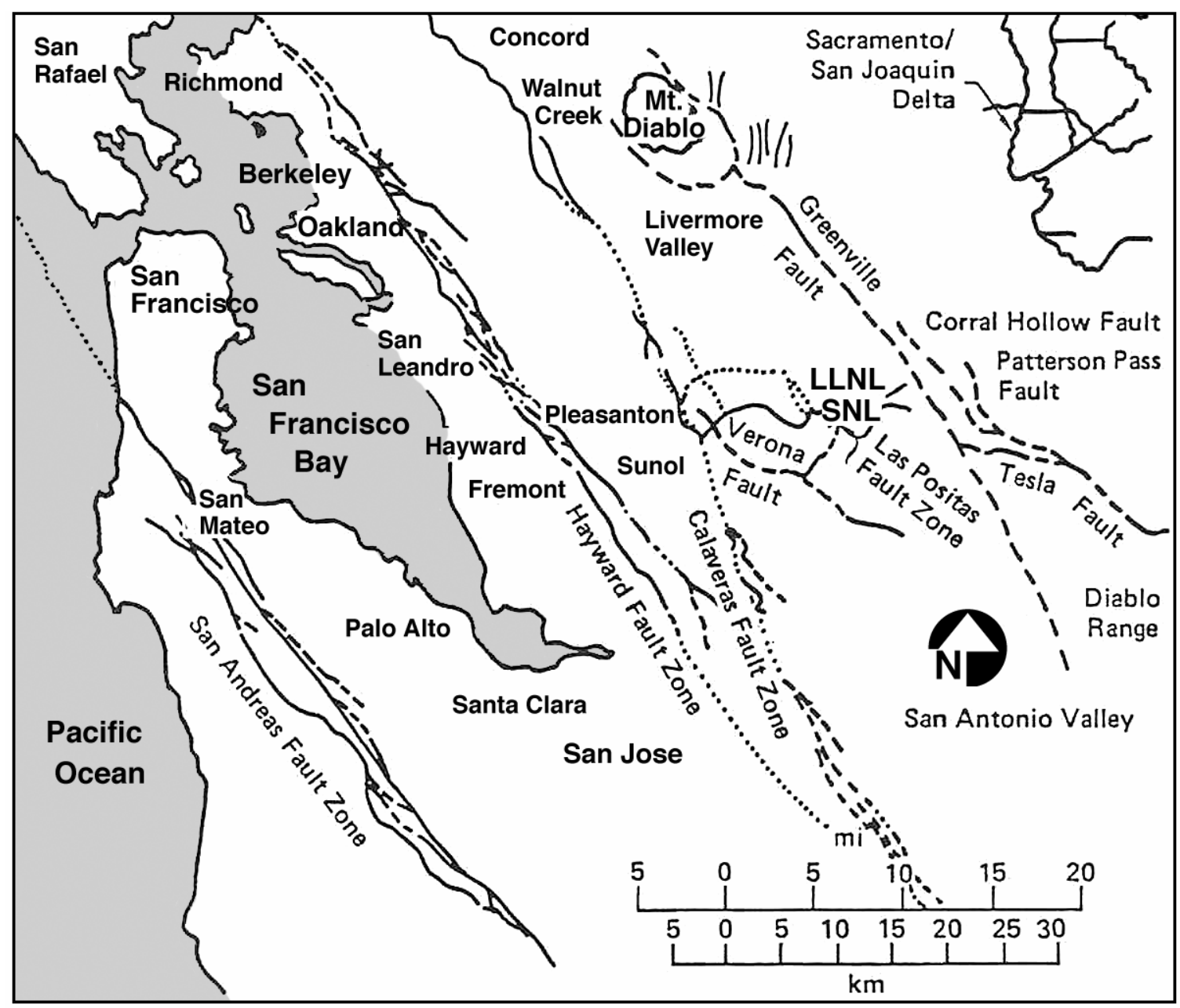

Figure 2-4 Regional Earthquake Faults

Surface soils and arroyo sediments cover the SNL/CA site. Underlying soils at the site are formed primarily upon sediments deposited by local streams. Three soils cover most of SNL/CA: Rincon clay loam, Positas gravelly loam, and Livermore gravelly loam. There are no known mineral resources or fossil occurrences at the site.

\subsubsection{Hydrology and Water Resources}

Groundwater in the SNL/CA area occurs within saturated unconsolidated geologic material. Depth to groundwater varies from less than 20 feet on the eastern portion of the site to 126 feet on the west side of the site. Water bearing-units beneath the site are composed of shallow heterogeneous, unconsolidated alluvium and deep fluvial and lacustrine sediments. 
Groundwater near SNL/CA is generally suitable for use as domestic, municipal, agricultural, and industrial supply. However, some shallower groundwater may be of marginal quality and not suitable for industrial or agricultural purposes. Groundwater less than 300 feet deep is usually unsuitable for domestic use without treatment.

SNL/CA purchases potable water from LLNL, who is supplied by the San Francisco Water District through the Hetch Hetchy Aqueduct. Additionally, the Alameda County Flood Control and Water Conservation District, Zone 7, supplements this primary water source as needed. SNL/CA's water use is not separately metered but is estimated to be 20 percent of LLNL's water use. In 2004, SNL/CA used an estimated 95.8 million gallons of water, an increase of 43.2 million gallons over 2003. This increase is the result of periodic shifts to Zone 7 water during 2004 while the Hetch Hetchy system underwent earthquake retrofit. Because Zone 7 water has a higher mineral content, more frequent cooling tower blow-down is required. The site discharged approximately 12.1 million gallons of wastewater during the year. Water loss, or the difference between water use and wastewater discharge, is attributed to irrigation, cooling towers, water tank releases, evaporative losses, eyewash and safety shower testing, fire system testing, and wash water from liquid effluent control system tanks that is trucked offsite for disposal.

There are no perennial streams or natural surface water bodies at SNL/CA. The Arroyo Seco, an ephemeral and intermittent stream, diagonally traverses the site from southeast to northwest. The arroyo typically flows only in very wet years, and for short periods of time during heavy storms. A seasonal wetland that is wet well into June, and sometimes July, is located in the stream bed along the eastern part of the arroyo. Storm water runoff at SNL/CA is conveyed to Arroyo Seco through a system of storm drains and channels. The Arroyo Seco and seasonal wetland are shown on Figure 2-5.

Two manmade ponds, encompassing approximately 2.7 acres, are located in the west outer perimeter area at SNL/CA. These ponds were constructed by LLNL in 1989 and served as a recharge basin for their groundwater treatment program. Between 1989 and 2003, treated water from the LLNL site was routinely discharged to the recharge basin ponds. However, LLNL's program requirements changed during 2003, reducing the need to discharge water to the ponds. Although treated water has not been discharged to the ponds since July 2003, LLNL continues to maintain them as a backup location for discharge of treated water.

\subsubsection{Climate and Meteorology}

The climate at SNL/CA is typical of the Mediterranean conditions in the San Francisco Bay region where cool, wet winters and hot, dry summers are normal. In the summer, inland valleys, such as the Livermore Valley, generally experience more sunshine and higher temperatures than the coastal areas. In the winter, temperatures in the valley are usually cooler than at the coast.

Meteorological data for the SNL/CA area was obtained from a meteorological tower located approximately one mile north at LLNL. In past years, data was also obtained from a tower located onsite. However, the onsite tower was offline for several months during 2004 to replace the data instrumentation system. Consequently, onsite data is not included in the 
2004 statistics. The average annual rainfall near SNL/CA over the last five years was 11.83 inches. The annual rainfall for 2004 was 14.96 inches. Temperatures in 2004 ranged from $28^{\circ}$ to $101^{\circ}$ Fahrenheit. The windiest months in the area occur in the spring and summer, and are dominated by westerly sea breezes. The winds during the fall and winter are typically lighter and more varied in direction.

\subsubsection{Ecology}

The plant community at SNL/CA is typical of the surrounding region, consisting primarily of grassland. Localized areas of coyote brush scrub, willow riparian woodland, and aquatic habitat are also present. Areas developed and disturbed by Sandia operations constitute an additional habitat type, designated altered habitat. Habitat types are depicted on Figure 2-5. No threatened, endangered, proposed, or candidate plant species are present onsite.

A variety of wildlife species live and forage at SNL/CA. Since 1994, 76 bird species, 7 species of amphibians and reptiles, and 17 mammal species have been observed onsite. SNL/CA is also located within the range of the mountain lion (Puma concolor), a "specially protected mammal” under California law. Between July 2003 and April 2004, there were several unconfirmed mountain lion sightings on site. Passive monitoring at the site for visiting mountain lions is ongoing. SNL/CA uses the information obtained from monitoring to develop measures to increase personal safety for the site workforce and visitors.

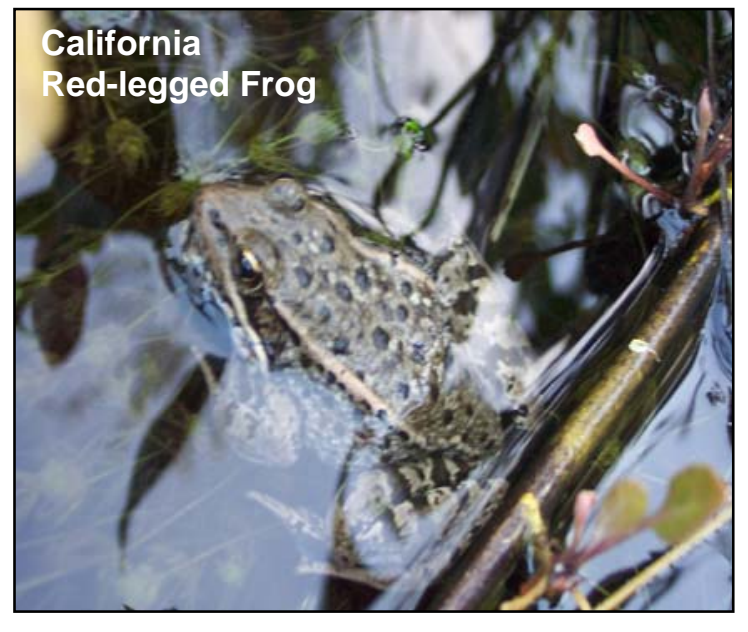

Two threatened wildlife species are present onsite, the California tiger salamander (Ambystoma californiense) and the California red-legged frog (Rana aurora draytonii). The most recent sighting of a tiger salamander at SNL/CA was on January 6, 2003, when one salamander was found in a shallow depression filled with leaf litter. The first confirmed observation of California red-legged frogs at SNL/CA occurred in April 2004 when several individuals were seen on the eastern portion of the site in shallow water contained within Arroyo Seco.

Most of the bird species found onsite during 2004 are protected under the Migratory Bird Treaty Act. Several of these are also special concern species. The Cooper's hawk (Accipiter cooperii) and sharp-shinned hawk (Accipiter striatus) are California species of special concern. The white-tailed kite (Elanus leucurus) and the golden eagle (Aquila chrysaetos) are California fully protected species. The loggerhead shrike (Lanius ludovicianus) and tricolored blackbird (Agelaus tricolor) are Federal birds of conservation concern and California species of special concern. Of these special concern species, the loggerhead shrike, whitetailed kite, and tri-colored blackbird are the only ones that were observed nesting at SNL/CA in 2004. The others are believed to be foraging on site but not nesting. 


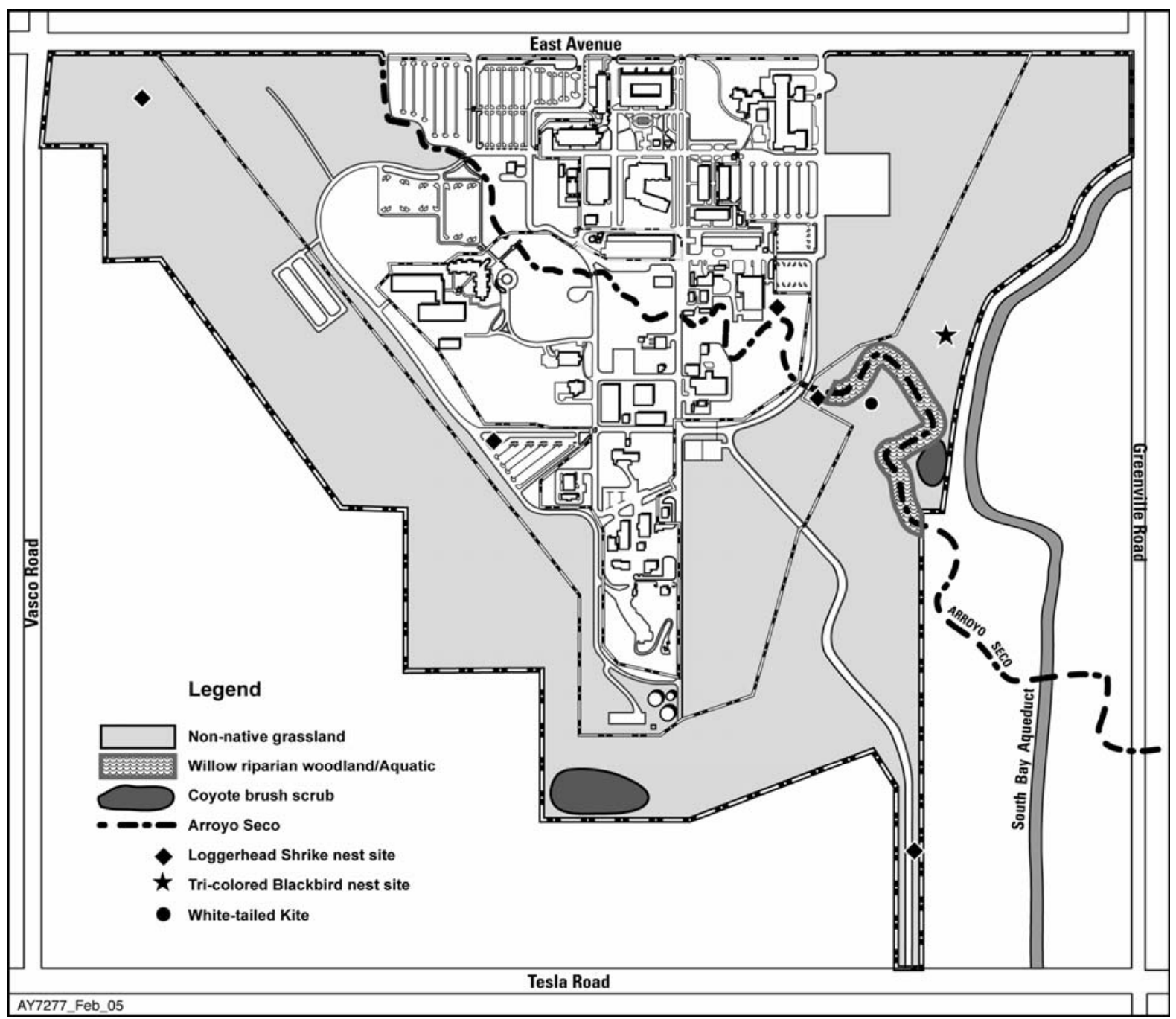

Figure 2-5 Wildlife and Habitat at SNL/CA, 2004 


\section{Compliance Summary}

Sandia National Laboratories, California (SNL/CA) operates in compliance with the letter and spirit of applicable federal, state, and local environmental laws and regulations. Additionally, as a Department of Energy (DOE) facility, the site is subject to DOE directives (DOE orders), and to presidential executive orders. This chapter provides a summary of SNL/CA compliance with major environmental requirements for the calendar year 2004.

\subsection{DOE Order 450.1}

DOE Order 450.1, Environmental Protection Program outlines the basic strategy for environmental compliance at DOE facilities, including SNL/CA. The objectives of Order 450.1 are to implement sound environmental stewardship practices, and to meet or exceed compliance with environmental, public health, and resource protection laws, regulations, and DOE requirements (DOE 2003b). The order requires DOE sites to meet these objectives through an environmental management system (EMS) that integrates environment, safety, and health into work planning and execution. Sandia has committed to implementing an institutionalized EMS by December 2005, the DOE established deadline. In 2004, SNL/CA established a site-specific EMS team to support corporate-wide EMS development and implementation. As part of this effort, the SNL/CA EMS team identified site-specific objectives and targets for use in measuring environmental consequences (positive and negative) of site operations. The SNL/CA team also began preparation of an EMS Program document to define the elements of the EMS program as they relate to the SNL/CA site, and to describe the mechanics of implementation on a site level. Additional information on the EMS program is provided in Chapter 4.

\subsection{National Environmental Policy Act}

The National Environmental Policy Act (NEPA) is the basic national charter for protection of the environment. It requires all federal agencies to evaluate the affects of major federal actions on the human environment, including the physical, socioeconomic, and cultural environments. NEPA review of DOE actions is conducted in accordance with DOE NEPA Implementing Procedures (10 CFR 1021). Under these procedures, DOE may prepare a programmatic (including site-wide) document at any time to further the purposes of NEPA. In 2003, the DOE/Sandia Site Office (DOE/SSO) issued a site-wide environmental assessment (SWEA) for continued operations at SNL/CA (DOE 2003a) and a Finding of No Significant Impact (FONSI) on March 20, 2003 (DOE 2003c). The SWEA evaluates the impacts of site operations over the next ten years, and the FONSI concludes that continuation of site operations is not a major federal action significantly affecting the quality of the human environment.

SNL/CA supports compliance with NEPA and DOE's NEPA Implementing Procedures by reviewing all new projects and programs or changes to existing projects and programs to ensure that they fit within the bounds of existing NEPA documents and impact analyses for the site. The SNL/CA NEPA review process is documented in an administrative procedure 
that is reviewed and updated every three years, or as needed. NEPA data for 2004 are provided in Section 4.3.1, Environmental Program Highlights.

\subsection{Air Quality}

\subsubsection{Clean Air Act}

The Clean Air Act (42 USC $\S 7401$ ) is the federal statute that forms the basis for the national air pollution control effort. It authorizes the Environmental Protection Agency (EPA) to promulgate air quality regulations and establishes national ambient air quality standards for criteria pollutants. Authority to implement the requirements of the Clean Air Act is provided to each state that has an EPA approved State Implementation Plan. The State Implementation Plan for California describes how National Ambient Air Quality Standards will be obtained in each air district. Each district establishes and enforces air pollution regulations to attain and maintain state and federal ambient air quality standards. The Bay Area Air Quality Management District (BAAQMD) is the regulating authority for controlling air pollution from stationary sources at SNL/CA. The California Air Resources Board (CARB) is responsible for ensuring that federal and state standards are met for mobile and small "area" sources of air pollution.

SNL/CA works with the BAAQMD and CARB to permit or register all regulated emission sources. In 2004, SNL/CA had 25 permitted emission sources (see Table 3-6, Section 3.14). Criteria pollutant and toxic air contaminant emissions from site operations are presented in Section 4.3.1, Table 4-1 and Table 4-2, respectively. Considering the type of activities conducted at this facility (small scale research and general maintenance), SNL/CA criteria and toxic emissions are likely to be a small portion of the Bay Area emissions. However, comparable Bay Area emission inventories are not available, particularly for toxic emissions. The latest BAAQMD toxic emission inventory available is based on 2002 data and would not serve as an accurate basis for comparison since the SNL/CA toxic emission data presented here is from the latest site-wide Permit to Operate (based on 2003 data). Also, emissions presented in the BAAQMD toxic emission inventory would likely be less than actual Bay Area emissions. For example, facilities that do not have sources permitted with the BAAQMD would likely not report any toxic emission data to BAAQMD. Even those facilities that have permitted sources and emit certain toxics, may not report such toxic emissions because they do not track such emissions, or they consider such emissions below reporting thresholds.

\subsubsection{Radionuclide Emissions}

The National Emissions Standards for Hazardous Air Pollutants, Subpart H - National Emission Standards for Emissions of Radionuclides Other Than Radon From Department of Energy Facilities (40 CFR Part 61) establishes radiation protection standards, monitoring requirements, and annual reporting of radionuclide air emissions. Additional requirements pertaining to radionuclide emissions are contained in DOE Order 450.1, Environmental Protection Program (DOE 2003b), and DOE Order 5400.5, Radiation Protection of the Public and the Environment (DOE 1993). 
SNL/CA does not currently have any radionuclide emission sources that are subject to the monitoring requirements of 40 CFR Part 61. To comply with national emission standards, SNL/CA evaluates individual projects with the potential to release radionuclide emissions to determine the worst-case dose to the public. Additionally, dose calculations are compared to the requirements to determine the need for annual monitoring. During 2004, there were no projects with the potential to release radionuclides to the atmosphere and thus no project evaluations were completed.

\subsection{Natural and Cultural Resources}

\subsubsection{Endangered Species Act}

The Endangered Species Act (16 USC § 1531 et. seq.) provides for protection of plant and wildlife species in danger of becoming extinct. In 2002, SNL/CA and DOE/SSO prepared the Biological Assessment for Continued Operation of Sandia National Laboratories, California (DOE 2002a). The biological assessment was submitted to the U.S. Fish and Wildlife Service (USFWS) on July 19, 2002. The document assesses possible effects that increased operations at the site would have on the threatened California red-legged frog (Rana aurora draytonii), proposed critical habitat for the red-legged frog ${ }^{1}$, and the threatened California tiger salamander (Ambystoma californiense). ${ }^{2}$ SNL/CA and DOE/SSO met with the USFWS on July 17, 2003 to discuss the biological assessment and future operations at the site. As a result of this meeting, an addendum to the biological assessment was prepared and submitted to the USFWS in December 2003.

On December 8, 2004, the USFWS issued a biological and conference opinion for continued operations at SNL/CA. The biological opinion concludes that proposed site operations are not likely to jeopardize the continued existence of the California red-legged frog and the California tiger salamander. The conference opinion concludes that site operations are not likely to destroy or adversely modify proposed critical habitat for the red-legged frog.

\subsubsection{Migratory Bird Treaty Act}

The Migratory Bird Treaty Act (16 USC $\S 703$ et. seq.) provides for protection of migratory birds, their nests, and eggs. Seventy-six species of migratory birds have been observed at SNL/CA since $1994^{3}$. In 2004, there was no intentional take of migratory birds or disturbance to nests or eggs at the site. Migratory birds often build nests within the developed campus in locations where they will be disturbed by maintenance activities. To avoid harming birds,

\footnotetext{
${ }^{1}$ On November 6, 2002, the U.S. District Court issued a final ruling overturning the critical habitat designation for the California red-legged frog (U.S. District Court 2002). The ruling approves a settlement between the U.S. Fish and Wildlife Service and the Home Builders Association of Northern California that eliminates all but 200,000 acres of the original four million acres designated. A proposed designation for critical habitat was reissued on April 13, 2004, and includes the Sandia site (USFWS 2004a).

${ }^{2}$ On August 4, 2004, the California tiger salamander was listed as threatened under the Endangered Species Act (USFWS 2004b).

${ }^{3}$ In 2004, a site-wide bird survey conducted at SNL/CA resulted in identifying additional bird species that had previously not been identified onsite. The number of migratory bird species observed since 1994 increased from 66 to 76.
} 
nests, or eggs, SNL/CA delays activities until the young have fledged, or surveys determine that the nest is abandoned. In 2004, five maintenance activities were delayed or modified to protect nesting birds.

\subsubsection{Floodplain Management}

Executive Order 11988, Floodplain Management (EO 11988), requires federal agencies to consider impacts associated with the occupancy and modification of floodplains, to reduce the risk of flood loss, to minimize the impact of floods on human safety, health, and welfare, and to restore and preserve the natural and beneficial values served by floodplains. In 2002, SNL/CA completed a management plan for the Arroyo Seco to identify channel improvements and stream zone management activities that will reduce flood and erosion risk and provide improved habitat for wildlife species that may use the arroyo (Matthews 2002). The plan identifies areas for constructing functional floodplains and for planting of native riparian vegetation. During 2004, one improvement task (rerouting of a sewer pipeline) was initiated. Activities associated with this one task and located within Arroyo Seco will be completed in 2006, after receipt of a permit from the U.S. Army Corp of Engineers.

\subsubsection{Protection of Wetlands}

Executive Order 11990, Protection of Wetlands (EO 11990), requires federal agencies to minimize the destruction, loss, or degradation of wetlands and preserve and enhance the natural and beneficial values of wetlands. A small wetland area of 0.44 acres is present at SNL/CA. During 2004, SNL/CA did not conduct any activities in the wetland area, or affecting wetlands.

\subsubsection{National Historic Preservation Act}

The National Historic Preservation Act (16 USC § 470) requires federal agencies to identify, record, and protect cultural resources. In 1990, an assessment of cultural resources at the SNL/CA site was completed. Although no prehistoric resources, Native American resources, or historic archaeological sites were identified during this assessment, there is a possibility that buried resources could be present on site (DOE 2003a). SNL/CA includes provisions for cultural resources in all construction-related contracts where the potential for buried resources may be unearthed. In 2004, there were no buried archaeological resources unearthed at SNL/CA.

In 2001, SNL/CA completed an historic building survey. None of the buildings onsite were identified as historically significant or eligible for the National Register of Historic Places (SNL 2002b). The results of the historic building survey were submitted to DOE/SSO. In December 2004, DOE transmitted the survey results to the California State Historic Preservation Officer for concurrence with the finding that there are no historic properties present at SNL/CA.

On September 22, 2004, DOE issued updated guidelines for developing cultural resource management plans (CRMP) for all DOE facilities (DOE 2004b). These guidelines are intended to assist each facility in meeting the statutory and regulatory requirements 
applicable to cultural resources. SNL/CA began preparing a site-specific CRMP in 2004. The CRMP will follow DOE guidance and address existing conditions at the site, the potential for discovery of buried resources, and the process for managing discovered resources. The SNL/CA CRMP is scheduled for completion in 2005.

\subsection{Environmental Restoration}

\subsubsection{Comprehensive Environmental Response, Compensation, and Liability Act}

Between 1984 and 1986, DOE investigated the SNL/CA site under their Comprehensive Environmental Assessment and Response Program (CEARP) to identify and assess potential environmental problems (DOE 1986). The CEARP investigation evaluated compliance with major federal environmental laws, including the Comprehensive Environmental Response, Compensation, and Liability Act (CERCLA) (42 USC § 9601). CERCLA established liability compensation, cleanup, and emergency response for hazardous substances released to the environment. During the CEARP investigation, two potential CERCLA sites were identified at SNL/CA, the Fuel Oil Spill Site and the Navy Landfill. A Hazard Ranking System study was performed for each site to determine if either qualified for listing on the National Priorities List. Hazard Ranking System scores for both sites fell below 28.5, the qualifying score for listing. Since completion of the CEARP investigation, there have been no hazardous substance releases or contaminated sites found at SNL/CA that warranted CERCLA investigation or a Hazard Ranking System study.

In addition to cleanup and emergency response requirements, CERCLA also established a program to report spills of hazardous substances to the National Response Center. SNL/CA incorporates CERCLA reporting requirements into an operating procedure for spill prevention and control (SNL/CA 2004b). In 2004, there were no releases of hazardous substances that required notification under CERCLA.

\subsubsection{Site Clean-up Orders}

Since 1985, environmental restoration and monitoring activities at SNL/CA have been conducted in compliance with site clean-up orders issued by the California Regional Water Quality Control Board, San Francisco Bay Region under provisions established in the California Water Code (California RWQCB 1989). Although there are no active remediation sites at SNL/CA, groundwater monitoring is ongoing at three locations, the Fuel Oil Spill site, the Navy Landfill, and the former Trudell Auto Repair Shop. SNL/CA currently samples four groundwater monitoring wells for residual contamination: two at the Fuel Oil Spill site; and one each at the Navy Landfill and Trudell site. Sampling results are presented in Chapter 5, Environmental Monitoring. 


\subsection{Hazardous Materials}

\subsubsection{Emergency Planning and Community Right-to-Know Act}

The Emergency Planning and Community Right-to-Know Act (EPCRA) — also known as the Superfund Amendments and Reauthorization Act of 1986, Title III (SARA Title III) (42 USC §11001, et. seq.) — requires reporting of toxic chemical usage and releases. To meet EPCRA requirements, SNL/CA submits annual reports to the EPA, the State of California, Alameda County of Environmental Health, and the LLNL Fire Department, which serves as the local fire department. EPCRA reporting requirements applicable to SNL/CA for 2004 are presented in Table 3-1.

Table 3-1 Status of EPCRA Reporting at SNL/CA, 2004

\begin{tabular}{llc}
\hline EPCRA Section & Description of Reporting & Required in 2004 \\
\hline Sec. 302-303 & Planning Notification & Yes \\
\hline Sec. 304 & Extremely Hazardous Substances Release Notification & No \\
\hline Sec. $311-312$ & Material Safety Data Sheet/ Chemical Inventory \\
\hline Sec. 313 & Toxic Release Inventory Reporting & Yes \\
\hline
\end{tabular}

\subsubsection{California Hazardous Materials Release Response Plans and Inventory Law}

The California Hazardous Materials Release Response Plans and Inventory Law (Assembly Bill 2185) addresses the management of hazardous and acutely hazardous materials in the state. Additional requirements pertaining to hazardous materials are codified in the California Health and Safety Code, Division 20, Chapter 6.95 §25500, et seq. In compliance with California requirements, SNL/CA annually submits a Hazardous Material Business Plan to the Alameda County Office of Environmental Health.

\subsubsection{Underground Storage Tanks}

Hazardous or petroleum products stored in underground storage tanks (UST) are regulated under California Health and Safety Code Division 20, Chapter 6.7, §§ 25280-25299.8.

California code incorporates the UST provisions of the Resource Conservation and Recovery Act (RCRA) and establishes standards for construction, operation, maintenance, inspection, and testing of USTs. Alameda County Environmental Health Department is the regulating authority for USTs at SNL/CA. SNL/CA operates one UST in accordance with California requirements. Each year, SNL/CA declares and permits the tank with the Alameda County Office of Environmental Health. This declaration is part of the Hazardous Material Business Plan described in Section 3.6.2. 


\subsubsection{Toxic Substances Control Act}

The Toxic Substances Control Act (TSCA) is the primary Federal statute regulating the manufacture, use, distribution, disposal, import, or export of certain chemicals and substances (15 USC $\S 2601$ et. seq.). TSCA requirements that are applicable to Sandia operations are incorporated into the Sandia ES\&H Manual (SNL 1997). SNL/CA follows the procedures outlined in the ES\&H Manual for import and export of chemical substances. In 2004, no TSCA regulated chemicals were imported to SNL/CA or exported from the site.

SNL/CA also tracks disposal of TSCA materials that are not otherwise captured as RCRA or California toxic hazardous waste. These materials include asbestos and polychlorinated biphenyls (PCBs). The majority of TSCA waste generated onsite is asbestos from abatement activities. Only small quantities of PCB wastes are generated at SNL/CA, consisting of light ballasts that are not specifically marked as PCB-free.

\subsubsection{Federal Insecticide, Fungicide, and Rodenticide Act}

The Federal Insecticide, Fungicide, and Rodenticide Act (FIFRA) restricts the registration, sale, use, and disposal of pesticides (includes herbicides, insecticides, fungicides, and rodenticides) (7 USC $\S 136$ ). Activities at SNL/CA that fall under the provisions of FIFRA include the storage and use of pesticides, and disposal of pesticide containers. Pesticide handling and storage follows a site-specific standard operating procedure that includes provisions for training, use of personal protective equipment, proper handling following manufacturers guidelines, secondary containment during storage, and disposal of product and containers (SNL/CA 2004c). Pesticide use at SNL/CA is overseen by a certified pesticide applicator.

\subsection{Pollution Prevention and Waste Minimization}

Pollution prevention concepts first appeared in RCRA. An expressed concern was to minimize the generation of hazardous waste through process substitution, materials recovery, recycling, reuse, and treatment. RCRA established the reduction or elimination of hazardous waste as national policy, and required that hazardous waste generators and RCRA permit holders have a program in place to minimize waste. SNL/CA is required to report waste generation and recycling information yearly to DOE. To meet this requirement, the Annual Waste Generation and Pollution Prevention Progress Report was submitted to DOE on November 24, 2004 (SNL/CA 2004d).

\subsubsection{Executive Order 13101}

Executive Order 13101, Greening the Government Through Waste Prevention, Recycling, and Federal Acquisition (EO 13101) directs executive agencies to implement affirmative procurement programs that favor acquisition and use of recycled products and environmentally preferable products and services. EO 13101 also establishes an annual reporting requirement for federal agencies. 
At SNL/CA, affirmative procurement is a coordinated effort between the Pollution Prevention and Waste Minimization (PP/WM) Program and the Procurement Department. The PP/WM staff communicates the requirements of EO 13101 through presentations and training targeting individuals involved in purchasing products and services. Both groups work closely with suppliers to ensure that environmentally preferable products are available for purchase.

In 1996, DOE established a goal for purchases of EPA designated recycled products of $100 \%$ by 2005, except where products are not commercially available competitively at a reasonable price, or do not meet performance standards. Of the products available for purchase by SNL/CA in 2004, 78.53\% qualified as designated recycled products. Affirmative procurement information for SNL/CA was electronically submitted to DOE on December 22, 2004 for use in the annual DOE environmentally preferable products report (DOE 2005).

\subsubsection{Hazardous Waste Source Reduction and Management Review Act}

The California Hazardous Waste Source Reduction and Management Review Act of 1989, (Senate Bill 14), requires hazardous waste generators to consider source reduction as the preferred method of managing hazardous waste. Under this act, facilities that generate more than 12,000 kilograms (kg) of hazardous waste or $12 \mathrm{~kg}$ of extremely hazardous waste annually are required to conduct source reduction planning.

Under this Act, all of DOE's California sites are considered one waste generator, rather than individual DOE facilities. Every four years, SNL/CA completes a Source Reduction and Evaluation Review and Plan in cooperation with the three other DOE sites in California: Lawrence Livermore National Laboratory (LLNL); Lawrence Berkeley National Laboratory; and Stanford Linear Accelerator Center. The most recent plan was completed in August 2003 and provides information for 1999 through 2002. The plan also identifies waste reduction opportunities for any waste stream that is over $5 \%$ of a site's total routine regulated waste.

\subsubsection{Pollution Prevention Act}

The Pollution Prevention Act of 1990 declares, as national policy, that pollution should be prevented or reduced at the source (42 USC § 13101 et. seq.). Facilities that meet the reporting requirements under EPCRA, Section 313 are also required to file a toxic chemical source reduction and recycling report. The Section 313 report for 2004 will include source reduction and recycling information to meet this requirement. See Section 3.6.1 for additional information on EPCRA.

\subsection{Hazardous Waste}

\subsubsection{Federal Facility Compliance Act}

The Federal Facility Compliance Act waives sovereign immunity with respect to RCRA for federal facilities (42 USC § 6961). The act gives EPA, and authorized states, authority to 
conduct annual inspections of federal facilities and establishes requirements for management of hazardous / mixed waste.

SNL/CA is not subject to a site-specific federal facility compliance agreement for mixed waste. The site does not possess or store any legacy mixed waste. All mixed waste generated at SNL/CA during 2004 was appropriately managed under the site's RCRA Hazardous Waste Facility Permit.

\subsubsection{Resource Conservation and Recovery Act}

RCRA regulates the generation, transportation, treatment, storage, and disposal of hazardous chemical waste, non-hazardous solid waste, and hazardous or petroleum products stored in USTs (42 USC $§ 6901$ et. seq.). The State of California has authority from the EPA to implement RCRA. The California Department of Toxic Substance Control (DTSC) administers most aspects of RCRA in the state, and is the regulating authority for hazardous waste operations at SNL/CA, including the hazardous component of radioactive mixed waste.

SNL/CA operates a Hazardous Waste Treatment and Storage Facility under a RCRA Hazardous Waste Facility Permit issued by DTSC on March 30, 2004. The permit is effective through March 2014 and allows for storage and treatment of hazardous waste.

By definition, SNL/CA is a large quantity generator of RCRA waste. As such, the site is required under RCRA standards and implementing regulations (40 CFR 262.41) to submit a biennial report to EPA. The last biennial report was submitted in March 2004 and provides information about the quantity of RCRA hazardous waste generated, stored, and shipped during the 2003 reporting period.

\subsubsection{California Hazardous Waste Control Law}

The Hazardous Waste Control Law (California Health and Safety Code §25100 et. seq.) provides a separate regulatory framework for hazardous waste management in California. The state law incorporates all RCRA requirements and imposes additional requirements that are stricter than RCRA standards. Under the California law, additional waste materials (e.g., oils, metals, asbestos, and solvents) are regulated as hazardous that are not considered hazardous under RCRA. State standards are incorporated into SNL/CA's Waste Management Program so that California regulated waste is managed as hazardous waste in compliance with state requirements.

The California Environmental Health Standard for Management of Hazardous Waste (22 CCR, Division 4.5) requires all permitted hazardous waste facilities to submit an annual facility report to DTSC. Annual facility reports provide information about the quantity of RCRA and California designated hazardous waste generated and stored at SNL/CA, and the quantity of waste shipped from the site. On March 1, 2005, the Annual Facility Report for the SNL/CA Hazardous Waste Treatment and Storage Facility was submitted to DTSC for the 2004 calendar year. 


\subsubsection{Medical Waste Management Act}

The California Medical Waste Management Act (California Health and Safety Code, Division 104, Part 14, §§ 117600-118360) provides for regulation of medical waste generators, transporters, and treatment facilities. The Alameda County Department of Environmental Health is the regulating authority for medical waste generated at SNL/CA. SNL/CA has two facilities identified as small quantity generators of medical waste, one with limited onsite treatment and one without onsite treatment.

\subsection{Radiation Protection}

\subsubsection{Atomic Energy Act}

The purpose of the Atomic Energy Act is to assure the proper management of nuclear materials and radioactive waste (42 USC § 2011 et. seq.). The act allows DOE to set radiation protection standards to control exposure to the public and the environment that may result from operations at DOE facilities. DOE sets these standards through department directives or orders. Operations at SNL/CA are subject to the requirements established in DOE Order 435.1, Radioactive Waste Management (DOE 2001b) and DOE Order 5400.5, Radiation Protection of the Public and the Environment (DOE 1993).

\subsubsection{DOE Order 435.1, Radioactive Waste Management}

DOE Order 435.1 establishes requirements to manage radioactive waste in a manner that protects the environment, and worker and public health and safety. Under this order, DOE contractor operated facilities are required to plan, document, execute, and evaluate the management of radioactive waste. Requirements of Order 435.1 are incorporated into the $\mathrm{SNL} / \mathrm{CA}$ radioactive waste management element of the Waste Management Program. The program includes certification and characterization of waste; provisions for inspections and audits; training requirements; and operating procedures for handling, storing, packaging, shipping, and offsite disposal of radioactive waste.

SNL/CA generates low-level radioactive waste and low-level mixed waste. No transuranic or high-level radioactive waste is generated by SNL/CA operations. Radioactive wastes are stored onsite in the Radioactive Waste Treatment and Storage Facility. Low-level waste is shipped offsite for land disposal at the Nevada Test Site. Low-level mixed waste is managed under RCRA and shipped offsite for disposal at commercial disposal sites in compliance with site-specific waste acceptance criteria.

\subsubsection{DOE Order 5400.5, Radiation Protection of the Public and the Environment}

DOE Order 5400.5 sets radiation protection standards for DOE operations so that radiation exposures to members of the public and the environment are as low as reasonably achievable (ALARA) and maintained within established limits of the order. Table 3-2 provides a summary of SNL/CA compliance with this order in 2004. 
Table 3-2 Order 5400.5 Compliance Summary, 2004

\begin{tabular}{|c|c|}
\hline Order 5400.5 Requirement & SNL/CA 2004 Summary \\
\hline $\begin{array}{l}\text { Maximum exposure to members of public }=100 \\
\mathrm{mrem} / \mathrm{yr}\end{array}$ & $\begin{array}{l}\text { There were no radionuclide emissions in } 2004 \text {. } \\
\text { The average annual gamma radiation } \\
\text { measurement at the site perimeter in } 2004 \text { was } 60 \\
\text { mrem, or } 3 \text { mrem more than distant locations, } \\
\text { where the average annual dose was } 57 \text { mrem. The } \\
\text { difference between perimeter and distant locations } \\
\text { is most likely the result of normal fluctuations and } \\
\text { natural variations in ambient radiation. }\end{array}$ \\
\hline Adopt ALARA exposures & $\begin{array}{l}\text { ALARA is incorporated into ES\&H policy, } \\
\text { ES\&H manual, and site operating procedures. }\end{array}$ \\
\hline $\begin{array}{l}\text { Control release of liquid radioactive wastes to the } \\
\text { environment }\end{array}$ & $\begin{array}{l}\text { No intentional discharges of liquid wastes to the } \\
\text { environment occur onsite. No accidental releases } \\
\text { of liquid radioactive waste occurred in } 2004 \text {. }\end{array}$ \\
\hline Control burial of low-level waste & $\begin{array}{l}\text { Disposal of low-level waste does not occur onsite. } \\
\text { ES\&H procedures, manuals, and management } \\
\text { systems are incorporated into site operations to } \\
\text { ensure proper handling, and disposal of } \\
\text { radioactive materials offsite at approved facilities. }\end{array}$ \\
\hline Control radioactive releases to the sanitary sewer & $\begin{array}{l}\text { Radioactive releases to the sanitary sewer above } \\
\text { DOE } 5400.5 \text { guidelines are not allowed at } \\
\text { SNL/CA. ES\&H procedures, manuals, and } \\
\text { management systems are incorporated into site } \\
\text { operations to ensure proper handling and disposal } \\
\text { of radioactive materials. }\end{array}$ \\
\hline $\begin{array}{l}\text { Implement environmental monitoring and } \\
\text { surveillance }\end{array}$ & $\begin{array}{l}\text { An environmental monitoring and surveillance } \\
\text { program has been in place at SNL/CA for more } \\
\text { than } 30 \text { years. }\end{array}$ \\
\hline $\begin{array}{l}\text { Control the release of property with residual } \\
\text { radioactivity }\end{array}$ & $\begin{array}{l}\text { SNL/CA does not release any property to the } \\
\text { public with residual radioactivity above } \\
\text { authorized limits. Excess property of this type is } \\
\text { either transferred to other DOE facilities for reuse } \\
\text { or transferred to Waste Management for disposal. }\end{array}$ \\
\hline NESHAPS Dose evaluations & $\begin{array}{l}\text { There were no airborne radionuclide emission } \\
\text { sources in 2004; therefore, there is no monitoring } \\
\text { data available for dose evaluations. }\end{array}$ \\
\hline
\end{tabular}

\subsection{Water Quality and Protection}

SNL/CA is subject to the requirements of the Clean Water Act and equivalent California statutes. SNL/CA is not currently subject to the requirements of the Safe Drinking Water Act, as the site does not operate a public water system. The site also is not involved in any environmental restoration activities for which Safe Drinking Water Act standards are being applied as clean-up goals.

Drinking water at SNL/CA is purchased through LLNL and obtained from the San Francisco Water District or the Alameda County Flood Control and Water Conservation District, Zone 7. The San Francisco Water District and Zone 7 are responsible for monitoring the quality of 
the incoming water. SNL/CA is not required to treat or sample the drinking water. LLNL maintains the drinking water distribution system for both sites and screens for water quality (SNL/CA 2002).

\subsubsection{Clean Water Act}

The Clean Water Act regulates all direct discharges into navigable waters of the United States (U.S.) (33 USC § 1251). Direct discharges to waters of the U.S. require permits issued under the National Pollutant Discharge Elimination System (NPDES). In California, the State Water Resources Control Board has authority from EPA to implement the Clean Water Act. Federal permitting requirements are included in Waste Discharge Requirements issued by Regional Water Quality Control Boards.

\section{Wastewater Discharge}

Wastewater generated at SNL/CA is discharged to the City of Livermore Water Reclamation Plant, a publicly owned treatment works (POTW). The Livermore POTW maintains an NPDES permit, and then regulates industry discharges into their sewer system. A Wastewater Discharge Permit issued by the Livermore POTW regulates SNL/CA's wastewater discharges. The permit is updated annually and includes discharge limits for the site sanitary sewer outfall and for processes subject to EPA pretreatment standards. Permit exceedances that occurred in 2004 at the site sanitary sewer outfall are presented in Table 3-3. See Section 3.13 for additional information regarding the July 24, 2004 copper exceedance.

Table 3-3 Wastewater Discharge Permit Exceedances at Sanitary Sewer Outfall, 2004

\begin{tabular}{lllllll}
\hline Parameter & $\begin{array}{l}\text { No. of } \\
\text { Samples } \\
\text { Taken }\end{array}$ & $\begin{array}{l}\text { No. of } \\
\text { Compliant } \\
\text { Samples }\end{array}$ & $\begin{array}{l}\text { Percent } \\
\text { Compliant }\end{array}$ & $\begin{array}{l}\text { Date(s) of } \\
\text { Exceedance }\end{array}$ & Description & Status / Resolution \\
\hline Copper & 52 & 51 & $98 \%$ & $7 / 24 / 2004$ & $\begin{array}{l}\text { Copper } \\
\text { concentration }\end{array}$ & $\begin{array}{l}\text { Probable source was } \\
\text { cooling tower cleaning } \\
\text { operation. New } \\
\text { cos } 4.0 \mathrm{mg} / \mathrm{L} .\end{array}$ \\
& & & & $\begin{array}{l}\text { Wischarge limit } \\
\text { cooling tower cleaning } \\
\text { process implemented. }\end{array}$ \\
\hline
\end{tabular}

SNL/CA has three categorical processes that are subject to EPA's pretreatment standards: two metal finishing operations, and a semiconductor manufacturing operation. ${ }^{4}$ One of the metal finishing operations is a closed-loop process and does not discharge any effluents. Wastewater generated from the two processes that have effluents is sampled and monitored as part of the Environmental Monitoring and Restoration Program. No exceedances of the discharge limits from these sources occurred during 2004.

\section{Storm Water Discharge}

General storm water discharges at SNL/CA are covered under the State of California NPDES General Permit for Storm Water Discharge Associated with Industrial Activities (General

\footnotetext{
${ }^{4}$ The semiconductor manufacturing operation is a research and development activity exempt from local air pollution regulations.
} 
Permit) (California Water Resources Control Board 1997). The General Permit requires SNL/CA to implement a storm water pollution prevention plan. The SNL/CA plan describes the rationale for monitoring discharge locations and identifies best management practices for reducing pollutant contact with storm water.

Storm water discharges from construction areas at SNL/CA are covered under the State of California NPDES General Permit for Storm Water Discharges Associated with Construction Activity (General Construction Permit) (California Water Resources Control Board 1999). During 2002, SNL/CA exceeded the five-acre threshold for construction activities, requiring the site to apply for coverage under the General Construction Permit. Coverage was granted on June 4, 2002 and extends through December 2006. In compliance with the General Construction Permit, SNL/CA implemented a construction activities storm water pollution prevention plan.

In 2004, twenty-two storm water discharge locations were visually monitored and eight locations were sampled. Samples were not collected from location Y in 2004, a ninth location that was sampled in 2003, due to insufficient water flow. The result of monitoring and sampling activities conducted in 2004 did not identify any issues of concern. A summary of results for 2004 is presented in Section 5.1.

\subsection{Executive Order 13148}

Executive Order 13148, Greening of the Government Through Leadership in Environmental Management (EO 13148), directs federal agencies to integrate environmental accountability into day-to-day decision making and long-term planning processes. Table 3-4 presents the activities conducted at SNL/CA in support of this executive order.

\subsection{Audits, Assessments, and Inspections}

Table 3-5 provides a list of environmental program audits, assessments, and/or inspections conducted at SNL/CA during 2004. 
Table 3-4 SNL/CA Activities in Support of Executive Order 13148

\begin{tabular}{|c|c|}
\hline E.O. 13148 Goal & SNL/CA Activity \\
\hline $\begin{array}{l}\text { Develop and implement environmental management } \\
\text { system }\end{array}$ & $\begin{array}{l}\text { Development of an Environmental } \\
\text { Management System began in 2004. Full } \\
\text { implementation is planned by December 31, } \\
2005 \text {. }\end{array}$ \\
\hline $\begin{array}{l}\text { Establish and implement environmental compliance audit } \\
\text { programs and policies that emphasize pollution prevention }\end{array}$ & $\begin{array}{l}\text { SNL/CA's ES\&H Interdisciplinary Team } \\
\text { process ensures that each new and modified } \\
\text { project is evaluated for pollution prevention } \\
\text { and waste minimization opportunities. } \\
\text { Additionally, SNL/CA maintains a PP/WM } \\
\text { Program that periodically conducts pollution } \\
\text { prevention opportunity assessments, and assists } \\
\text { site customers in implementing new processes } \\
\text { to reduce pollution and waste. }\end{array}$ \\
\hline EPCRA Reporting & Conducted annually. \\
\hline $\begin{array}{l}\text { Reduce EPCRA } 313 \text { reported Toxic Release Inventory } \\
\text { (TRI) releases and off-site transfers of toxic chemicals for } \\
\text { treatment and disposal }\end{array}$ & $\begin{array}{l}\text { SNL/CA meets the TRI reporting threshold for } \\
\text { lead only. Lead releases are generated from } \\
\text { activities at the firing range. To reduce TRI } \\
\text { releases, a change in ammunition type would } \\
\text { be required. Because DOE dictates the } \\
\text { ammunition type used at SNL/CA, any changes } \\
\text { would need to come from DOE. }\end{array}$ \\
\hline $\begin{array}{l}\text { Reduce use of toxic chemicals, hazardous substances, and } \\
\text { pollutants, or generation of hazardous and radioactive } \\
\text { waste types }\end{array}$ & $\begin{array}{l}\text { SNL/CA maintains a PP/WM Program to } \\
\text { identify waste minimization opportunities and } \\
\text { to assist site customers in implementing new } \\
\text { processes to reduce pollution and waste. }\end{array}$ \\
\hline Reduce use of ozone-depleting substances (ODS) & $\begin{array}{l}\text { SNL/CA complies with the regulations } \\
\text { contained in } 40 \text { CFR } 82 \text { that are designed to } \\
\text { end production of ODS, support recycling of } \\
\text { ODS during servicing and disposal, and } \\
\text { identify alternatives for ODS. }\end{array}$ \\
\hline $\begin{array}{l}\text { Promote sustainable management of federal lands through } \\
\text { cost-effective, environmentally sound landscaping } \\
\text { practices, and programs to reduce adverse impacts to the } \\
\text { natural environment }\end{array}$ & $\begin{array}{l}\text { Site landscaping practices follow the SNL/CA } \\
\text { Visual Quality Guidelines and Landscape } \\
\text { Master Plan that incorporates the use of } \\
\text { drought tolerant and native plant species into } \\
\text { landscape design. }\end{array}$ \\
\hline
\end{tabular}

\subsection{Environmental Occurrences}

SNL/CA had one environmental occurrence in 2004. On July 24, 2004, the site discharge limit for copper in the sanitary sewer was exceeded (see Table 3-3). Wastewater samples collected at the sewer outfall on July 24 showed a copper concentration of $4.0 \mathrm{mg} / \mathrm{L}$. The discharge limit for copper is $1.0 \mathrm{mg} / \mathrm{L}$. It was determined that a cooling tower cleaning operation caused the exceedance. In response to this exceedance, SNL/CA implemented a new cooling tower cleaning process that requires collecting all water from the cooling tower. The sediment in the water is allowed to settle, then the clean water is decanted into the sewer. The sediment is disposed of as solid waste. 
Table 3-5 SNL/CA Audits, Assessments, and Inspections, 2004

\begin{tabular}{|c|c|c|c|}
\hline Title & Area of Focus & Date Conducted & Results \\
\hline Alameda County Inspection & $\begin{array}{l}\text { Erosion at the Navy Landfill } \\
\text { site }\end{array}$ & September 15, 2004 & $\begin{array}{l}\text { Inspection only, no } \\
\text { issues }\end{array}$ \\
\hline \multirow[t]{2}{*}{$\begin{array}{l}\text { Bay Area Air Quality } \\
\text { Management District } \\
\text { Inspection }\end{array}$} & $\begin{array}{l}\text { Permitted and exempt } \\
\text { emission sources }\end{array}$ & June and July 2004 & $\begin{array}{l}\text { No areas of non- } \\
\text { compliance }\end{array}$ \\
\hline & Plating laboratory & & \\
\hline $\begin{array}{l}\text { City of Livermore, Water } \\
\text { Resources Division } \\
\text { Inspections }\end{array}$ & $\begin{array}{l}\text { Wastewater discharges and } \\
\text { categorical process } \\
\text { laboratories }\end{array}$ & $\begin{array}{l}\text { April 20, } 2004 \\
\text { September 14, } 2004\end{array}$ & $\begin{array}{l}\text { No areas of non- } \\
\text { compliance }\end{array}$ \\
\hline $\begin{array}{l}\text { National Nuclear Security } \\
\text { Administration, Nevada } \\
\text { Operations Audit } \\
\end{array}$ & $\begin{array}{l}\text { Nevada Radioactive Waste } \\
\text { Acceptance Program } \\
\text { compliance }\end{array}$ & March $1-5,2004$ & 2 corrective actions \\
\hline $\begin{array}{l}\text { California Department of } \\
\text { Toxic Substances Control } \\
\text { Audit } \\
\end{array}$ & $\begin{array}{l}\text { Hazardous waste } \\
\text { management and pollution } \\
\text { prevention activities }\end{array}$ & $\begin{array}{l}\text { January 21, } 2004 \text { and } \\
\text { October 29, } 2004 \\
\end{array}$ & $\begin{array}{l}\text { No findings or areas } \\
\text { on non-compliance }\end{array}$ \\
\hline $\begin{array}{l}\text { Alameda County } \\
\text { Environmental Health } \\
\text { Department }\end{array}$ & $\begin{array}{l}\text { Tiered permitting program } \\
\text { Medical waste handling }\end{array}$ & $\begin{array}{l}\text { May 27, } 2004 \\
\text { August 16, } 2004\end{array}$ & $\begin{array}{l}\text { No findings or areas } \\
\text { of non-compliance }\end{array}$ \\
\hline $\begin{array}{l}\text { Radioactive Waste } \\
\text { Management Program } \\
\text { Assessment (SNL/CA } \\
\text { internal) } \\
\end{array}$ & $\begin{array}{l}\text { Low-level radioactive waste } \\
\text { management }\end{array}$ & $\begin{array}{l}\text { February } 9-12 \text { and } \\
\text { November } 1-4,2004\end{array}$ & $\begin{array}{l}7 \text { findings and } 5 \\
\text { observations }\end{array}$ \\
\hline $\begin{array}{l}\text { Independent ES\&H and } \\
\text { Quality Assessment (SNL } \\
\text { corporate) }\end{array}$ & $\begin{array}{l}\text { Management systems, } \\
\text { documentation, and work } \\
\text { practices }\end{array}$ & $\begin{array}{l}\text { February and April } \\
2004\end{array}$ & $\begin{array}{l}11 \text { issues, } 7 \\
\text { observations, } 2 \\
\text { opportunities for } \\
\text { improvement, and } \\
\text { 11strengths }\end{array}$ \\
\hline $\begin{array}{l}\text { Waste Packaging and } \\
\text { Transportation Assessment } \\
\text { (SNL corporate) }\end{array}$ & $\begin{array}{l}\text { Hazardous waste packaging } \\
\text { and transportation activities }\end{array}$ & April 2004 & 1 observation \\
\hline $\begin{array}{l}\text { Independent Refrigerant } \\
\text { Program Assessment } \\
\text { (SNL/CA internal) }\end{array}$ & $\begin{array}{l}\text { Refrigerant management } \\
\text { activities }\end{array}$ & $\begin{array}{l}\text { February, March, and } \\
\text { September } 2004\end{array}$ & $\begin{array}{l}\text { General program } \\
\text { evaluation only }\end{array}$ \\
\hline $\begin{array}{l}\text { DOE Environmental Work } \\
\text { Processes Audit }\end{array}$ & $\begin{array}{l}\text { Waste packaging and } \\
\text { transportation, pollution } \\
\text { prevention, and wastewater / } \\
\text { storm water activities }\end{array}$ & $\begin{array}{l}\text { August and September } \\
2004\end{array}$ & $\begin{array}{l}3 \text { findings relating to } \\
\text { environmental } \\
\text { operations }\end{array}$ \\
\hline
\end{tabular}

\subsection{Permits}

Environmental permits and clean-up orders held by SNL/CA are listed in Table 3-6. Additional information is provided in previous sections under the relative program or regulation. 
Table 3-6 SNL/CA Environmental Permits and Orders, 2004

\begin{tabular}{|c|c|c|c|c|}
\hline Type & Description & Effective Date & $\begin{array}{l}\text { Statute / } \\
\text { Regulation }\end{array}$ & Issuing Agency \\
\hline \multirow[t]{8}{*}{ Air } & $\begin{array}{l}\text { Permit to Operate } 25 \text { emission } \\
\text { sources: }\end{array}$ & \multirow{8}{*}{$\begin{array}{l}\text { July 1, } 2004 \\
\text { through June 30, } \\
2005\end{array}$} & \multirow[t]{8}{*}{ Clean Air Act } & \multirow{8}{*}{$\begin{array}{l}\text { Bay Area Air } \\
\text { Quality } \\
\text { Management } \\
\text { District }\end{array}$} \\
\hline & 10 Boilers & & & \\
\hline & 1 Degreaser & & & \\
\hline & 1 Paint spray booth & & & \\
\hline & $\begin{array}{l}1 \text { Non-retail gasoline } \\
\text { dispensing facility }\end{array}$ & & & \\
\hline & $\begin{array}{l}1 \text { Chromium electroplating } \\
\text { operation }\end{array}$ & & & \\
\hline & $\begin{array}{l}5 \text { Miscellaneous } \\
\text { (decontamination sink, waste } \\
\text { compactor, drum crusher, two } \\
\text { sitewide sources for solvent } \\
\text { emissions) }\end{array}$ & & & \\
\hline & 6 Emergency generators & & & \\
\hline $\begin{array}{l}\text { Environmental } \\
\text { restoration }\end{array}$ & $\begin{array}{l}\text { Site Clean-up Order No. 89- } \\
184\end{array}$ & $\begin{array}{l}\text { December } 1989 \\
\text { (no expiration date) }\end{array}$ & $\begin{array}{l}\text { California Water } \\
\text { Code }\end{array}$ & $\begin{array}{l}\text { Regional Water } \\
\text { Quality Control } \\
\text { Board, San } \\
\text { Francisco Bay } \\
\end{array}$ \\
\hline Hazardous waste & $\begin{array}{l}\text { RCRA Hazardous Waste } \\
\text { Facility Permit }\end{array}$ & $\begin{array}{l}\text { March } 2004 \\
\text { through March } \\
2014\end{array}$ & $\begin{array}{l}\text { Resource } \\
\text { Conservation and } \\
\text { Recovery Act }\end{array}$ & $\begin{array}{l}\text { California } \\
\text { Department of } \\
\text { Toxic Substances } \\
\text { Control }\end{array}$ \\
\hline Medical waste & $\begin{array}{l}\text { Small Quantity Generator } \\
\text { with Onsite Treatment }\end{array}$ & $\begin{array}{l}\text { August 9, } 2004 \\
\text { through August 8, } \\
2005\end{array}$ & $\begin{array}{l}\text { California Health and } \\
\text { Safety Code }\end{array}$ & $\begin{array}{l}\text { Alameda County } \\
\text { Environmental } \\
\text { Health Department }\end{array}$ \\
\hline Medical waste & $\begin{array}{l}\text { Small Quantity Generator } \\
\text { without Onsite Treatment }\end{array}$ & $\begin{array}{l}\text { April 11, } 2004 \\
\text { through April 10, } \\
2005\end{array}$ & $\begin{array}{l}\text { California Health and } \\
\text { Safety Code }\end{array}$ & $\begin{array}{l}\text { Alameda County } \\
\text { Environmental } \\
\text { Health Department }\end{array}$ \\
\hline Wastewater & Wastewater Discharge Permit & $\begin{array}{l}\text { August } 2004 \\
\text { through July } 2005\end{array}$ & Clean Water Act & $\begin{array}{l}\text { City of Livermore } \\
\text { Water Reclamation } \\
\text { Plant }\end{array}$ \\
\hline Storm water & $\begin{array}{l}\text { State of California General } \\
\text { Industrial Permit }\end{array}$ & $\begin{array}{l}\text { July } 1997 \text { through } \\
\text { July } 2002^{\text {a }}\end{array}$ & Clean Water Act & $\begin{array}{l}\text { State of California } \\
\text { Water Resources } \\
\text { Control Board }\end{array}$ \\
\hline Storm water & $\begin{array}{l}\text { State of California } \\
\text { Construction Activities } \\
\text { General Permit }\end{array}$ & $\begin{array}{l}\text { June } 2002 \text { through } \\
\text { December } 2006\end{array}$ & Clean Water Act & $\begin{array}{l}\text { State of California } \\
\text { Water Resources } \\
\text { Control Board } \\
\end{array}$ \\
\hline $\begin{array}{l}\text { Underground } \\
\text { storage tank }\end{array}$ & Permit to Operate & $\begin{array}{l}\text { March 1, } 2004 \\
\text { through February } \\
28,2005\end{array}$ & $\begin{array}{l}\text { Resource } \\
\text { Conservation and } \\
\text { Recovery Act and } \\
\text { California Health and } \\
\text { Safety Code }\end{array}$ & $\begin{array}{l}\text { Alameda County } \\
\text { Environmental } \\
\text { Health Department }\end{array}$ \\
\hline $\begin{array}{l}\text { Aboveground } \\
\text { storage tanks }\end{array}$ & Storage statement & $\begin{array}{l}\text { July 1, } 2004 \\
\text { through June 30, } \\
2006\end{array}$ & $\begin{array}{l}\text { Aboveground } \\
\text { Petroleum Storage } \\
\text { Act }\end{array}$ & $\begin{array}{l}\text { State of California } \\
\text { Water Resources } \\
\text { Control Board }\end{array}$ \\
\hline
\end{tabular}




\section{Environmental Program Information}

Sandia National Laboratories, California (SNL/CA) achieves environmental compliance through implementation of various environment, safety, and health (ES\&H) policies and principles. This chapter describes the environmental management structure at SNL/CA and presents environmental performance measurements for 2004. SNL/CA environmental programs are also identified and 2004 highlights for each program are provided.

\subsection{Environmental Management}

Historically, environmental management at Sandia National Laboratories (SNL) focused on a requirements-driven program that mandated compliance with environmental laws, regulations, Department of Energy (DOE) directives, and internal policies. As a result, SNL has a well-defined ES\&H program that addresses all aspects of the environmental regulatory arena. Corporate policies, an ES\&H compliance manual, environmental programs, and ES\&H councils, committees, and teams support environmental management at Sandia.

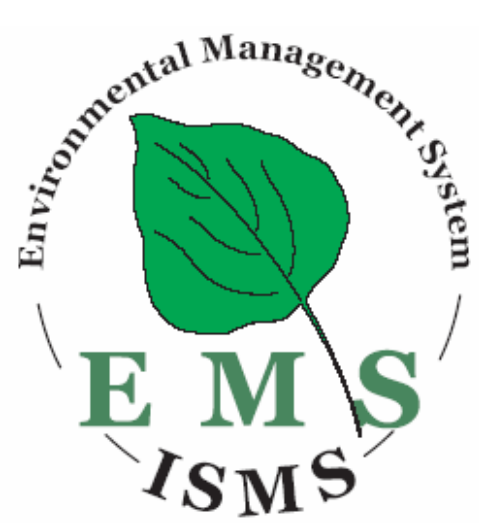

Over the past few years, Sandia's focus has shifted from a compliance-based program to a program that looks beyond compliance towards stewardship. Planning and implementation of a comprehensive program, or environmental management system (EMS), is underway. The corporate EMS aligns with the integrated safety management system (ISMS) that incorporates five core principles into Sandia operations: work planning; analysis of the hazards; development and implementation of hazard controls; performance of work within established controls; and provision of feedback for continuous improvement.

This continuing cycle of planning, implementing, evaluating, and improving processes and actions is implemented through Sandia's EMS such that potential adverse environmental effects are reduced and environmental stewardship is enhanced. SNL/CA maintains a sitespecific EMS that tiers from the corporate program but is tailored to the environmental risks applicable to California operations.

As part of the EMS process, SNL/CA completed a risk analysis in 2004 to identify and prioritize potential environmental risk areas. Information derived from the risk analysis also assisted in identifying opportunity areas with a high potential for enhancing environmental stewardship. SNL/CA established long-term objectives and targets for the top five environmental risk areas and top five opportunity areas. Activities to support and achieve site objectives will be initiated in 2005. 


\subsection{Environmental Performance}

In 2003, Sandia established stringent goals for environmental performance and incorporated these goals into the EMS/ISMS as ES\&H Performance Excellence Objectives. The Sandia workforce routinely applies these objectives to all work activities at SNL/CA. During 2004, the site had one notice of violation (for the copper exceedance in the sanitary sewer), and zero environmental fines or penalties.

The DOE, National Nuclear Security Administration also evaluates environmental performance at Sandia in accordance with an annual performance evaluation plan. The evaluation plan is a jointly negotiated document that defines specific performance objectives, performance measures, and performance criteria. Each performance measure is assigned a numerical score that corresponds to one of four ratings: outstanding; good; satisfactory; and unsatisfactory.

The fiscal year 2004 Performance Evaluation Plan measures two performance groups, (1) mission programs, and (2) operations. Environmental performance is included in the operations performance group. The overall rating for this performance group for fiscal year 2004 is "good."

\subsection{Environmental Programs}

SNL/CA maintains an Environmental Operations Department that is comprised of six functional program areas. Program areas and primary elements of each are as follows:

> Air Quality - air emissions source evaluation, permitting, and permitting compliance.

$>$ Environmental Monitoring and Restoration - wastewater, storm water, and groundwater monitoring for radiological and non-radiological constituents; ambient surveillance for external radiation exposures; environmental restoration and remediation; and radionuclide air emission compliance

> Environmental Planning - National Environmental Policy Act (NEPA) reviews; ecological resource management; cultural and historic resource reviews; and general environmental reporting

> Hazardous Materials Management - hazardous materials (biological and chemical) inventory and Material Safety Data Sheet (MSDS) management; Emergency Planning and Community Right-to-Know Act and California Right-to-Know regulation compliance and reporting; and supports chemical safety activities sitewide

$>$ Pollution Prevention and Waste Minimization - pollution prevention opportunity assessments; recycling programs; supports site-wide waste reduction; and supports affirmative procurement program 
> Waste Management - hazardous, radioactive, and mixed waste management; Resource Conservation and Recovery Act (RCRA) permitting; and operation of onsite waste treatment and storage facilities

\subsubsection{Environmental Program Highlights}

\section{Air Quality Program}

In 2004, SNL/CA permitted 25 emission sources with the Bay Area Air Quality Management District (BAAQMD), the same number as were permitted in 2003. The number of permitted sources has decreased since 1996 when SNL/CA operated 29 permitted sources. The number of sources listed as exempt on the SNL/CA BAAQMD Permit to Operate has decreased from 34 in 1996 to 11 in 2004. Emission rates from the 2004 permitted sources are presented in Tables 4-1 and 4-2.

During 2004, the BAAQMD conducted an inspection of 26 of the 34 permitted and exempt sources at SNL/CA. All 26 sources were found to be in full compliance with regulatory requirements and permit conditions. Also during 2004, the Air Quality Program was evaluated during a Sandia corporate assessment on ES\&H and quality. The Program's proactive approach to tracking emission data to identify when operations are nearing maximum allowable permit conditions was noted as a site strength.

Table 4-1 Criteria Pollutant Emission Rates at SNL/CA

\begin{tabular}{lc}
\hline Pollutant & $\begin{array}{c}\text { SNL/CA 2004 Emissions } \\
(\mathbf{k g} / \mathbf{y r})^{\mathbf{a}}\end{array}$ \\
\hline Particulates & 830 \\
\hline Organic compounds & 3000 \\
\hline Nitrogen oxides & 3500 \\
\hline Sulfur dioxide & 30 \\
\hline Carbon monoxide & 620 \\
\hline annual emissions were calculated by multiplying the daily emissions reported in the BAAQMD \\
Permit to Operate (expires July 1, 2005) by 365. Emissions for 2004 permitted sources are based on \\
2003 data.
\end{tabular}


Table 4-2 Toxic Emission Rates at SNL/CA

\begin{tabular}{lc}
\hline Pollutant & $\begin{array}{c}\text { SNL/CA 2004 Emissions } \\
(\mathbf{k g} / \mathbf{y r})^{\mathbf{a}}\end{array}$ \\
\hline Ethylene dichloride & 3 \\
\hline Formaldehyde & 8 \\
\hline Methyl ethyl ketone & 18 \\
\hline Methyl alcohol & 708 \\
\hline Perchloroethylene & 83 \\
\hline Toluene & 20 \\
\hline 1,4-Dioxane & 12 \\
\hline Xylene & 10 \\
\hline Chloroform & 28 \\
\hline Mehtylene chloride & 131 \\
\hline Bromine & 2 \\
\hline 1,1,1-Trichloroethane & 13 \\
\hline Hydrochloric acid mist & 25 \\
\hline Annual emissions were calculated by multiplying the daily emissions reported in the \\
$\begin{array}{l}\text { BAAQMD Permit to Operate (expires July 1, 2005) by 365. Emissions for 2004 permitted } \\
\text { sources are based on 2003 data. }\end{array}$ \\
\hline
\end{tabular}

\section{Environmental Monitoring and Restoration Program}

The Environmental Monitoring and Restoration Program continued efforts during 2004 to monitor copper in the sanitary sewer. A new satellite sewer monitoring system, put into place after a 2003 copper exceedance, was proven a successful tool to quickly identify potential sources of copper in the sanitary sewer. Within hours after receipt of analytical results that showed a copper exceedance on July 24, 2004 (see Section 3.13), the source of the copper was determined. SNL/CA was able to initiate corrective actions quickly to avoid recurrence.

In 2003, new state regulations were issued for municipal small separate storm sewers. In response to these new regulations, SNL/CA developed a Stormwater Pollution Prevention Plan to address the three types of stormwater regulation applicable to the site (i.e., industrial, construction, and municipal). Although the new regulations are not yet in effect for SNL/CA operations, the Environmental Monitoring and Restoration Program continued to prepare and to work proactively to meet the new requirements. In 2004, a new storm drain maintenance program was established and efforts began to incorporate post-construction runoff controls into site design and operations.

Routine compliance and monitoring activities conducted by the Environmental Monitoring and Restoration Program are presented in Chapter 3 and 5, respectively.

\section{Environmental Planning Program}

During 2004, the Environmental Planning Program continued the site education efforts on wildlife issues through establishment of a wildlife website. The website provides information 
on site requirements, a photo gallery, a summary of survey activities, information on individual species, and downloadable information posters.

In fiscal year 2004, Environmental Planning staff reviewed 195 actions in accordance with the SNL/CA NEPA Administrative Procedure (SNL/CA 2004a), a 59 percent increase from fiscal year 2003. Of these, 189 actions were covered under existing NEPA documentation and six were referred to DOE for NEPA determinations. All six actions referred to DOE were categorically excluded from the need to prepare an environmental assessment or environmental impact statement.

For calendar year 2004, actual site operations were compared to the maximum operations scenario presented in the SWEA and an evaluation was made to determine whether SNL/CA operations remain within the impact analysis presented. Table 4-3 presents a summary of the comparison and evaluation results.

\section{Hazardous Materials Management Program}

During 2004, the Hazardous Materials Management Program completed a multi-year redevelopment of the Chemical Information System (CIS). Launched corporate-wide on December 13, 2004, the redeveloped CIS integrates with ES\&H and other general corporate business systems for enhanced system performance. New tools available in the CIS allow improvements in customer ease-of-use, accuracy of hazardous materials inventory, efficiency of regulatory reporting, and availability of MSDS information.

Each year, the Hazardous Materials Management Program conducts annual hazardous material inventory reconciliation. In 2004, the reconciliation team achieved a 92 percent "found rate," the highest achieved since reconciliation began ten years ago. The team surpassed the corporate performance target of 90 percent.

Efforts to reduce the hazardous material inventory at SNL/CA began in the fall of 2004 in response to concerns about site housekeeping. The site established a goal of ten percent reduction in the number of hazardous material containers tracked through the CIS by October 2005. By the end of 2004, the site showed progress in meeting this goal by reducing the inventory 2.5 percent.

\section{Pollution Prevention and Waste Minimization Program}

The Pollution Prevention and Waste Minimization Program implemented three new recycling programs at SNL/CA in 2004 for paper, fire extinguishers, and empty chemical containers. These new programs resulted in a 283 percent increase in paper recycling, collection of 272 kilograms of fire extinguishers for reuse, and redirection of 449 kilograms of empty containers from hazardous waste disposal to recycling. Recycling of empty containers represents a disposal cost savings of $\$ 4,990$. 
Table 4-3 Comparison of 2004 Operations with SWEA Envelope

\begin{tabular}{|c|c|c|c|}
\hline Activity / Unit & $\begin{array}{l}\text { SWEA Envelope (maximum } \\
\text { operations) }\end{array}$ & Calendar Year 2004 & $\begin{array}{l}\text { Site Operations Remain } \\
\text { Within Impact Analysis }\end{array}$ \\
\hline \multicolumn{4}{|l|}{ Proposed Action } \\
\hline Site mission & Supports DOE, NNSA, DHS & No change & Yes \\
\hline $\begin{array}{l}\text { Arroyo Seco } \\
\text { improvements }\end{array}$ & 20 tasks over ten years & $\begin{array}{l}\text { One task initiated as of } \\
\text { December 31, } 2004\end{array}$ & Yes \\
\hline Increase operations & Increase to 2 shifts & 1 shift & Yes \\
\hline New facilities & $\begin{array}{l}5,000 \text { sf badge office; new } \\
16,000 \text { sf laboratory; } 84,000 \text { sf } \\
\text { laboratory replacement for } \\
\text { Building } 916\end{array}$ & $\begin{array}{l}\text { None completed in } \\
2004\end{array}$ & Yes \\
\hline Demolition & 100,000 sf over ten years & $1,656 \mathrm{sf}$ & Yes \\
\hline \multicolumn{4}{|l|}{ Land Use } \\
\hline Construction area & 93 acres over ten years & $\begin{array}{l}8 \text { acres as of December } \\
31,2004\end{array}$ & Yes \\
\hline Wildlife reserve & 30 acres over ten years & 106 acres & $\begin{array}{l}\text { Yes - results in a positive } \\
\text { effect }\end{array}$ \\
\hline \multicolumn{4}{|l|}{ Geology / Soil } \\
\hline $\begin{array}{l}\text { Solid waste } \\
\text { management units }\end{array}$ & 23 units total & 22 units & Yes \\
\hline Soil removed & $5000 \mathrm{cu} \mathrm{yd} / \mathrm{yr}$ & $0 \mathrm{cu}$ yd & Yes \\
\hline Soil managed onsite & $5000 \mathrm{cu} \mathrm{yd} / \mathrm{yr}$ & $<1000 \mathrm{cu}$ yd & Yes \\
\hline $\begin{array}{l}\text { Backfill material } \\
\text { brought onsite }\end{array}$ & $6000 \mathrm{cu} \mathrm{yd} / \mathrm{yr}$ & $<1000 \mathrm{cu} \mathrm{yd}$ & Yes \\
\hline \multicolumn{4}{|l|}{ Infrastructure } \\
\hline Water use & $91.8 \mathrm{million} \mathrm{gal} / \mathrm{yr}$ & 95.8 million gals & $\begin{array}{l}\text { Yes - Although, water use } \\
\text { was higher than projected, } \\
\text { SNL/CA did not exceed the } \\
\text { capacity of the water } \\
\text { distribution system; an } \\
\text { additional impact did not } \\
\text { occur. }\end{array}$ \\
\hline $\begin{array}{l}\text { Sanitary sewer } \\
\text { discharge }\end{array}$ & $29.1 \mathrm{million}$ gal/yr & 12.1 million gals & Yes \\
\hline Natural gas use & 94 million $\mathrm{cu} \mathrm{ft} / \mathrm{yr}$ & 65.7 million $\mathrm{cu} f t$ & Yes \\
\hline Electricity use & $48,800 \mathrm{MW} \mathrm{h} / \mathrm{yr}$ & 38,589 MW hrs & Yes \\
\hline \multicolumn{4}{|l|}{$\begin{array}{l}\text { Biological and Ecological } \\
\text { Resources }\end{array}$} \\
\hline $\begin{array}{l}\text { Construct flood plains } \\
\text { in Arroyo Seco }\end{array}$ & 1800 linear feet over ten years & None & Yes \\
\hline Create riparian habitat & 0.2 acres over ten years & None & Yes \\
\hline $\begin{array}{l}\text { Ground disturbance in / } \\
\text { along arroyo }\end{array}$ & 10 acres over ten years & None & Yes \\
\hline Cultural Resources & None known onsite & No change & Yes \\
\hline \multicolumn{4}{|l|}{ Water Resources } \\
\hline Impervious surface area & 76.9 acres total & 54.1 acres & Yes \\
\hline Irrigation water use & 17 million gal/yr & 16.6 million gals & Yes \\
\hline \multicolumn{4}{|l|}{ Waste Generation } \\
\hline Radioactive waste & $8,811 \mathrm{~kg} / \mathrm{yr}$ & $3,094 \mathrm{~kg}$ & Yes \\
\hline Hazardous waste & $133,820 \mathrm{~kg} / \mathrm{yr}$ & $85,318 \mathrm{~kg}$ & Yes \\
\hline Construction debris & 200 tons/yr & 0 & Yes \\
\hline $\begin{array}{l}\text { Solid waste (non- } \\
\text { hazardous) }\end{array}$ & 378.7 metric tons/yr & 131.9 metric tons & Yes \\
\hline
\end{tabular}


Table 4-3 Comparison of 2004 Operations with SWEA Envelope (continued)

\begin{tabular}{|c|c|c|c|}
\hline Activity / Unit & $\begin{array}{l}\text { SWEA Envelope (maximum } \\
\text { operations) }\end{array}$ & Calendar Year 2004 & $\begin{array}{l}\text { Site Operations Remain } \\
\text { Within Impact Analysis }\end{array}$ \\
\hline \multicolumn{4}{|l|}{ Proposed Action } \\
\hline \multicolumn{4}{|l|}{ Air Emissions } \\
\hline Total criteria pollutants & $8,212 \mathrm{~kg} / \mathrm{yr}$ & $7,500 \mathrm{~kg}^{\mathrm{a}}$ & Yes \\
\hline Total air toxics & $2,880.16 \mathrm{~kg} / \mathrm{yr}$ & $1,100 \mathrm{~kg}^{\mathrm{a}}$ & Yes \\
\hline Radioactive & 0 emissions & 0 emissions & Yes \\
\hline Permits & 57 permits annually & 25 permits & Yes \\
\hline \multicolumn{4}{|l|}{ Human Health } \\
\hline $\begin{array}{l}\text { Recordable accidents / } \\
\text { injuries }\end{array}$ & 78 accidents / injuries annually & 21 accident / injuries & Yes \\
\hline Lost work-day cases & 19 days annually ${ }^{\mathrm{b}}$ & 2 days & Yes \\
\hline \multicolumn{4}{|l|}{ Socioeconomics } \\
\hline Employment & Up to 1931 persons annually & 1094 persons & Yes \\
\hline Operating budget & $\$ 262$ million/yr & 219.2 million & Yes \\
\hline
\end{tabular}

In 2004, SNL/CA recycled 225.92 metric tons of material, excluding yard waste. Table 4-4 presents the quantity of each item recycled during the year. Figure 4-1 depicts total quantity of materials recycled annually since 1999 (excludes yard waste). As shown, the quantity of materials recycled at SNL/CA increased in 2004 compared to previous years. The change is primarily due to paper and scrap metal recycling.

Table 4-4 SNL/CA Recycling Data, 2004

\begin{tabular}{llll}
\hline Recycled Item & $\begin{array}{l}\text { Quantity Recycled } \\
\text { (metric tons) }\end{array}$ & Recycled Item & $\begin{array}{l}\text { Quantity Recycled } \\
\text { (metric tons) }\end{array}$ \\
\hline Aluminum cans & 0.32 & Cardboard & 14.34 \\
\hline Light tubes & 1.79 & Computer monitors & 13.74 \\
\hline Paper & 56.56 & Scrap metals & 83.27 \\
\hline Tires & 0 & Toner cartridges & 0.99 \\
\hline Precious Metals & 0.01 & Wood & 30.25 \\
\hline Batteries & 2.0 & Engine oils & 1.67 \\
\hline Freon & 0.03 & Metal drums & 0 \\
\hline Oil filters & 0.22 & Empty containers & 0.48 \\
\hline Mercury & 0.01 & Resins and bottles & 4.11 \\
\hline Carpet tile & 3.31 & Cylinders & 0.26 \\
\hline Fire extinguishers & 0.27 & Mixed recycled load & 12.29 \\
\hline
\end{tabular}

\section{Waste Management Program}

During 2004, the Waste Management Program continued with characterization of site-wide legacy radioactive sources having no further use. All sources are characterized for safe onsite storage and accountability, and are undergoing final characterization to meet Nevada Test Site disposal requirements. Packaging and disposal of items characterized during 2004 are expected to occur in spring 2005. 


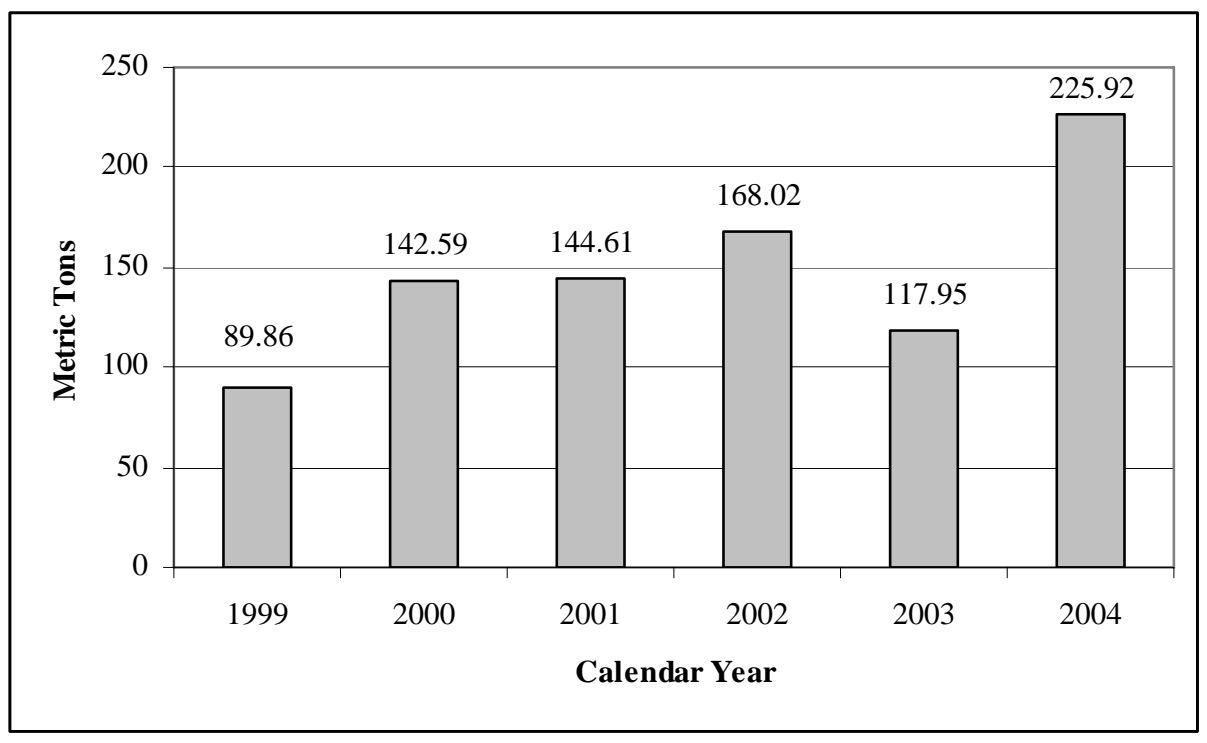

Figure 4-1 Total Recycled Materials at SNL/CA, 1999 to 2004

The Waste Management Program tracks and maintains a database of radioactive and hazardous waste generated at SNL/CA. Table 4-5 presents waste generation data for 2004 . Data for 2003 is also included for comparison. As shown, SNL/CA experienced an increase in California toxic (non-RCRA) and Toxic Substances Control Act (TSCA)-regulated waste streams during 2004. The increase in non-RCRA waste is attributed to the chemical inventory reduction effort addressed under the Hazardous Materials Management Program (page 4-5). The increase in TSCA waste resulted from building modification and renovation projects conducted during the year that generated asbestos flooring and roofing debris. Although not tracked by the Waste Management Program, sanitary waste is also shown.

Table 4-5 Waste Generated at SNL/CA, 2003 and 2004

\begin{tabular}{lcccc}
\hline Waste Type & $\mathbf{2 0 0 3} \mathbf{( k g )}$ & $\mathbf{2 0 0 4}(\mathbf{k g})$ & Change (kg) & Percent Change \\
\hline RCRA & 22,149 & 18,147 & $-4,002$ & -18 \\
\hline California toxic (non-RCRA) & 29,154 & 48,066 & 18,912 & 65 \\
\hline TSCA regulated & 5,159 & 19,105 & 13,946 & 270 \\
\hline Biohazardous & 43 & 64 & 21 & 49 \\
\hline Low-level radioactive & 13693 & 3,094 & $-10,600$ & -77 \\
\hline Low-level mixed & 60 & 0 & -60 & -100 \\
\hline Sanitary & 100,250 & 131,940 & 31,690 & 32
\end{tabular}




\section{Environmental Monitoring}

Sandia National Laboratories, California (SNL/CA) monitors storm water, wastewater, groundwater, and gamma radiation. This chapter provides a summary of monitoring activities and results for each of these media. Both radiological and non-radiological data are presented.

SNL/CA does not directly monitor airborne effluents. Non-radiological (chemical) emission sources do not require routine or continuous monitoring of ambient air quality concentrations. However, SNL/CA does maintain equipment and process usage records (e.g. hours of operation or quantity of solvents used) for emission sources. Similarly, there are no radionuclide emission sources that require routine monitoring. SNL/CA maintains an inventory of radioactive isotopes (small quantity sealed and unsealed sources), and operates several radiation generating devices. However, emission monitoring is not required for these materials and devices.

Typically, radiological emission data that would be obtained from radionuclide effluent monitoring is used to evaluate the potential effect that a particular site's operations may have on local populations and the environment. Because there are no radionuclide emission sources and no monitoring data for site operations, calculations for maximum individual dose or collective population dose are not possible. As an alternative to these calculations, SNL/CA compares gamma radiation data collected at the site perimeter to offsite data. Results of this comparison are presented in Section 5.4.

SNL/CA is not required to monitor biota or vegetation. The Department of Energy (DOE) RAD-BCG Calculator, a computer tool developed by DOE, is used each year to determine the need and level of monitoring required. The results from applying the tool in 2004 are presented in Section 5.4.

\subsection{Storm Water}

All storm water runoff from SNL/CA is conveyed to the Arroyo Seco, which discharges into Alameda Creek and eventually to the San Francisco Bay. Storm water that flows off buildings, material-handling areas, parking lots, and other impervious surfaces, may pick up pollutants, such as oil and grease, soil, litter, pesticides, and fertilizers. During heavy or continuing storms, runoff may transport pollutants to Arroyo Seco before the storm water has time to evaporate or infiltrate into the ground.

To assess the impact of site operations to storm water discharges, SNL/CA collects samples of surface runoff at nine ${ }^{5}$ locations around the site. These locations, identified on Figure 5-1, were selected because they provide the best representation of drainage areas and activities onsite. Each of the nine locations is sampled twice each wet season, once each during two

\footnotetext{
${ }^{5}$ Nine of the ten sampling locations shown on Figure 5-1 are sampled for the storm water program. Station $\mathrm{N}$ is used to monitor erosion from the Navy Landfill.
} 


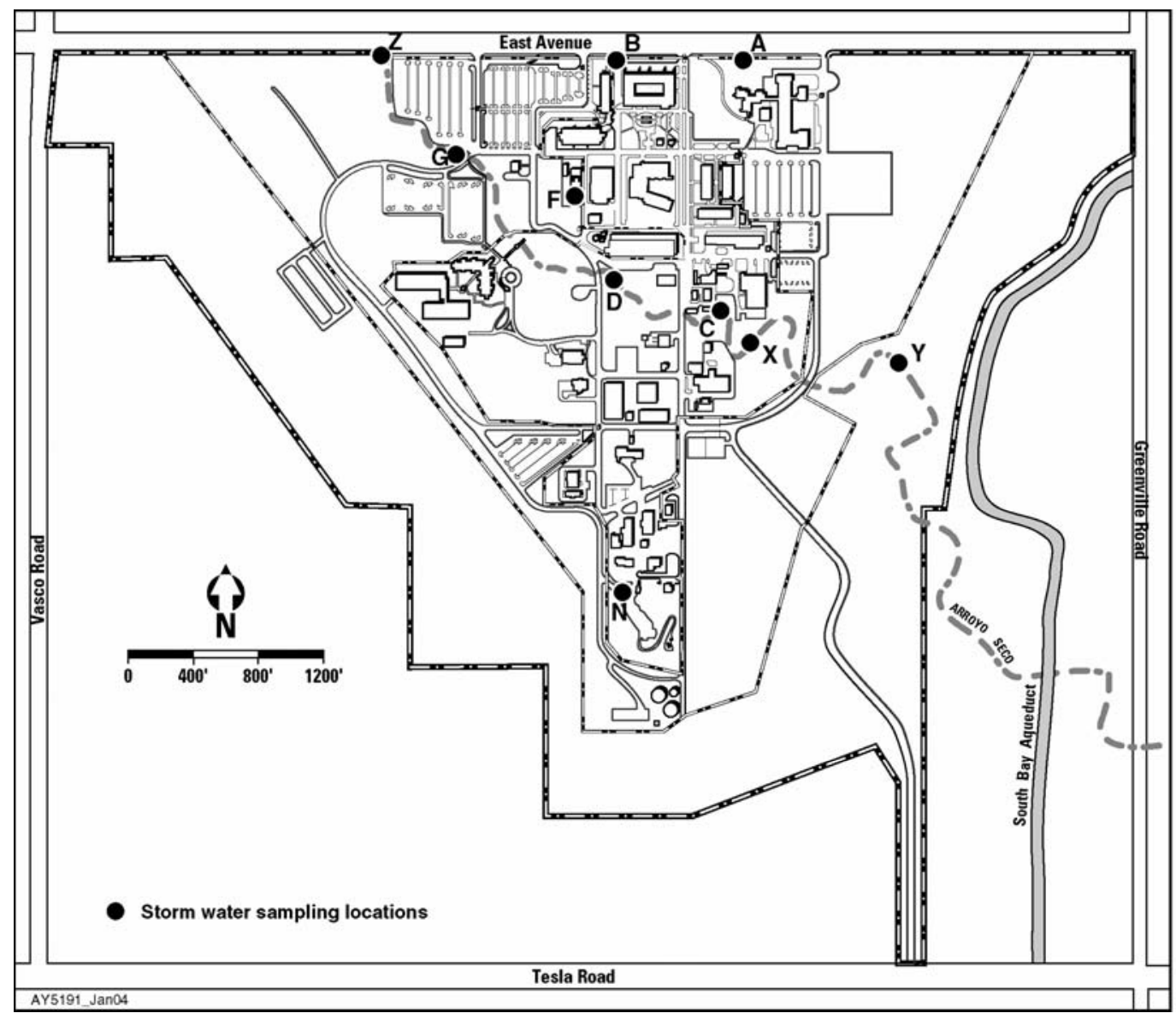

Figure 5-1 Storm Water Sampling Locations

separate storm events, provided there is sufficient runoff. The wet season is from October 1 through May 31. Because any one storm may not produce enough runoff to allow for sample collection at all nine locations, sampling during more than two storm events is generally required. During the 2003/2004 wet season, insufficient runoff occurred at Location Y for all storms sampled; consequently, this location was not sampled.

Storm water discharges at SNL/CA are covered under the State of California NPDES General Permit for Storm Water Discharge Associated with Industrial Activities (General Permit) (California Water Resources Control Board 1997). The General Permit does not establish water quality standards for storm water discharges. Consequently, a comparison of analytical results with regulatory standards cannot be made. Instead the analytical data obtained from monitoring storm water discharge is used to optimize storm water pollution prevention activities at SNL/CA.

\begin{tabular}{|ll|}
\hline & Analytical Parameters - Stormwater \\
$>$ & Specific conductivity \\
$>$ & $\mathrm{pH}$ \\
$>$ & Total suspended solids \\
$>$ & Oil and grease \\
$>$ & Cyanide \\
$>$ & Metals \\
$>$ & Chemical oxygen demand \\
$>$ & Nitrite + nitrate \\
$>$ & Ammonia \\
$>$ & Tritium \\
\hline
\end{tabular}


Analytical results of storm water sampling for the 2003/2004 wet season (October 2003 through May 2004) are presented in Table 5-1. No pollutants were detected in storm water runoff at levels that are a cause for concern. The concentrations of constituents detected in storm water are similar to those detected historically.

Table 5-1 Summary of Analytical Results for Storm Water, 2003/2004 Wet Season

\begin{tabular}{|c|c|c|c|c|c|}
\hline Parameter & $\begin{array}{l}\text { Number of } \\
\text { Samples } \\
\text { Analyzed }\end{array}$ & $\begin{array}{l}\text { Number Found } \\
\text { Below Detection } \\
\text { Limit }\end{array}$ & Detection Limit & $\begin{array}{l}\text { Minimum } \\
\text { Concentration }\end{array}$ & $\begin{array}{l}\text { Maximum } \\
\text { Concentration }\end{array}$ \\
\hline Total suspended solids & 9 & 0 & $3 \mathrm{mg} / \mathrm{L}$ & $5 \mathrm{mg} / \mathrm{L}$ & $86 \mathrm{mg} / \mathrm{L}$ \\
\hline Specific conductivity & 9 & 0 & $1 \mu \mathrm{mho} / \mathrm{cm}$ & $14 \mu \mathrm{mho} / \mathrm{cm}$ & $93 \mu \mathrm{mho} / \mathrm{cm}$ \\
\hline $\mathrm{pH}$ & 9 & 0 & None & 6.0 & 7.1 \\
\hline Oil and grease & 9 & 9 & $1 \mathrm{mg} / \mathrm{L}$ & $<1.0 \mathrm{mg} / \mathrm{L}$ & $<1.0 \mathrm{mg} / \mathrm{L}$ \\
\hline $\begin{array}{l}\text { Chemical oxygen } \\
\text { demand }\end{array}$ & 9 & 1 & $5 \mathrm{mg} / \mathrm{L}$ & $<5.0 \mathrm{mg} / \mathrm{L}$ & $40 \mathrm{mg} / \mathrm{L}$ \\
\hline Cyanide & 9 & 9 & $0.01 \mathrm{mg} / \mathrm{L}$ & $<0.01 \mathrm{mg} / \mathrm{L}$ & $<0.01 \mathrm{mg} / \mathrm{L}$ \\
\hline Tritium & 9 & 9 & $1.59 \mathrm{pCi} / \mathrm{L}$ & $<1.59 \mathrm{pCi} / \mathrm{L}$ & $<1.59 \mathrm{pCi} / \mathrm{L}$ \\
\hline Aluminum & 9 & 0 & $0.05 \mathrm{mg} / \mathrm{L}$ & $0.4 \mathrm{mg} / \mathrm{L}$ & $5.2 \mathrm{mg} / \mathrm{L}$ \\
\hline Arsenic & 9 & 9 & $0.005 \mathrm{mg} / \mathrm{L}$ & $<0.005 \mathrm{mg} / \mathrm{L}$ & $<0.005 \mathrm{mg} / \mathrm{L}$ \\
\hline Cadmium & 9 & 9 & $0.002 \mathrm{mg} / \mathrm{L}$ & $<0.002 \mathrm{mg} / \mathrm{L}$ & $<0.002 \mathrm{mg} / \mathrm{L}$ \\
\hline Iron & 9 & 0 & $0.12 \mathrm{mg} / \mathrm{L}$ & $0.41 \mathrm{mg} / \mathrm{L}$ & $5.3 \mathrm{mg} / \mathrm{L}$ \\
\hline Lead & 9 & 8 & $0.005 \mathrm{mg} / \mathrm{L}$ & $<0.005 \mathrm{mg} / \mathrm{L}$ & $0.005 \mathrm{mg} / \mathrm{L}$ \\
\hline Magnesium & 9 & 0 & $0.10 \mathrm{mg} / \mathrm{L}$ & $0.4 \mathrm{mg} / \mathrm{L}$ & $5.8 \mathrm{mg} / \mathrm{L}$ \\
\hline Mercury & 9 & 9 & $0.0002 \mathrm{mg} / \mathrm{L}$ & $<0.0002 \mathrm{mg} / \mathrm{L}$ & $<0.0002 \mathrm{mg} / \mathrm{L}$ \\
\hline Selenium & 9 & 9 & $0.002 \mathrm{mg} / \mathrm{L}$ & $<0.002 \mathrm{mg} / \mathrm{L}$ & $<0.002 \mathrm{mg} / \mathrm{L}$ \\
\hline Silver & 9 & 9 & $<0.01 \mathrm{mg} / \mathrm{L}$ & $<0.01 \mathrm{mg} / \mathrm{L}$ & $<0.01 \mathrm{mg} / \mathrm{L}$ \\
\hline Zinc & 9 & 0 & $0.02 \mathrm{mg} / \mathrm{L}$ & $0.03 \mathrm{mg} / \mathrm{L}$ & $0.1 \mathrm{mg} / \mathrm{L}$ \\
\hline Ammonia-N & 9 & 9 & $0.5 \mathrm{mg} / \mathrm{L}$ & $<0.5 \mathrm{mg} / \mathrm{L}$ & $<0.5 \mathrm{mg} / \mathrm{L}$ \\
\hline Nitrite + nitrate & 9 & 5 & $0.05 \mathrm{mg} / \mathrm{L}$ & $<1.0+0.05 \mathrm{mg} / \mathrm{L}$ & $13 \mathrm{mg} / \mathrm{L}$ \\
\hline
\end{tabular}

Annually, SNL/CA evaluates storm water pollution prevention practices at each drainage location as part of its monitoring activities. No discharges of unauthorized storm water were found during the annual site inspection. In instances where secondary containment and spill kits were needed, program personnel were made aware of these deficiencies.

During years of sufficient runoff, SNL/CA compares the analytical results from storm water entering the site to storm water exiting the site. In 2004, there was insufficient runoff at the inlet location, Sampling Station Y, to collect samples for analyses. Consequently, a comparison could not be made.

\subsection{Wastewater}

Wastewater effluent generated at SNL/CA consists of sanitary and laboratory discharges. Sanitary effluent is discharged directly to the sewer system. Sewer discharges exit the site through a sewer outfall located at the northern boundary, and join with the LLNL sewer system. Laboratory discharges are generated from general research activities, and from 
operations that qualify as categorical processes subject to Federal pretreatment standards. Laboratory effluent from most laboratory areas is diverted to liquid effluent control system (LECS) holding tanks prior to discharge to the sanitary sewer. SNL/CA monitors wastewater at the sewer outfall, LECS tanks, and at categorical process point sources.

\subsubsection{Sewer Outfall}

SNL/CA operates a sewer outfall and monitoring station at the northern site boundary to continuously monitor wastewater for flow and $\mathrm{pH}$. Samples are also collected at the outfall to monitor compliance with wastewater discharge limits established in the site's Wastewater Discharge Permit. The outfall sampling schedule and analytical parameters are presented in Table 5-2. Consistent with permit requirements, SNL/CA does not analyze wastewater samples collected at the sewer outfall for radioactive constituents.

Table 5-2 Sewer Outfall Sampling Schedule, 2004

\begin{tabular}{lll}
\hline Frequency & Sample Type & Analytical Parameter \\
\hline Daily & Composite & $\begin{array}{l}\text { Archive sample; analyzed only } \\
\text { when weekly composite sample } \\
\text { shows concentration greater than or } \\
\text { equal to 50\% of discharge limit for } \\
\text { metals. }\end{array}$ \\
\hline Weekly & Composite & Metals \\
\hline Monthly & Composite & $\begin{array}{l}\text { Total dissolved solids } \\
\text { Total suspended solids } \\
\end{array}$ \\
& & $\begin{array}{l}\text { Biochemical oxygen demand } \\
\text { Chemical oxygen demand }\end{array}$ \\
\hline Monthly & Grab & $\begin{array}{l}\text { Cyanide } \\
\text { EPA priority organic pollutants }\end{array}$ \\
\hline
\end{tabular}

A summary of analytical results for physical parameters and metals from the SNL/CA sanitary sewer outfall is presented in Table 5-3. In 2004, all liquid effluent from the outfall complied with the site outfall discharge limits for regulated physical parameters and most metals. The site exceeded the discharge limit for copper one time in 2004. The exceedance was found in a daily sample collected on July 24, 2004. Weekly monitoring results for 2004 are consistent with results obtained over the past thirteen years. Figures 5-2 and 5-3 show the trend in weekly monitoring results over this thirteen-year period. Because the data represent weekly composite analyses, Figures 5-2 and 5-3 do not include daily exceedances. As shown, the site has experienced a gradual upward trend in levels of both copper and zinc at the sewer outfall. However, when viewing data from the last five years, 2000 through 2004, both copper and zinc show a downward trend (Figures 5-4 and 5-5). This indicates that SNL/CA's recent efforts to control metals in the sanitary sewer are improving the quality of the effluent. 
Table 5-3 Weekly Composite Sewer Outfall Monitoring Results - Physical Parameters and Metals, 2004

\begin{tabular}{|c|c|c|c|c|c|c|}
\hline Parameter & $\begin{array}{l}\text { Number of } \\
\text { Samples } \\
\text { Analyzed }\end{array}$ & $\begin{array}{l}\text { Quantity } \\
\text { Found Below } \\
\text { Detection } \\
\text { Limit } \\
\end{array}$ & $\begin{array}{l}\text { Detection } \\
\text { Limit }\end{array}$ & $\begin{array}{l}\text { Sewer } \\
\text { Discharge } \\
\text { Limit }\end{array}$ & $\begin{array}{l}\text { Minimum } \\
\text { Concentration }\end{array}$ & $\begin{array}{l}\text { Maximum } \\
\text { Concentration }\end{array}$ \\
\hline $\begin{array}{l}\text { Total suspended } \\
\text { solids }\end{array}$ & 12 & 0 & $5 \mathrm{mg} / \mathrm{L}$ & None & $110 \mathrm{mg} / \mathrm{L}$ & 7700 mg/L \\
\hline $\begin{array}{l}\text { Total dissolved } \\
\text { solids }\end{array}$ & 12 & 0 & $5 \mathrm{mg} / \mathrm{L}$ & None & 73 mg/L & 1200 mg/L \\
\hline $\begin{array}{l}\text { Biochemical } \\
\text { oxygen demand }\end{array}$ & 12 & 0 & $5 \mathrm{mg} / \mathrm{L}$ & None & $31 \mathrm{mg} / \mathrm{L}$ & $1200 \mathrm{mg} / \mathrm{L}$ \\
\hline $\begin{array}{l}\text { Chemical oxygen } \\
\text { demand }\end{array}$ & 12 & 0 & $5 \mathrm{mg} / \mathrm{L}$ & None & $69 \mathrm{mg} / \mathrm{L}$ & $2000 \mathrm{mg} / \mathrm{L}$ \\
\hline Cyanide & 12 & 11 & $0.01 \mathrm{mg} / \mathrm{L}$ & $0.04 \mathrm{mg} / \mathrm{L}$ & $<0.01 \mathrm{mg} / \mathrm{L}$ & $0.01 \mathrm{mg} / \mathrm{L}$ \\
\hline Arsenic & 52 & 49 & $0.005 \mathrm{mg} / \mathrm{L}$ & $0.06 \mathrm{mg} / \mathrm{L}$ & $<0.005 \mathrm{mg} / \mathrm{L}$ & $0.009 \mathrm{mg} / \mathrm{L}$ \\
\hline Cadmium & 52 & 52 & $0.005 \mathrm{mg} / \mathrm{L}$ & $0.14 \mathrm{mg} / \mathrm{L}$ & $<0.005 \mathrm{mg} / \mathrm{L}$ & $<0.005 \mathrm{mg} / \mathrm{L}$ \\
\hline Chromium & 52 & 47 & $0.01 \mathrm{mg} / \mathrm{L}$ & $0.62 \mathrm{mg} / \mathrm{L}$ & $<0.01 \mathrm{mg} / \mathrm{L}$ & $0.02 \mathrm{mg} / \mathrm{L}$ \\
\hline Copper $^{\mathrm{a}}$ & 52 & 0 & $0.01 \mathrm{mg} / \mathrm{L}$ & $1 \mathrm{mg} / \mathrm{L}$ & $0.03 \mathrm{mg} / \mathrm{L}$ & $0.36 \mathrm{mg} / \mathrm{L}$ \\
\hline Lead & 52 & 52 & $0.05 \mathrm{mg} / \mathrm{L}$ & $0.2 \mathrm{mg} / \mathrm{L}$ & $<0.05 \mathrm{mg} / \mathrm{L}$ & $<0.05 \mathrm{mg} / \mathrm{L}$ \\
\hline Mercury & 52 & 46 & $0.0005 \mathrm{mg} / \mathrm{L}$ & $0.01 \mathrm{mg} / \mathrm{L}$ & $<0.0005 \mathrm{mg} / \mathrm{L}$ & $0.0007 \mathrm{mg} / \mathrm{L}$ \\
\hline Nickel & 52 & 52 & $0.02 \mathrm{mg} / \mathrm{L}$ & $0.61 \mathrm{mg} / \mathrm{L}$ & $<0.02 \mathrm{mg} / \mathrm{L}$ & $<0.02 \mathrm{mg} / \mathrm{L}$ \\
\hline Silver & 52 & 50 & $0.01 \mathrm{mg} / \mathrm{L}$ & $0.2 \mathrm{mg} / \mathrm{L}$ & $<0.01 \mathrm{mg} / \mathrm{L}$ & $0.04 \mathrm{mg} / \mathrm{L}$ \\
\hline Zinc & 52 & 0 & $0.02 \mathrm{mg} / \mathrm{L}$ & $3 \mathrm{mg} / \mathrm{L}$ & $0.08 \mathrm{mg} / \mathrm{L}$ & $0.79 \mathrm{mg} / \mathrm{L}$ \\
\hline
\end{tabular}

Copper has been the pollutant of most concern at SNL/CA over the past few years. The last five exceedances of sanitary sewer discharge limits were copper exceedances. As noted in sections 3.10 and 3.13, SNL/CA identified one source of copper contributing to the exceedance in 2004. Ongoing efforts will attempt to identify other potential sources of copper in wastewater. Trends will be closely monitored so that controls can be implemented and impacts minimized.

Sewer outfall samples are also analyzed for priority pollutants that are listed by the U.S. Environmental Protection Agency (EPA) as toxic organics. Because the list is lengthy, SNL/CA routinely reports only positively identified organic constituents. In 2004, sewer outfall samples showed concentrations of chloroform $(5.9-19 \mu \mathrm{g} / \mathrm{L})$, acetone ${ }^{6}(29-330$ $\mu \mathrm{g} / \mathrm{L})$, dibromochloromethane $(7.5 \mu \mathrm{g} / \mathrm{L})$, and phenol $(12-22 \mu \mathrm{g} / \mathrm{L})$. All other constituents on the EPA toxic organic list were below minimum detection limits. The toxic organic discharge limit for the site is $1000 \mu \mathrm{g} / \mathrm{L}$. In 2004, SNL/CA did not exceed this discharge limit.

\footnotetext{
${ }^{6}$ Acetone is not on the EPA Priority Pollutant List but is reported to the City of Livermore as a best practice.
} 


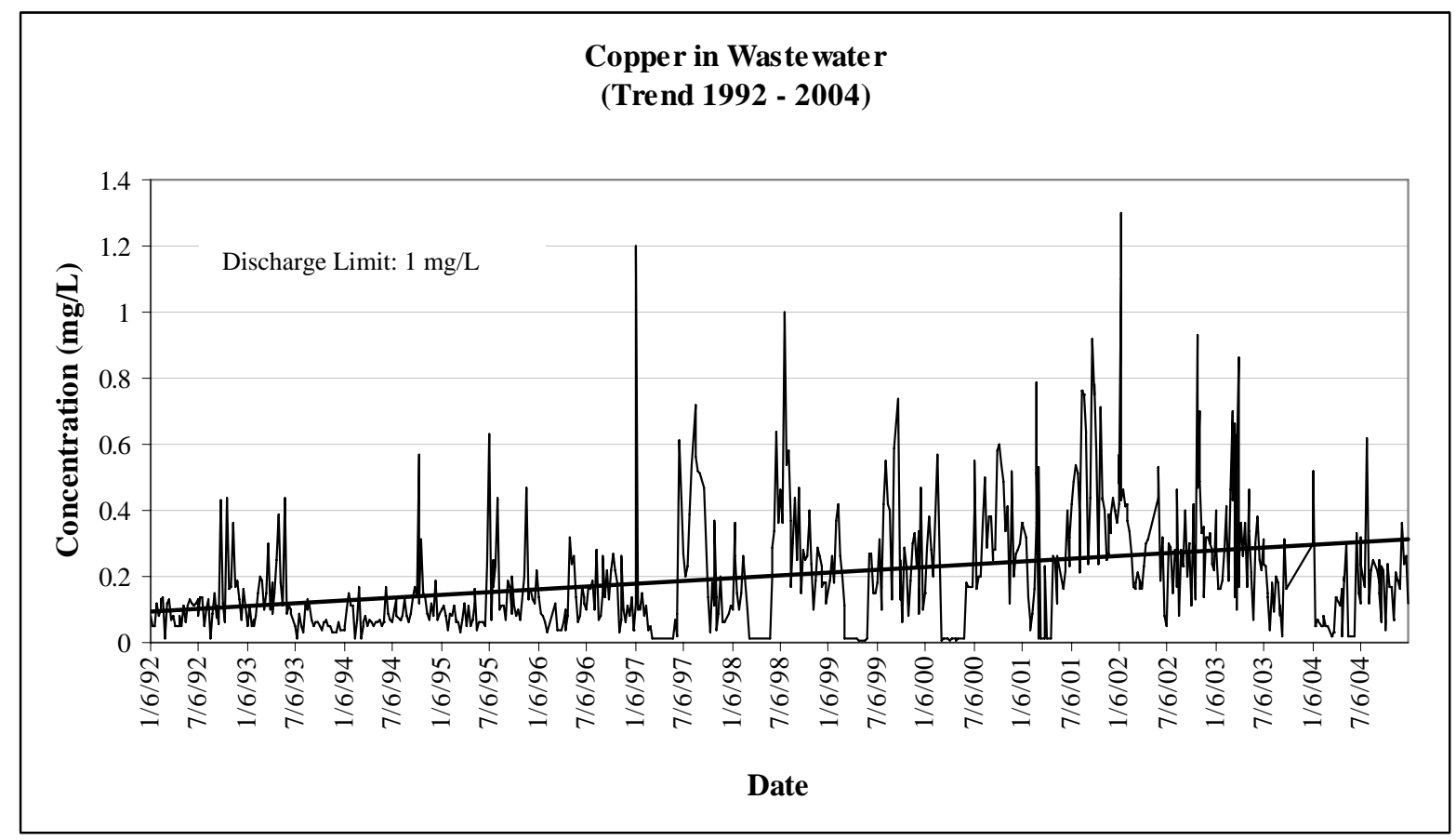

Figure 5-2 Weekly Composite Copper Concentrations in Wastewater, 1992 - 2004

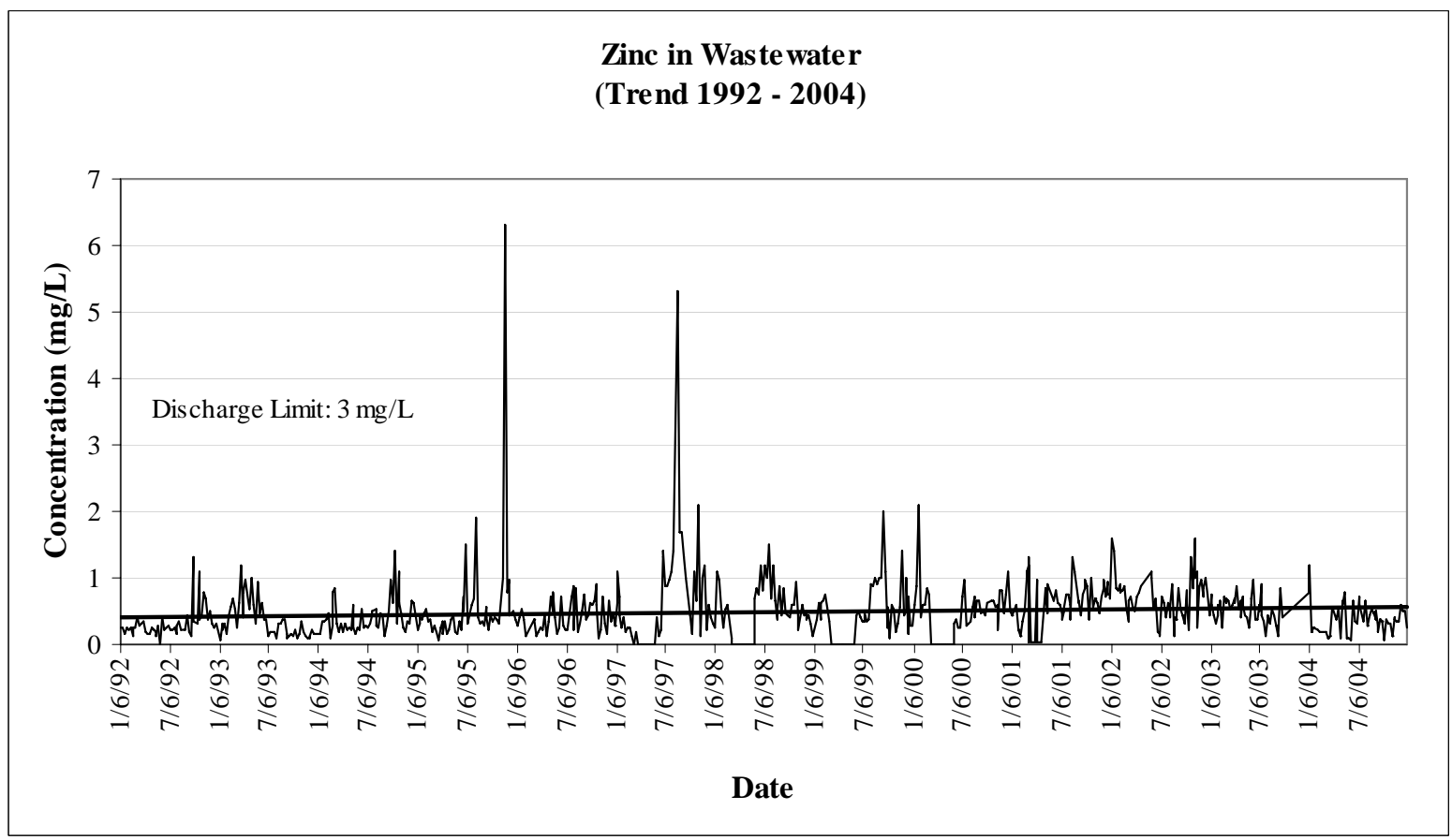

Figure 5-3 Weekly Composite Zinc Concentrations in Wastewater, 1992 - 2004 


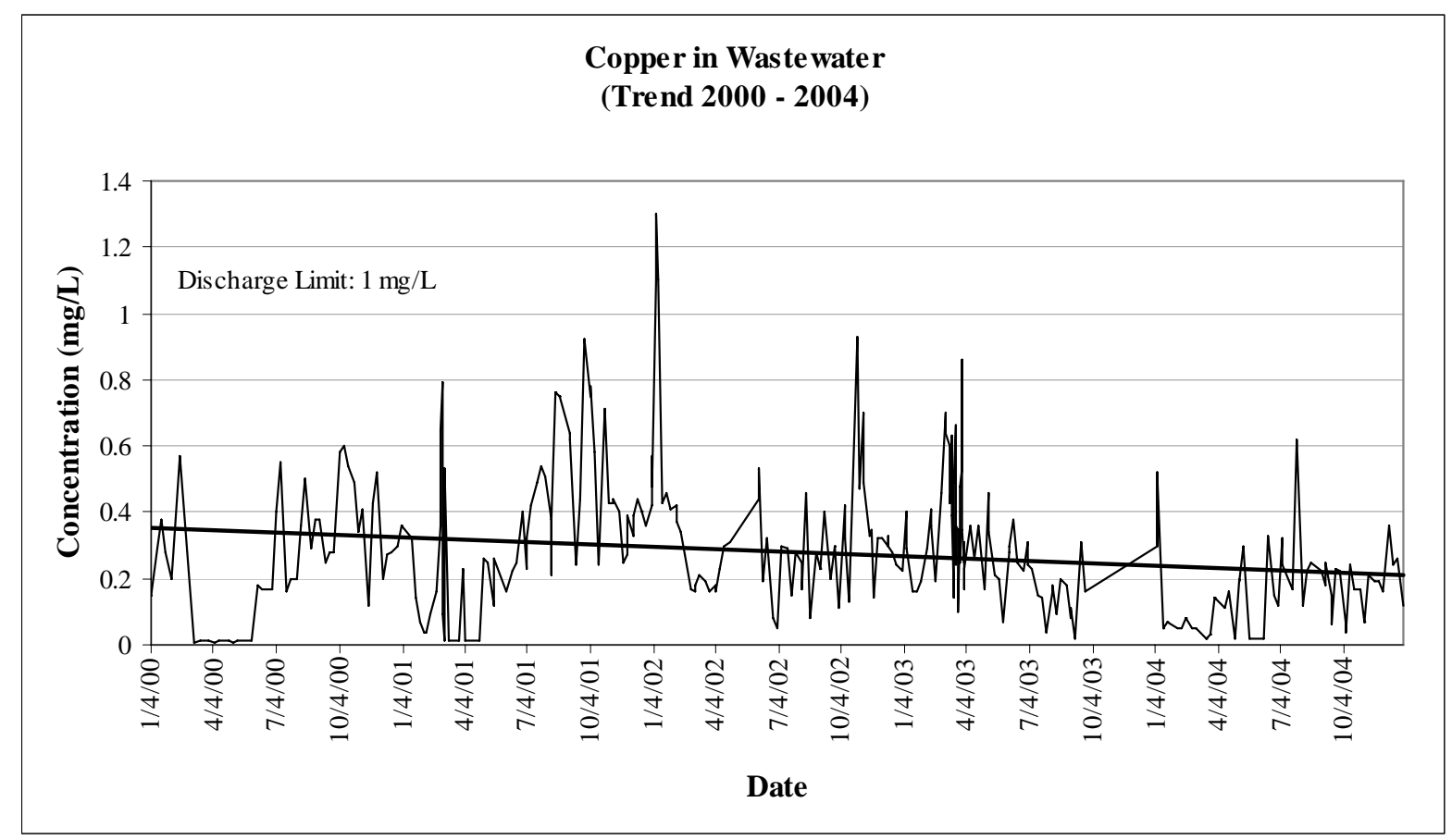

Figure 5-4 Weekly Composite Copper Concentrations in Wastewater, 2000 - 2004

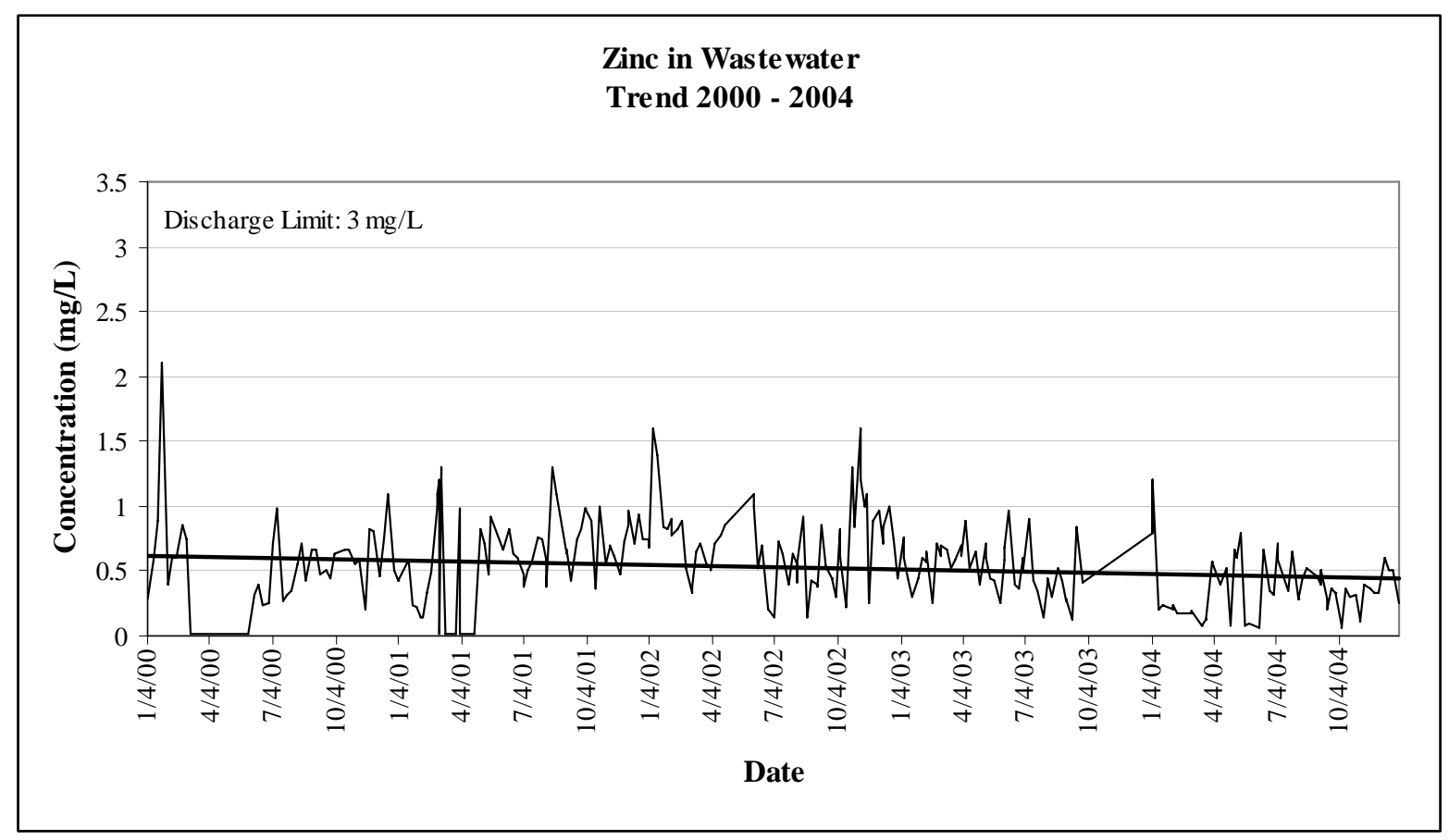

Figure 5-5 Weekly Composite Zinc Concentrations in Wastewater, 2000 - 2004 


\subsubsection{Liquid Effluent Control System}

Effluent from major laboratory facilities is diverted to LECS holding tanks where wastewater can be sampled and analyzed prior to release to the sewer system. SNL/CA operates six LECS. Wastewater from LECS tanks is typically analyzed for metals. Analyses for other parameters associated with the process generating the wastewater may also be done. Five of the LECS tanks are also continuously monitored for $\mathrm{pH}$. One LECS tank is monitored every few years for tritium and uranium; however, in 2004, analyses for radioactive constituents were not warranted.

Wastewater that does not meet the discharge limits at the sewer outfall is transferred to Waste Management for disposal. Depending on the constituents of the wastewater, it may be disposed as hazardous or non-hazardous waste. In 2004, SNL/CA disposed of three tanks of wastewater. Two tanks were disposed of due to elevated levels of silver and zinc. The third tank was disposed of because it was holding wastewater from a drain cleaning effort designed to minimize silver and zinc in the LECS piping.

\subsubsection{Categorical Processes}

Three research operations at SNL/CA are defined as Federal categorical processes subject to the Environmental Protection Agency's pretreatment standards for point sources (40 CFR Part 403, 40 CFR Part 433). These categorical processes include two metal finishing operations and a semiconductor manufacturing operation. ${ }^{7}$ Wastewater from two of these processes is sampled semiannually. One of the metal finishing operations is a closed-loop system that does not discharge effluent to the sanitary sewer, and, therefore, wastewater monitoring is not required.

Samples collected from the metal finishing operation are analyzed for $\mathrm{pH}$, arsenic, metals, and toxic organic pollutants. Table 5-4 presents a summary of semiannual monitoring results for the metal finishing operation. In 2004, two samples contained concentrations of metals (chromium and nickel) above the permit limit. Wastewater batches from which these samples were collected were re-processed to reduce metal concentrations before discharge to the sanitary sewer.

Samples collected from the semiconductor manufacturing operation are analyzed for $\mathrm{pH}$, arsenic, and toxic organic pollutants. Table 5-5 presents a summary of semiannual monitoring results for the semiconductor manufacturing operation. In 2004, all wastewater from this operation met the pretreatment standards.

\footnotetext{
${ }^{7}$ The semiconductor manufacturing operation is a research and development activity exempt from local air pollution regulations. 
Table 5-4 Batch Discharges and Monitoring for Metal Finishing Categorical Process, 2004

\begin{tabular}{|c|c|c|c|c|c|c|}
\hline Parameter & $\begin{array}{l}\text { Number } \\
\text { of } \\
\text { Samples } \\
\text { Analyzed }\end{array}$ & $\begin{array}{l}\text { Number } \\
\text { Found } \\
\text { Below } \\
\text { Detection } \\
\text { Limit }\end{array}$ & $\begin{array}{l}\text { Detection } \\
\text { Limit }\end{array}$ & $\begin{array}{l}\text { Minimum } \\
\text { Concentration }\end{array}$ & $\begin{array}{l}\text { Maximum } \\
\text { Concentration }\end{array}$ & $\begin{array}{l}\text { Permit } \\
\text { Limit }^{\mathrm{a}}\end{array}$ \\
\hline $\mathrm{pH}$ & 15 & -- & None & 6.5 & 7.8 & $5-10^{b}$ \\
\hline Arsenic $^{c}$ & 15 & 1 & $0.005 \mathrm{mg} / \mathrm{L}$ & $<0.005 \mathrm{mg} / \mathrm{L}$ & $0.037 \mathrm{mg} / \mathrm{L}$ & None \\
\hline Cadmium & 15 & 13 & $0.005 \mathrm{mg} / \mathrm{L}$ & $<0.005 \mathrm{mg} / \mathrm{L}$ & $0.017 \mathrm{mg} / \mathrm{L}$ & $0.26 \mathrm{mg} / \mathrm{L}$ \\
\hline Chromium & 15 & 0 & $0.01 \mathrm{mg} / \mathrm{L}$ & $0.04 \mathrm{mg} / \mathrm{L}$ & $2.2 \mathrm{mg} / \mathrm{L}^{\mathrm{d}}$ & $1.71 \mathrm{mg} / \mathrm{L}$ \\
\hline Copper & 15 & 0 & $0.01 \mathrm{mg} / \mathrm{L}$ & $0.05 \mathrm{mg} / \mathrm{L}$ & $0.54 \mathrm{mg} / \mathrm{L}$ & $2.07 \mathrm{mg} / \mathrm{L}$ \\
\hline Lead & 15 & 13 & $0.05 \mathrm{mg} / \mathrm{L}$ & $<0.05 \mathrm{mg} / \mathrm{L}$ & $0.21 \mathrm{mg} / \mathrm{L}$ & $0.43 \mathrm{mg} / \mathrm{L}$ \\
\hline Mercury $^{\mathrm{c}}$ & 15 & 15 & $\begin{array}{l}0.0005 \\
\mathrm{mg} / \mathrm{L}\end{array}$ & $<0.0005 \mathrm{mg} / \mathrm{L}$ & $<0.0005 \mathrm{mg} / \mathrm{L}$ & None \\
\hline Nickel & 15 & 0 & $0.02 \mathrm{mg} / \mathrm{L}$ & $0.03 \mathrm{mg} / \mathrm{L}$ & $3.4 \mathrm{mg} / \mathrm{L}^{\mathrm{d}}$ & $2.38 \mathrm{mg} / \mathrm{L}$ \\
\hline Silver & 15 & 15 & $0.01 \mathrm{mg} / \mathrm{L}$ & $<0.01 \mathrm{mg} / \mathrm{L}$ & $<0.01 \mathrm{mg} / \mathrm{L}$ & $0.24 \mathrm{mg} / \mathrm{L}$ \\
\hline Zinc & 15 & 2 & $0.02 \mathrm{mg} / \mathrm{L}$ & $<0.02 \mathrm{mg} / \mathrm{L}$ & $0.61 \mathrm{mg} / \mathrm{L}$ & $1.48 \mathrm{mg} / \mathrm{L}$ \\
\hline Cyanide & 2 & 2 & $0.02 \mathrm{mg} / \mathrm{L}$ & $<0.01 \mathrm{mg} / \mathrm{L}$ & $<0.01 \mathrm{mg} / \mathrm{L}$ & $0.65 \mathrm{mg} / \mathrm{L}$ \\
\hline $\begin{array}{l}\text { Total toxic } \\
\text { organics }\end{array}$ & 2 & -- & Range $^{e}$ & $0.235 \mathrm{mg} / \mathrm{L}$ & $1.45 \mathrm{mg} / \mathrm{L}$ & $2.13 \mathrm{mg} / \mathrm{L}^{\mathrm{f}}$ \\
\hline \multicolumn{7}{|c|}{ 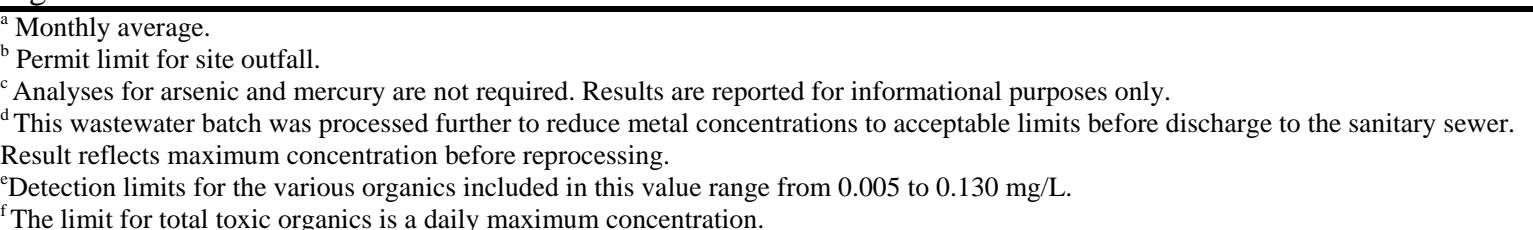 } \\
\hline
\end{tabular}

Table 5-5 Monitoring for Semiconductor Manufacturing Categorical Process, 2004

\begin{tabular}{lllllll}
\hline Parameter & $\begin{array}{l}\text { Number } \\
\text { of } \\
\text { Samples } \\
\text { Analyzed }\end{array}$ & $\begin{array}{l}\text { Number } \\
\text { Found } \\
\text { Below } \\
\text { Detection } \\
\text { Limit }\end{array}$ & $\begin{array}{l}\text { Detection } \\
\text { Limit }\end{array}$ & $\begin{array}{l}\text { Minimum } \\
\text { Concentration }\end{array}$ & $\begin{array}{l}\text { Maximum } \\
\text { Concentration }\end{array}$ & $\begin{array}{l}\text { Permit } \\
\text { Limit } \\
\text { (daily max) }\end{array}$ \\
\hline $\mathrm{pH}$ & 2 & -- & None & 6.7 & 7.0 & $5-10$ \\
\hline Arsenic & 2 & 2 & 0.002 and & $<0.002 \mathrm{mg} / \mathrm{L}$ & $<0.005 \mathrm{mg} / \mathrm{L}$ & $2.09 \mathrm{mg} / \mathrm{L}$ \\
\hline $\begin{array}{l}\text { Total toxic } \\
\text { organics }\end{array}$ & 2 & -- & Range ${ }^{\mathrm{a}} / \mathrm{L}$ & $0.21 \mathrm{mg} / \mathrm{L}$ & $0.24 \mathrm{mg} / \mathrm{L}$ & $1.37 \mathrm{mg} / \mathrm{L}$ \\
\hline${ }^{a}$ Detection limits for the various organics included in this value range from 0.005 to $0.130 \mathrm{mg} / \mathrm{L}$ & & \\
\end{tabular}

\subsection{Groundwater}

SNL/CA has eight groundwater monitoring wells. Sandia monitors groundwater at three former restoration areas and along Arroyo Seco. Four groundwater monitoring wells are used to monitor residual contamination at former restoration areas under a 1989 site clean-up 
order issued by the Regional Water Quality Control Board, San Francisco Bay Region (RWQCB). Two of these wells are located at the Fuel Oil Spill site, and one each at the Trudell Auto Repair Shop site and the Navy Landfill. Four monitoring wells are located along Arroyo Seco to monitor the effect of site operations on groundwater quality. Well AS4 is located upgradient of the developed area of the site and provides background data about local groundwater quality. Groundwater monitoring well locations are shown on Figure 5-6. Table 5-6 provides the sampling schedule for each well location.

Table 5-6 Groundwater Sampling Schedule, 2004

\begin{tabular}{lll}
\hline Well location & Sampling frequency & Analytical parameter \\
\hline Fuel Oil Spill site & Semi-annually & $\begin{array}{l}\text { Total petroleum hydrocarbons diesel- } \\
\text { methane (TPHD) (8015); water } \\
\text { elevation }\end{array}$ \\
\hline Trudell Auto Repair Shop site & Annually & $\begin{array}{l}\text { Volatile halogenated organics (EPA } \\
\text { 601); water elevation }\end{array}$ \\
\hline Navy Landfill & Quarterly & $\begin{array}{l}\text { Volatile halogenated organics (EPA } \\
\text { 601); water elevation }\end{array}$ \\
\hline Arroyo Seco & Annually & $\begin{array}{l}\text { Metals, volatile halogenated organics } \\
\text { (EPA 601), total petroleum }\end{array}$ \\
& & $\begin{array}{l}\text { hydrocarbons-diesel (8015), tritium, } \\
\text { water elevation }\end{array}$ \\
\hline Arroyo Seco & & General minerals \\
\hline
\end{tabular}

A summary of groundwater analytical results for the Navy Landfill and Trudell site is presented in Table 5-7. Groundwater analytical results for Arroyo Seco wells are summarized in Table 5-8. Arroyo Seco well AS-3A and all wells at the Fuel Oil Spill site were dry during 2004, consequently no samples were collected. Complete groundwater analytical results are provided in Chapter 9. As a point of reference, analytical results are compared to federal and state maximum contaminant levels (MCLs), which are applicable for drinking water sources. There are no wells at SNL/CA used as a source for drinking water and MCLs are not standards applied to groundwater at the site.

As in past years, SNL/CA continued to detect carbon tetrachloride at the Navy Landfill well (NLF-6) in 2004. Carbon tetrachloride was detected in only one sample during 2004. The concentration was above the state MCL of $0.5 \mu \mathrm{g} / \mathrm{L}$, but below the federal MCL of $5.0 \mu \mathrm{g} / \mathrm{L}$. The result is similar to that detected in past years. The tetrachloroethene (PCE) contamination found at MW-406 is similar to that found in the past. This contamination is from prior operations at LLNL and part of an ongoing LLNL remediation program. 


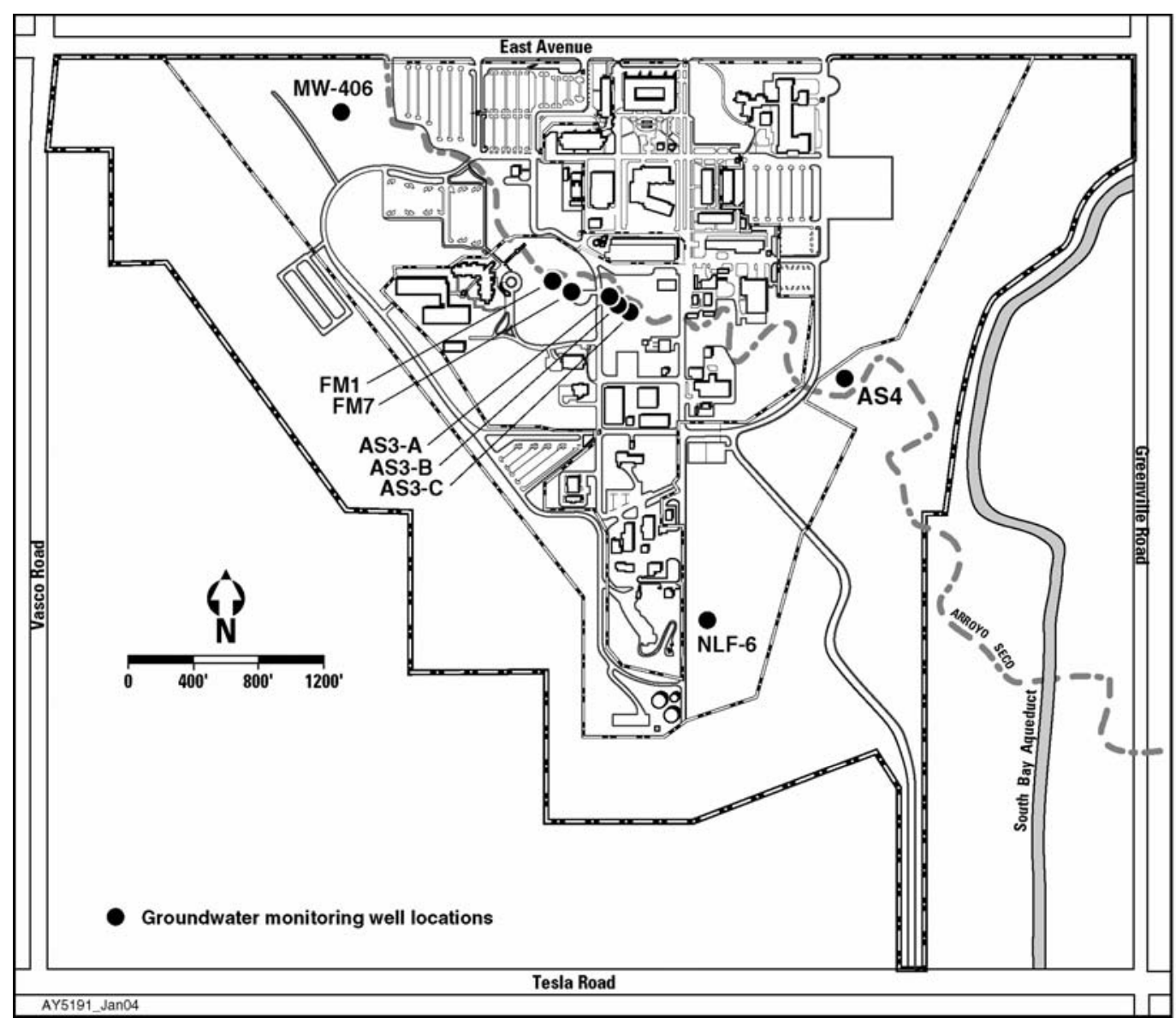

Figure 5-6 Groundwater Monitoring Well Locations

Table 5-7 Summary of Groundwater Analyses at Navy Landfill and Trudell Wells, 2004

\begin{tabular}{|c|c|c|c|c|}
\hline & Date & $\begin{array}{l}\begin{array}{l}\text { Trichloromethane } \\
\text { (chloroform) } \mu \mathrm{g} / \mathrm{L}\end{array} \\
\end{array}$ & $\begin{array}{l}\text { Carbon } \\
\text { Tetrachloride }^{a} \mu \mathrm{g} / \mathrm{L}\end{array}$ & $\begin{array}{l}\text { Tetrachloroethene }{ }^{\mathrm{a}} \\
\text { (PCE) } \mu \mathrm{g} / \mathrm{L}\end{array}$ \\
\hline Detection limit & & 0.5 & 0.5 & 0.5 \\
\hline MCL - California & & & 0.5 & 5 \\
\hline MCL - Federal & & 100 & 5 & 5 \\
\hline \multicolumn{5}{|l|}{ Navy Landfill } \\
\hline NLF-6 & $2 / 24 / 04$ & $<0.5$ & 0.58 & $<0.5$ \\
\hline NLF-6 & $6 / 28 / 04$ & $<0.5$ & $<0.5$ & $<0.5$ \\
\hline NLF-6 & $9 / 15 / 04$ & $<0.5$ & $<0.5$ & $<0.5$ \\
\hline NLF-6 & $12 / 02 / 04$ & $<0.5$ & $<0.5$ & $<0.5$ \\
\hline \multicolumn{5}{|l|}{ Trudell } \\
\hline MW-406 & $5 / 24 / 04$ & $<0.5$ & $<0.5$ & 1.3 \\
\hline
\end{tabular}


Table 5-8 Summary of Groundwater Analyses at Arroyo Seco Wells, 2004

\begin{tabular}{|c|c|c|c|c|c|c|c|c|c|c|}
\hline & & & & & & & $\mathbf{R} \mathbf{~ M e}$ & & & \\
\hline & $\stackrel{\Xi}{\pi}$ & 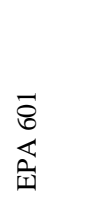 & 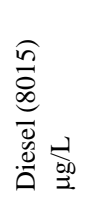 & 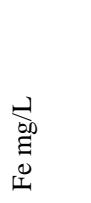 & $\begin{array}{l}\underset{00}{2} \\
\stackrel{E}{<}\end{array}$ & 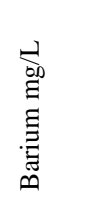 & 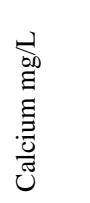 & 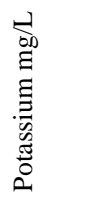 & 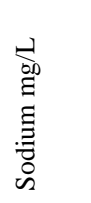 & 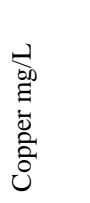 \\
\hline Detection limit & & & 50 & 0.05 & 0.05 & 0.005 & 0.1 & 2 & 1 & 0.005 \\
\hline $\begin{array}{l}\text { MCL - } \\
\text { California }\end{array}$ & & & & & 1 & 1 & & & & \\
\hline $\begin{array}{l}\text { MCL - } \\
\text { Federal } \\
\end{array}$ & & & & & & 2 & & & & \\
\hline AS-3B & $5 / 24 / 04$ & ND & $<50$ & 0.07 & $<0.05$ & 0.14 & 90 & 3.0 & 90 & $<0.005$ \\
\hline AS-3C & $5 / 24 / 04$ & ND & $<50$ & 0.07 & $<0.05$ & 0.1 & 41 & 2.0 & 94 & $<0.005$ \\
\hline AS-4 & $5 / 24 / 04$ & ND & $<50$ & 0.34 & 0.24 & 0.076 & 140 & $<2.0$ & 230 & 0.01 \\
\hline
\end{tabular}

In response to a special request by the RWQCB, SNL/CA developed a Sampling Plan for Emergent Chemicals ${ }^{8}$. This plan describes a one-time only sampling of existing groundwater monitoring wells at the SNL/CA site. Sampling began in the first quarter of 2004 for chromium VI, N-nitrosodimethylamine (NDMA), Perchlorate, 1,4-Dioxane, 1,2,3Trichloropropane, and Polybrominated Diphenyl Ether. Wells AS-3A, FM-1 and FM-7 were dry for all four quarters and could not be sampled. Wells AS-3B, AS-3C, AS-4, MW-11, MW-406, and NLF-6 were sampled the first and second quarters of 2004.

Table 5-9 presents the analytical results for emergent chemicals. The sampling conducted during the first quarter of 2004 showed chromium VI and NDMA at levels of concern to the RWQCB; consequently, a second, confirmation round of sampling was conducted.

Chromium VI was also detected in the second round of samples; however, NDMA was not. NDMA analysis is a non-routine test and seldom requested. As such, not all laboratories are equipped with state-of-the-art instrumentation. For the second round of analyses, a laboratory equipped with the latest instrumentation was contracted to conduct the analysis, yielding more accurate results. Because the NDMA results from the first quarter sampling were suspect, they are not included in Table 5-9.

SNL/CA believes that chromium VI found in groundwater samples is naturally occurring. A review of data for chromium in soils in the Livermore Valley show that chromium minerals are common in this area. The hills to the south of the site were once mined for chromium. The local public water agency has also indicated in a fact sheet that approximately $80 \%$ of the chromium detected in groundwater is in the form of chromium VI.

\footnotetext{
${ }^{8}$ Chemicals of emerging regulatory and environmental concern to the State of California.
} 
Table 5-9 Summary of Groundwater Analyses for Emergent Chemical Sampling, 2004

\begin{tabular}{|c|c|c|c|c|c|c|c|c|}
\hline Well & Date & $\begin{array}{c}\text { Chromium } \\
\text { VI }\end{array}$ & $\begin{array}{c}\text { Chromium } \\
\text { Total }\end{array}$ & Perchlorate & NDMA & $\begin{array}{c}\text { 1,4- } \\
\text { Dioxane }\end{array}$ & $\begin{array}{c}\text { 1,2,2- } \\
\text { Trichloro- } \\
\text { propane }\end{array}$ & $\begin{array}{c}\text { Poly- } \\
\text { brominated } \\
\text { Diphenyl } \\
\text { Ether }\end{array}$ \\
\hline AS-3B & $2 / 23 / 04$ & $6.2 \mu \mathrm{g} / \mathrm{L}$ & $<0.01 \mathrm{mg} / \mathrm{L}$ & $<4 \mu \mathrm{g} / \mathrm{L}$ & suspect & $<2 \mu \mathrm{g} / \mathrm{L}$ & $<0.005 \mu \mathrm{g} / \mathrm{L}$ & $<2 \mu \mathrm{g} / \mathrm{L}$ \\
\hline AS-3B & $5 / 24 / 05$ & $5.7 \mu \mathrm{g} / \mathrm{L}$ & $<0.01 \mathrm{mg} / \mathrm{L}$ & -- & $<2 \mathrm{ng} / \mathrm{L}$ & -- & -- & -- \\
\hline AS-3C & $2 / 23 / 04$ & $3.9 \mu \mathrm{g} / \mathrm{L}$ & $<1 \mathrm{mg} / \mathrm{L}$ & $<4 \mu \mathrm{g} / \mathrm{L}$ & suspect & $<2 \mu \mathrm{g} / \mathrm{L}$ & $<0.005 \mu \mathrm{g} / \mathrm{L}$ & $<2 \mu \mathrm{g} / \mathrm{L}$ \\
\hline AS-3C & $5 / 24 / 04$ & $3.3 \mu \mathrm{g} / \mathrm{L}$ & $<0.01 \mathrm{mg} / \mathrm{L}$ & -- & $<2 \mathrm{ng} / \mathrm{L}$ & -- & -- & -- \\
\hline AS-4 & $2 / 24 / 04$ & $<1 \mu \mathrm{g} / \mathrm{L}$ & $1 \mu \mathrm{g} / \mathrm{L}$ & $<4 \mu \mathrm{g} / \mathrm{L}$ & suspect & $<2 \mu \mathrm{g} / \mathrm{L}$ & $<0.005 \mu \mathrm{g} / \mathrm{L}$ & $<2 \mu \mathrm{g} / \mathrm{L}$ \\
\hline AS-4 & $5 / 24 / 04$ & $<1 \mu \mathrm{g} / \mathrm{L}$ & $<0.01 \mathrm{mg} / \mathrm{L}$ & -- & $<2 \mathrm{ng} / \mathrm{L}$ & -- & -- & -- \\
\hline NLF-6 & $2 / 24 / 04$ & $3.8 \mu \mathrm{g} / \mathrm{L}$ & $33 \mu \mathrm{g} / \mathrm{L}$ & $<4 \mu \mathrm{g} / \mathrm{L}$ & suspect & $<2 \mu \mathrm{g} / \mathrm{L}$ & $<0.005 \mu \mathrm{g} / \mathrm{L}$ & $<2 \mu \mathrm{g} / \mathrm{L}$ \\
\hline NLF-6 & $6 / 28 / 04$ & $3.7 \mu \mathrm{g} / \mathrm{L}$ & $6 \mu \mathrm{g} / \mathrm{L}$ & -- & $<2 \mathrm{ng} / \mathrm{L}$ & -- & -- & -- \\
\hline MW-406 & $2 / 26 / 04$ & $13 \mu \mathrm{g} / \mathrm{L}$ & $16 \mu \mathrm{g} / \mathrm{L}$ & $<4 \mu \mathrm{g} / \mathrm{L}$ & suspect & $<2 \mu \mathrm{g} / \mathrm{L}$ & $<0.005 \mu \mathrm{g} / \mathrm{L}$ & $<2 \mu \mathrm{g} / \mathrm{L}$ \\
\hline MW-406 & $5 / 24 / 04$ & $15 \mu \mathrm{g} / \mathrm{L}$ & $0.01 \mathrm{mg} / \mathrm{L}$ & -- & $<2 \mathrm{ng} / \mathrm{L}$ & -- & -- & -- \\
\hline MW-11 & $2 / 26 / 04$ & $21 \mu \mathrm{g} / \mathrm{L}$ & $28 \mu \mathrm{g} / \mathrm{L}$ & $<4 \mu \mathrm{g} / \mathrm{L}$ & suspect & $<2 \mu \mathrm{g} / \mathrm{L}$ & $<0.005 \mu \mathrm{g} / \mathrm{L}$ & $<2 \mu \mathrm{g} / \mathrm{L}$ \\
\hline MW-11 & $5 / 24 / 04$ & $15 \mu \mathrm{g} / \mathrm{L}$ & $0.03 \mathrm{mg} / \mathrm{L}$ & -- & $<2$ ng/L & -- & -- & -- \\
\hline
\end{tabular}

\subsection{Biological Dose Assessment}

To meet the requirements of DOE Order 450.1 and 5400.5, SNL/CA conducts a biological dose assessment each year using the graded approach presented in DOE Standard 1153-2002 "A Graded Approach for Evaluating Doses to Aquatic and Terrestrial Biota." The technical standard includes models for calculating doses from radionuclide concentration data obtained from sediment and water analyses. In 2004, the RAD-BCG Calculator, a computer tool developed by DOE, was used to calculate doses and determine the need for and level of monitoring required.

The first step in the graded approach is a general screening that compares concentrations of radionuclides in environmental media with derived concentration guides. The ratios of the concentrations to the concentration guides are then summed. If the total equals or exceeds one, then additional analyses are required.

The radionuclides handled in greatest quantity at SNL/CA during past or present operations are tritium and depleted uranium. For 2004, tritium data in storm water runoff at SNL/CA was used in the RAD-BCG Calculator. ${ }^{9}$ The sum of fractions from storm water data totaled $5.9 \times 10^{-6}$. This small fraction indicates that further analysis is not required and that SNL/CA is not required to monitor aquatic or terrestrial biota.

\footnotetext{
${ }^{9}$ In 2002, the first time that the RAD-BCG Calculator was used, sediment data collected by LLNL within Arroyo Seco was also used to calculate doses and determine the need for monitoring. LLNL did not analyze sediments from Arroyo Seco in 2004. SNL/CA is also not required to analyze sediments for radionuclides.
} 


\subsection{Radiation Monitoring}

SNL/CA monitors gamma radiation to ensure that site operations are not contributing significantly to the ambient radiation dose in the surrounding environment. Onsite sources that could contribute to gamma radiation include small, unsealed radioactive isotopes, sealed sources, and several radiation generating devices. SNL/CA maintains four onsite monitoring stations equipped with thermoluminescent dosimeters. Monitoring stations are shown on Figure 5-7. The dosimeters are collected and evaluated quarterly. The data obtained from Sandia monitoring stations is combined with that from LLNL monitoring stations located around the perimeter of the Sandia site to determine the average annual gamma radiation dose at the site perimeter. The combined dose is then compared to the average annual gamma radiation dose at more distant locations in the Livermore Valley, shown on Figure 5-8. If site operations were contributing significantly to the gamma radiation dose, the dosimeters at the site perimeter would show a higher dose than those at more distant locations.

In 2004, the average annual perimeter dose was 60 mrem $(0.60 \mathrm{mSv})$. The average annual dose measurement for distant locations was $57 \mathrm{mrem}(0.57 \mathrm{mSv})$. The 2004 data for both perimeter and distant locations are within the range measured over the last twelve years. Since 1992, the average annual dose at the SNL/CA perimeter ranged from 54.3 mrem to 68 mrem. Over this same period, the average annual dose measured at distant locations ranged from 53.4 mrem to 73 mrem.

Normal fluctuations and natural variations in ambient radiation are most likely the difference between the perimeter and distant location measurements for 2004. SNL/CA does not appear to be a significant contributor to gamma radiation dose in the surrounding environment. 


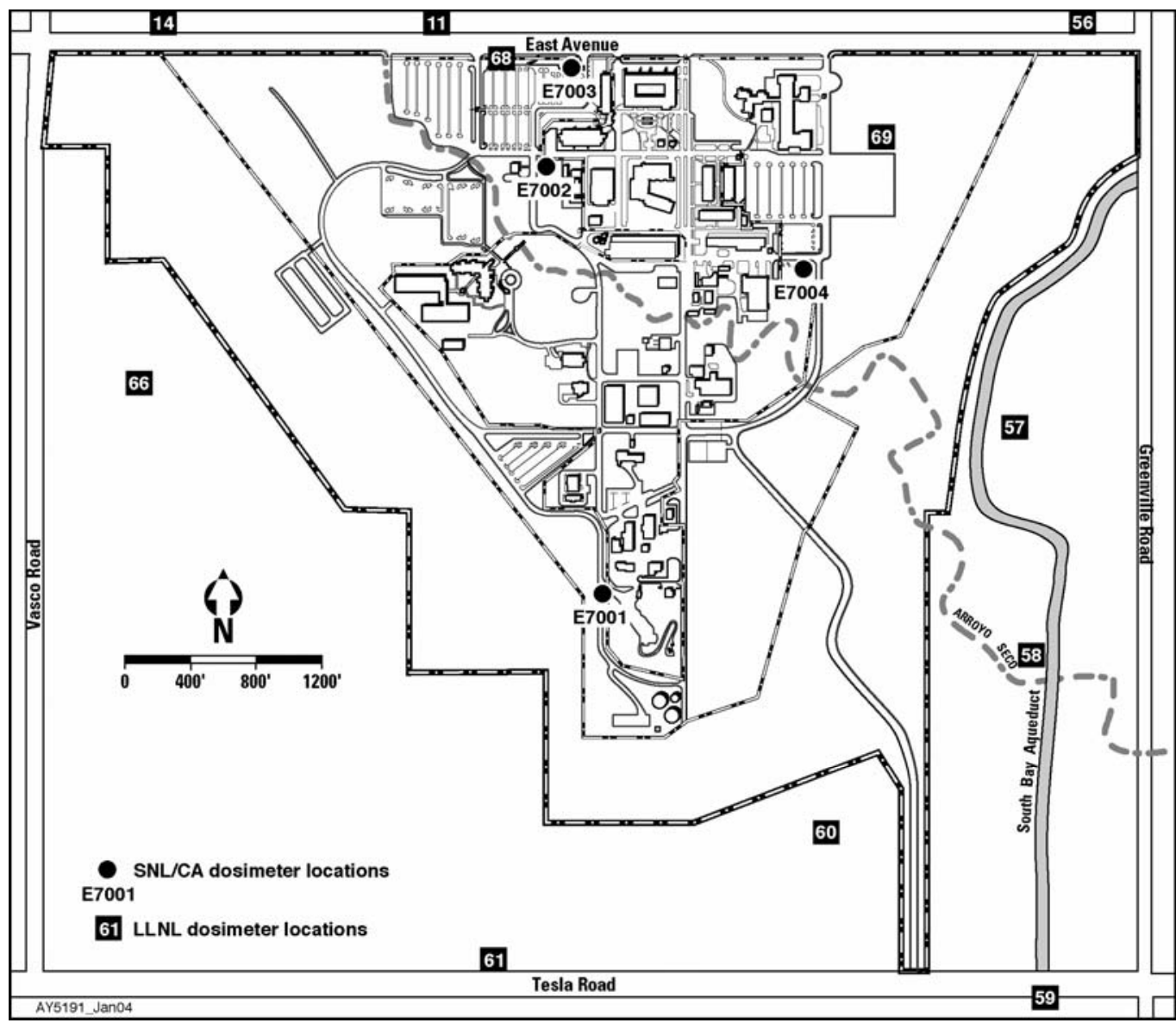

Figure 5-7 Dosimeter Locations at SNL/CA and Around Site Perimeter 


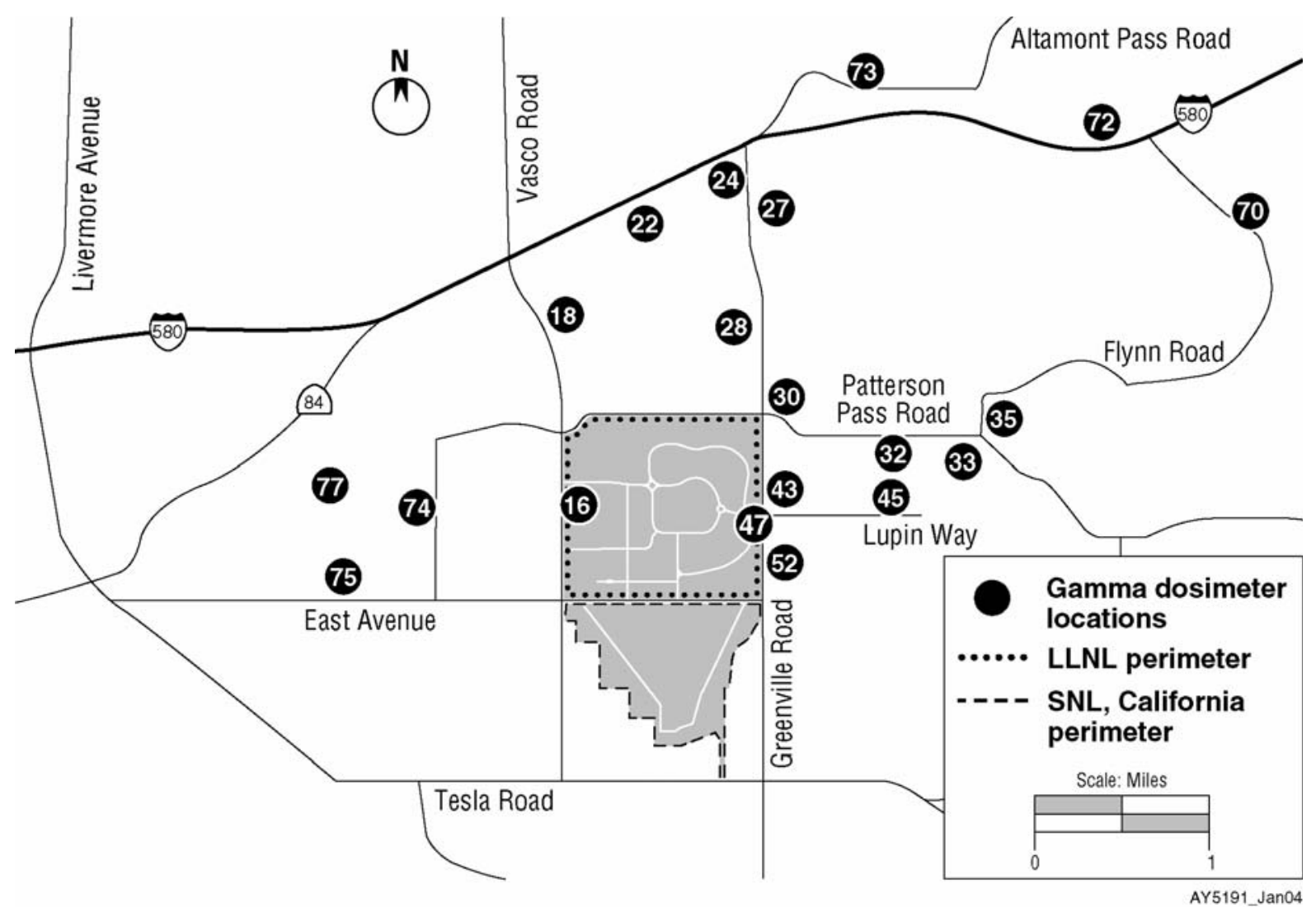

Figure 5-8 Dosimeter Locations in Livermore Valley 


\section{Quality Assurance}

The Sandia Corporate Quality Assurance Program, defined in CPR001.3.2 (SNL 2003) is implemented in California through the Sandia National Laboratories, California (SNL/CA) Quality Program (SNL/CA 2003b) and the Quality Assurance Program Plan (QAPP) (SNL/CA 2003a). Compliance with the Quality Program and QAPP satisfy the requirements established in the Department of Energy (DOE) Nuclear Safety Management Regulations, Subpart A, Quality Assurance Requirements (10 CFR 830), and DOE Order 414.1B, Quality Assurance (DOE 2004a). Quality assurance requirements are incorporated into all site operations, including the Environmental Monitoring and Restoration Program.

\subsection{Program Quality Assurance}

The Environmental Monitoring and Restoration Program ensures quality in its activities through implementation of quality assurance plans and procedures. A program-specific QAPP addresses each of the ten criteria listed above, and documents quality

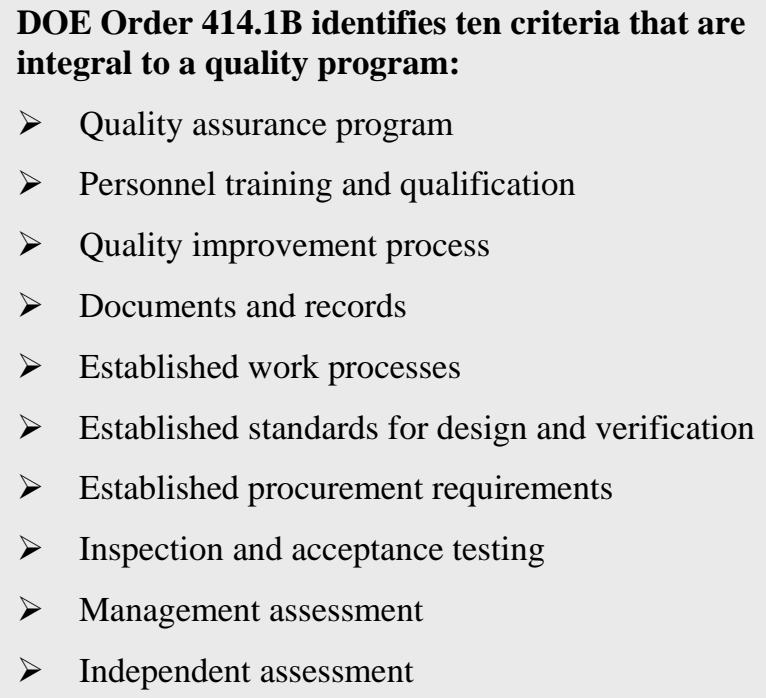

assurance activities performed for the program (SNL 1998). The Environmental Monitoring Plan provides a detailed description of the monitoring and surveillance activities conducted at SNL/CA (SNL 2004). Additional program operating procedures specify training requirements, establish work processes, define data verification and validation processes, and identify reporting and records management requirements. The operating procedures are reviewed by subject matter experts and approved by the Environmental Operations Department Manager.

\subsection{Environmental Sampling}

Protocols for environmental sampling at SNL/CA are contained in activity specific operating procedures. Elements of these protocols include appropriate sampling methods and equipment; sampling frequency; sampling locations; and sample handling, storage, and packaging. Implementation of established protocols ensures that samples are representative of the environmental medium monitored and that monitoring requirements outlined in permits, DOE orders, and regulations are met. Chain-of-custody protocols are also used to ensure quality control through proper transfer of samples from the point of collection to the analytical laboratory. 


\subsection{Sample Analyses}

Analyses of samples collected at SNL/CA are performed using one of three avenues, depending on the sample medium or constituent analyzed. The three avenues are: a State accredited laboratory; the SNL/CA Health Protection Laboratory; or the Sandia National Laboratories, New Mexico (SNL/NM) Health Instrumentation Laboratory.

\subsubsection{Accredited Laboratory}

A State of California accredited laboratory performs analyses of non-radiological samples collected at SNL/CA. To receive accreditation, a laboratory must implement a quality assurance plan. These laboratories are periodically inspected by the California Environmental Protection Agency to ensure that they are operating within regulatory and quality assurance requirements. Consistent with industry standards, non-radiological samples are processed according to Federal Environmental Protection Agency methods.

\subsubsection{SNL/CA Health Physics Laboratory}

Tritium analyses of storm water are performed by the SNL/CA Health Protection Department in an onsite laboratory. These samples are analyzed by liquid scintillation counting, a standard technique for tritium analysis. The Health Physics Laboratory follows the guidance in the Sandia National Laboratories (SNL) Radiation Protection and Laboratory Services Quality Plan (SNL 2002c), and meets the Sandia and DOE quality criteria.

\subsubsection{SNL/NM Health Instrumentation Laboratory}

Thermoluminescent dosimeters used to collect gamma radiation measurements are processed by the Health Instrumentation Department at SNL/NM following established protocols and quality assurance/quality control requirements under the SNL Radiation Protection and Laboratory Services Quality Plan (SNL 2002c). Automated equipment is used to process the samples and analyze the resulting data.

\subsection{Data Verification and Validation}

SNL/CA conducts data verification and validation to ensure that environmental data is precise, accurate, representative, comparable, and complete. Verification and validation are accomplished through analyses of quality control samples and by conducting statistical analyses.

\subsubsection{Quality Control Samples}

Types of quality control samples prepared for the Environmental Monitoring and Restoration Program include duplicate, spiked, and blank samples. A definition of each sample type follows. 
$>$ Duplicate samples are collected at the same time and location, and follow the same method, as a routine sample. These samples are used to assess the precision of sample collection and analytical processes.

> Spiked samples resemble a routine sample, but contain a known amount of one or more of the constituents of interest. These samples are obtained from an independent laboratory that certifies the concentration of the constituents.

> Blank samples resemble a routine sample matrix (e.g. deionized water is used for blank water samples), but lack the constituents of interest. These samples are used to assess background levels of constituents, and possible contamination of the samples in the laboratory or in the field.

SNL/CA's goal for number of quality control samples is $20 \%$ of the total sample load, where feasible. This includes quality control samples initiated at the laboratory. In 2004, SNL/CA collected 13 wastewater quality control samples representing $25 \%$ of the sample load. Five groundwater quality control samples were collected representing 38\% of the sample load. Four storm water quality control samples were collected during the 2003/2004 wet season, representing $27 \%$ of the sample load.

\subsubsection{Statistical Analyses}

Statistical analyses are used to determine completeness, precision, and accuracy of monitoring and surveillance data. Prior to performing statistical analyses, the data is normalized to ensure that valid results are obtained. Descriptions of the statistical tests follow.

Completeness is evaluated by determining the ratio between the number of samples collected and the number of samples scheduled for collection. The data quality objective for completeness is $85 \%$.

Precision is evaluated using three methods: determining the ratio between routine and duplicate samples; tests of significant difference; and calculating the 95\% confidence interval. Data quality objectives vary for precision depending on the results of laboratory analyses.

Accuracy is also evaluated using three methods: determining the ratio between sample results and known values of spiked samples; tests of significant difference; and calculating the 95\% confidence interval. Data quality objectives vary for accuracy depending on the results of laboratory analyses.

Table 6.1 summarizes the results of statistical analyses conducted in 2004. The results show that all precision and accuracy tests passed. The failed completeness tests for storm water and groundwater were due to timing of storm events and falling groundwater levels, respectively, and not to a failure of the sampling program. 
Table 6-1 Summary of Statistical Analyses, 2004

\begin{tabular}{|c|c|c|c|c|c|}
\hline \multirow[t]{2}{*}{ Sample Medium } & \multirow{2}{*}{$\begin{array}{l}\text { Completeness Test } \\
\text { Results } \\
\end{array}$} & \multicolumn{2}{|c|}{ Precision Test } & \multicolumn{2}{|c|}{ Accuracy Test } \\
\hline & & \# of Tests & Results & \# of Tests & Results \\
\hline $\begin{array}{l}\text { Wastewater (sanitary } \\
\text { sewer) }\end{array}$ & $100 \%$ & 6 & All passed & 8 & All passed \\
\hline Storm water & $75 \%{ }^{a}$ & 11 & All passed & -- & -- \\
\hline Groundwater & $63 \%^{\mathrm{b}}$ & 1 & Passed & -- & -- \\
\hline
\end{tabular}




\section{References}

22 California Code of Regulations (CCR), Division 4.5, Environmental Health Standard for Management of Hazardous Waste.

10 Code of Federal Regulations (CFR) Part 830, Department of Energy, Nuclear Safety Management, Subpart A, Quality Assurance Requirements, Federal Register Vol. 66, Number 7, January 10, 2001.

10 CFR Part 1021, Department of Energy, National Environmental Policy Act Implementing Procedures, January 1997.

40 CFR Part 61, National Emissions Standards for Hazardous Air Pollutants, Subpart H National Emissions Standards for Emissions of Radionuclides Other Than Radon From Department of Energy Facilities, December 1989.

40 CFR Part 82, Environmental Protection Agency, Protection of Stratospheric Ozone, July 1, 2004.

40 CFR Part 262.41, Environmental Protection Agency, Standards Applicable to Generators of Hazardous Waste, Subpart D, Record-keeping and Reporting, July 1, 2001.

40 CFR Part 403, Environmental Protection Agency, General Pretreatment Regulations for Existing and New Sources of Pollution.

40 CFR Part 433, Environmental Protection Agency, Metal Finishing Point Source Category.

7 United States Code (USC) §136, Federal Insecticide, Fungicide, and Rodenticide Act, 1972.

15 USC §2601 et. seq., Toxic Substances Control Act of 1976.

16 USC § 470, National Historic Preservation Act of 1966.

16 USC § 703 et. seq., Migratory Bird Treaty Act of 1918.

16 USC §1531 et. seq., Endangered Species Act of 1973.

33 USC §1251, Clean Water Act of 1977.

42 USC § 2011 et. seq., Atomic Energy Act of 1954.

42 USC § 6901 et. seq., Resource Conservation and Recovery Act of 1976.

42 USC § 6961, Federal Facility Compliance Act of 1992. 
42 USC § 7401, Clean Air Act Amendments of 1990.

42 USC § 9601, Comprehensive Environmental Response, Compensation, and Liability Act of 1980.

42 USC §11001 et. seq., Superfund Amendments and Reauthorization Act of 1986, Emergency Planning and Community Right-to-Know Act.

42 USC §13101 et. seq., Pollution Prevention Act of 1990.

Assembly Bill 2185, California Hazardous Materials Release Response Plans and Inventory Law, 1987.

California Health and Safety Code, Division 20, Chapter 6.5, § 25100 et. seq., Hazardous Waste Control Law.

California Health and Safety Code, Division 20, Chapter 6.7, §§ 25280-25299.8, Underground Storage of Hazardous Substances.

California Health and Safety Code, Division 20, Chapter 6.95, § 25500, et. Seq., Hazardous Materials Release Response Plans and Inventory.

California Health and Safety Code, Division 104, Part 14, §§ 117600-118360, Medical Waste Management Act.

California Regional Water Quality Control Board, San Francisco Bay Region (California RWQCB) 1989, Order No. 89-184, Revision of Site Cleanup Order, Sandia Corporation and U.S. Department of Energy, Livermore, December 1989.

California Water Resources Control Board 1997, State of California, NPDES General Permit for Storm Water Discharge Associated with Industrial Activities, April 1997.

California Water Resources Control Board 1999, State of California, NPDES General Permit for Storm Water Discharge Associated with Construction Activity, August 1999.

Department of Energy (DOE) 1986, Comprehensive Environmental Assessment and Response Program, Phase I: Installation Assessment, Sandia National Laboratories, Livermore, September, 1986.

DOE 1993, DOE Order 5400.5, change 2, Radiation Protection of the Public and the Environment, January 7, 1993.

DOE 2001b, DOE Order 435.1, change 1, Radioactive Waste Management, August 28, 2001.

DOE 2002a, Biological Assessment for Continued Operation of Sandia National Laboratories, California, July 15, 2002.

DOE 2003a, Final Site-wide Environmental Assessment of the Sandia National Laboratories/California, DOE/EA-1422, January 2003. 
DOE 2003b, DOE order 450.1, Environmental Protection Program, January 15, 2003.

DOE 2003c, Site Wide Environmental Assessment for SNL/CA, Finding of No Significant Impact, March 20, 2003.

DOE 2003d, DOE Order 231.1A, Environment, Safety, and Health Reporting, August 19, 2003.

DOE 2004a, DOE Order 414.1B, Quality Assurance, April 29, 2004.

DOE 2004b, DOE G 450.1-3, Environmental Guidelines for Development of Cultural Resource Management Plans - Update, September 22, 2004.

DOE 2005, U.S. Department of Energy’s Pollution Prevention (P2) Program, DOE’s Buying Recycled and Environmentally Preferable Products Program, FY 2004 Site Data, http://www.eh.doe.gov/p2/ap/sitedata2004.cfm, January 25, 2005.

Executive Order (EO) 11988, Floodplain Management, Federal Register, Vol. 42, pp. 26951, May 25, 1977.

EO 11990, Protection of Wetlands, Federal Register, Vol. 42, pp. 26961, May 25, 1977.

EO 13101, Greening the Government Through Waste Prevention, Recycling, and Federal Acquisition, September 14, 1998.

EO 13148, Greening of the Government Through Leadership in Environmental Management, April 21, 2000.

Matthews, Graham \& Associates (Matthews) 2002, Management Plan for Arroyo Seco at Sandia National Labs, Livermore, CA, April 2002.

Sandia National Laboratories (SNL) 1997, Environment, Health, and Safety Manual (MN 471001), Section 6S - Toxic Substances Control Act (TSCA), December 3, 1997.

SNL 1998, Quality Assurance Program Plan, SAND 98-8003, June 1998.

SNL 2002b, Historic Building Survey, Sandia National Laboratories/California, October 30, 2002.

SNL 2002c, Quality Plan, Integrated Safety and Security Center, Radiation Protection and Laboratory Services, RPLS-00-02, November 13, 2002.

SNL 2003, Corporate Quality Assurance Program, Corporate Process Requirements No. CPR001.3.2, http://www-irn.sandia.gov/policy/leadership/quality.html, August 1, 2003.

SNL 2004, Environmental Monitoring Plan, SAND 2004-8058, February 2004. 
SNL California (SNL/CA) 2002, Sandia National Laboratories, California Environmental Information Document, SAND 2002-8053, March 2002.

SNL/CA 2003a, Sandia National Laboratories, California Quality Assurance Program Plan, https:wfsprod01.sandia.gov/groups/srnuscitizens/documents/document/wfs070514.pdf, May 12, 2003.

SNL/CA 2003b, Sandia National Laboratories, California Quality Program, http://www.ran.sandia.gov/ctr/ctr2200/dpt2266/quality/plan.html, May 23, 2003.

SNL/CA 2004a, Administrative Procedure for Conducting National Environmental Policy Act Reviews of Proposed Projects at Sandia National Laboratories, California, OP471343, Issue H, January 7, 2004.

SNL/CA 2004b, Operating Procedure 471741, Storm Drain Spill Prevention and Control, Issue C, July 15, 2004.

SNL/CA 2004c, Standard Operating Procedure SP471911, Handling and Storage of Pesticides, May 10, 2004.

SNL/CA 2004d, 2004 Annual Report on Waste Generation and Pollution Prevention Progress as required by DOE Order 450.1, November 24, 2004.

Senate Bill 14, California Hazardous Waste Source Reduction and Management Review Act of 1989.

United States District Court for the District of Columbia (US District Court) 2002, Case Number 01-1291 (RJL), Home Builders Associations of Northern California, et al., Plaintiffs, and El Dorado County, California, Intervenor-Plaintiff, v. Gale A. Norton, Secretary of the Department of Interior, et. al., Defendants, and Jumping Frog Research Institute, et al., Intervenor-Defendants, November 6, 2002.

United States Fish and Wildlife Service (USFWS) 2004a, Proposed Rule, Endangered and Threatened Wildlife and Plants; Proposed Designation of Critical habitat for the California Red-legged Frog (Rana aurora draytonii), Federal Register, April 13, 2004 (Volume 69, Number 71).

USFWS 2004b, Final Rule, Endangered and Threatened Wildlife and Plants; Determination of Threatened Status for the California Tiger Salamander, and Special Rule Exemption for Existing Routine Ranching Activities, Federal Register, August 4, 2004 (Volume 69, Number 149). 


\section{Glossary}

Ambient air

Biochemical

oxygen demand

Categorical process

Chemical oxygen

demand

Dose

Dosimeter

Effluent

Emission

Ephemeral stream

External radiation

Fluvial sediments

Lacustrine

sediments

Mixed waste

$\mathrm{pH}$

Riparian
The surrounding atmosphere, usually the outside air, as it exists around people, plants, and structures. It does not include the air next to emission sources.

A measure of the amount of dissolved oxygen that microorganisms need to break down organic matter in water. Used as an indicator of water quality.

An industrial process that discharges wastewater and is regulated under 40 CFR, Part 403.

The amount of oxygen required to degrade the organic compounds of wastewater. Used to measure the overall level of organic contamination in wastewater.

A term denoting the quantity of radiation energy absorbed.

A portable detection device for measuring the total accumulated exposure to ionizing radiation.

A liquid or gaseous waste discharged to the environment.

A gaseous or liquid stream containing one or more contaminants.

A stream that flows only for a short duration during and following rainfall.

Radiation originating from a source outside the body.

A sedimentary deposit consisting of material transported by, suspended in, or laid down by a river or stream.

Sediments formed in, or relating to, a lake.

Waste that contains both radioactive and hazardous constituents.

A measure of hydrogen ion concentration in an aqueous solution. Acidic solutions have a $\mathrm{pH}$ less than 7 , basic solutions have a $\mathrm{pH}$ greater than 7 , and neutral solutions have a $\mathrm{pH}$ of 7 .

Pertaining to, situated in, or adapted to living on the banks of rivers and streams. 
Specific Measure of the ability of a material to conduct electricity.

conductivity

Strike-slip fault A fault with horizontal movement along the break where slipping is parallel with the strike of the fault.

Thermoluminescent A type of dosimeter. After being exposed to radiation, the material in dosimeter the dosimeter (lithium fluoride) luminesces upon being heated. The amount of light the material emits is proportional to the amount of radiation (dose) to which it was exposed.

Total dissolved Solids in water that pass through a filter. A measure of the amount of solids material dissolved in water.

Total suspended Solids in water that can be trapped in a filter. Solids can include silt, solids decaying plant and animal matter, industrial wastes, and sewage.

Transverse fault A fault that strikes obliquely or perpendicular to the general structural trend of the region. 


\section{Groundwater Analytical Results}


Table 9-1 Results of Quarterly Groundwater Analyses at SNL/CA, 2004

\begin{tabular}{|c|c|c|c|c|c|c|c|c|c|c|c|c|c|c|c|c|c|c|}
\hline & Date & 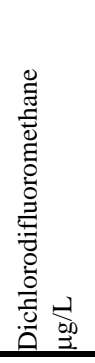 & 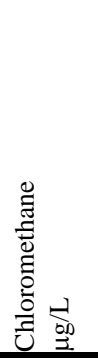 & 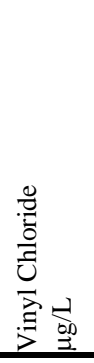 & 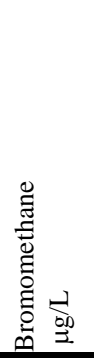 & 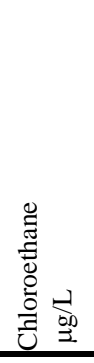 & 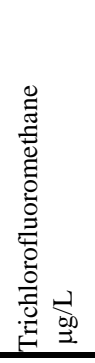 & 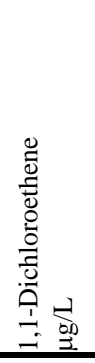 & 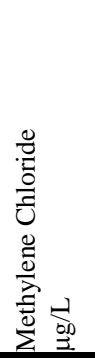 & 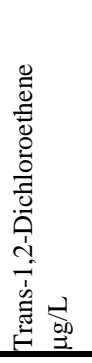 & 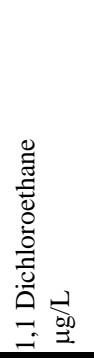 & 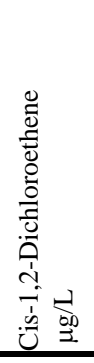 & 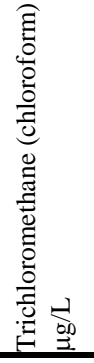 & 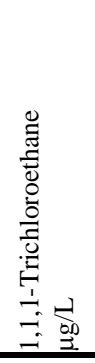 & 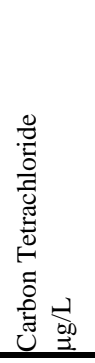 & 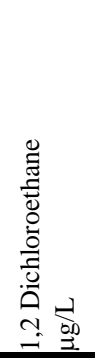 & 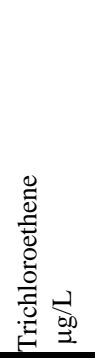 & 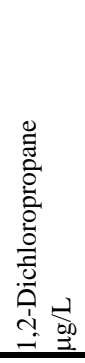 \\
\hline $\begin{array}{l}\text { Detection } \\
\text { limit }\end{array}$ & & 2.0 & 0.5 & 1.0 & 1.0 & 0.5 & 0.5 & 0.5 & 2.0 & 0.5 & 0.5 & 0.5 & 0.5 & 0.5 & 0.5 & 0.5 & 0.5 & 0.5 \\
\hline $\begin{array}{l}\text { MCL - } \\
\text { California } \\
\end{array}$ & & & & 0.5 & & & 150 & 6 & & 10 & 5 & 6 & & 200 & 0.5 & 0.5 & 5 & 5 \\
\hline $\begin{array}{l}\text { MCL - } \\
\text { Federal } \\
\end{array}$ & & & & 2 & & & & 7 & 5 & 100 & & 70 & 100 & 200 & 5 & 5 & 5 & 5 \\
\hline Well ID & & & & & & & & & & & & & & & & & & \\
\hline NLF-6 & $2 / 24 / 04$ & ND & ND & ND & ND & ND & ND & ND & ND & ND & ND & ND & ND & ND & 0.58 & ND & ND & ND \\
\hline & $6 / 28 / 04$ & ND & ND & ND & ND & ND & ND & ND & ND & ND & ND & ND & ND & ND & ND & ND & ND & ND \\
\hline & $6 / 28 / 04(\mathrm{FD})^{\mathrm{a}}$ & ND & ND & ND & ND & ND & ND & ND & ND & ND & ND & ND & ND & ND & ND & ND & ND & ND \\
\hline & $9 / 15 / 04$ & ND & ND & ND & ND & ND & ND & ND & ND & ND & ND & ND & ND & ND & ND & ND & ND & ND \\
\hline & $12 / 02 / 04$ & ND & ND & ND & ND & ND & ND & ND & ND & ND & ND & ND & ND & ND & ND & ND & ND & ND \\
\hline MW-406 & $5 / 24 / 04$ & ND & ND & ND & ND & ND & ND & ND & ND & ND & ND & ND & ND & ND & ND & ND & ND & ND \\
\hline AS-3A ${ }^{b}$ & & -- & -- & -- & -- & -- & -- & -- & -- & -- & -- & -- & -- & -- & -- & -- & -- & -- \\
\hline AS-3B & $5 / 24 / 04$ & ND & ND & ND & ND & ND & ND & ND & ND & ND & ND & ND & ND & ND & ND & ND & ND & ND \\
\hline AS-3C & $5 / 24 / 04$ & ND & ND & ND & ND & ND & ND & ND & ND & ND & ND & ND & ND & ND & ND & ND & ND & ND \\
\hline FM-1 ${ }^{\mathrm{b}}$ & & -- & -- & -- & -- & -- & -- & -- & -- & -- & -- & -- & -- & -- & -- & -- & -- & -- \\
\hline FM-7 ${ }^{b}$ & & -- & -- & -- & -- & -- & -- & -- & -- & -- & -- & -- & -- & -- & -- & -- & -- & -- \\
\hline AS-4 & $5 / 24 / 04$ & -- & -- & -- & -- & -- & -- & -- & -- & -- & -- & -- & -- & -- & -- & -- & -- & -- \\
\hline
\end{tabular}


Table 9-1 Results of Groundwater Analyses at SNL/CA, 2004 (continued)

\begin{tabular}{|c|c|c|c|c|c|c|c|c|c|c|c|c|c|c|c|c|c|c|c|}
\hline & Date & 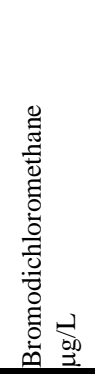 & 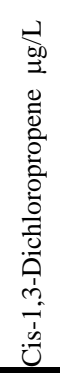 & 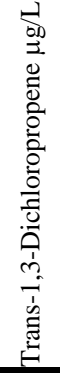 & 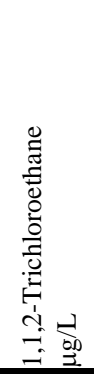 & 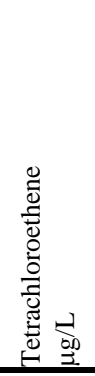 & 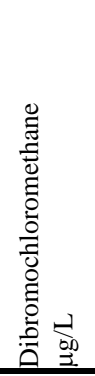 & 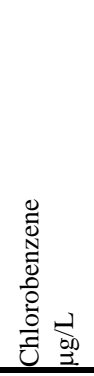 & 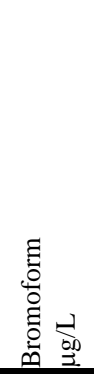 & 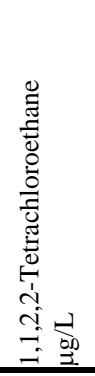 & 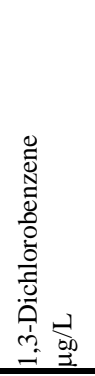 & 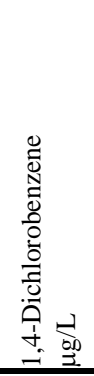 & 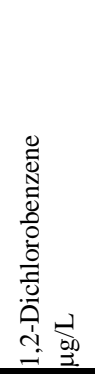 & 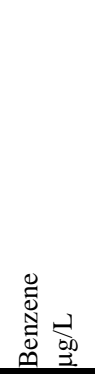 & 节 & 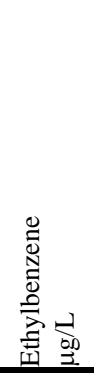 & 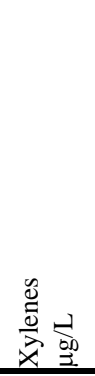 & 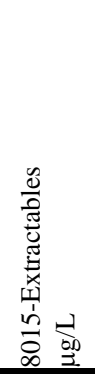 & 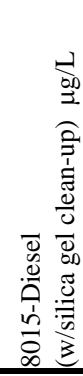 \\
\hline $\begin{array}{l}\text { Detection } \\
\text { limit } \\
\end{array}$ & & 0.5 & 0.5 & 0.5 & 0.5 & 0.5 & 0.5 & 0.5 & 0.5 & 0.5 & 0.5 & 0.5 & 0.5 & 0.5 & 0.5 & 0.5 & 0.5 & 50 & 50 \\
\hline $\begin{array}{l}\text { MCL - } \\
\text { California }\end{array}$ & & & 05 & & 32 & 5 & & 30 & & 1 & & 5 & & 1 & & & 1750 & & \\
\hline $\begin{array}{l}\text { MCL - } \\
\text { Federal }\end{array}$ & & 100 & & & 5 & 5 & 100 & 100 & 100 & & 600 & 75 & 600 & 5 & 1000 & 700 & 10000 & & \\
\hline Well ID & & & & & & & & & & & & & & & & & & & \\
\hline NLF-6 & $2 / 24 / 04$ & ND & ND & ND & ND & ND & ND & ND & ND & ND & ND & ND & ND & -- & -- & -- & -- & -- & -- \\
\hline & $6 / 28 / 04$ & ND & ND & ND & ND & ND & ND & ND & ND & ND & ND & ND & ND & -- & -- & -- & -- & -- & -- \\
\hline & $6 / 28 / 04(\mathrm{FD})^{\mathrm{a}}$ & ND & ND & ND & ND & ND & ND & ND & ND & ND & ND & ND & ND & -- & -- & -- & -- & -- & -- \\
\hline & 9/15/04 & ND & ND & ND & ND & ND & ND & ND & ND & ND & ND & ND & ND & -- & -- & -- & -- & -- & -- \\
\hline & $12 / 02 / 04$ & ND & ND & ND & ND & ND & ND & ND & ND & ND & ND & ND & ND & -- & -- & -- & -- & -- & -- \\
\hline MW-406 & $5 / 24 / 04$ & ND & ND & ND & ND & 1.3 & ND & ND & ND & ND & ND & ND & ND & -- & -- & -- & -- & -- & -- \\
\hline AS-3A ${ }^{b}$ & & -- & -- & -- & -- & -- & -- & -- & -- & -- & -- & -- & -- & -- & -- & -- & -- & -- & -- \\
\hline AS-3B & $5 / 24 / 04$ & ND & ND & ND & ND & ND & ND & ND & ND & ND & ND & ND & ND & -- & -- & -- & -- & -- & ND \\
\hline AS-3C & $5 / 24 / 04$ & ND & ND & ND & ND & ND & ND & ND & ND & ND & ND & ND & ND & -- & -- & -- & -- & -- & ND \\
\hline FM-1 $^{\text {b }}$ & & -- & -- & -- & -- & -- & -- & -- & -- & -- & -- & -- & -- & -- & -- & -- & -- & -- & -- \\
\hline FM-7 $^{\text {b }}$ & & -- & -- & -- & -- & -- & -- & -- & -- & -- & -- & -- & -- & -- & -- & -- & -- & -- & -- \\
\hline AS-4 & $5 / 24 / 04$ & ND & ND & ND & ND & ND & ND & ND & ND & ND & ND & ND & ND & -- & -- & -- & -- & -- & ND \\
\hline
\end{tabular}


Candia National Laboratories, California Site Environmental Report for 2004

Table 9-1 Results of Groundwater Analyses at SNL/CA, 2004 (continued)

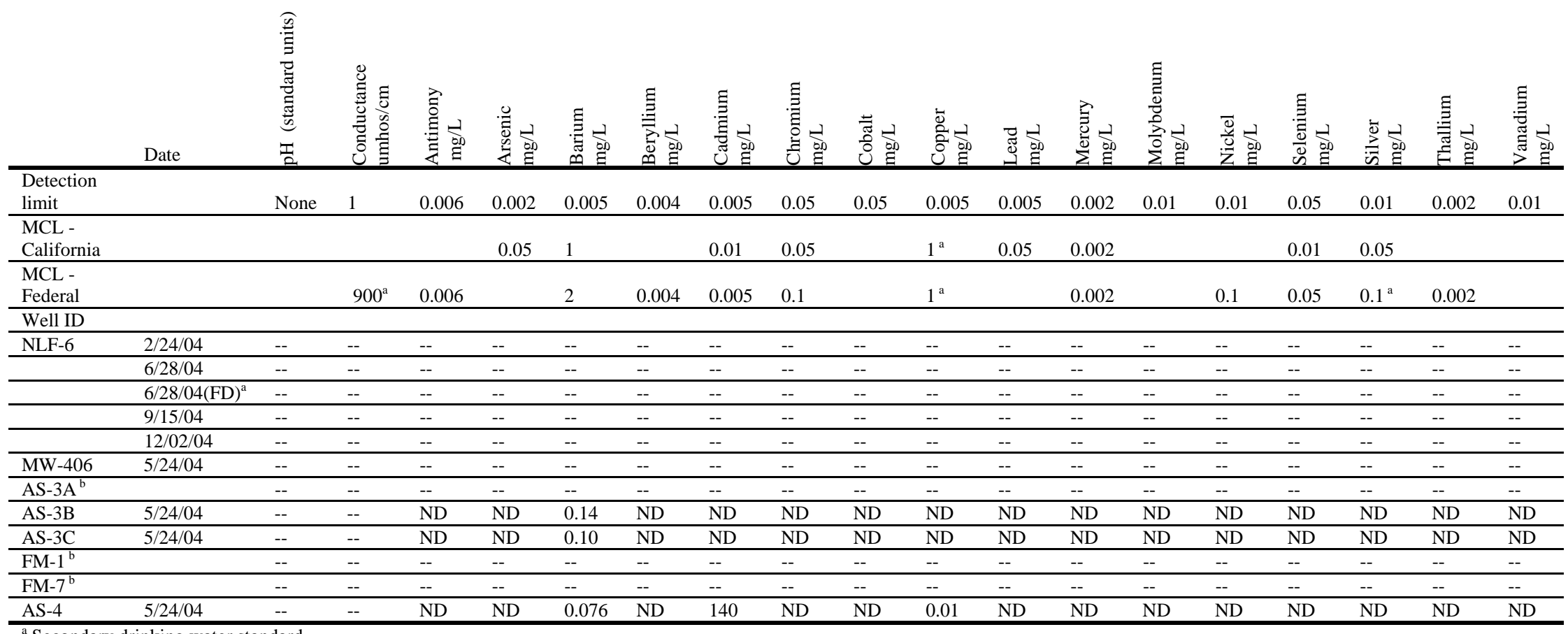

${ }^{\mathrm{a}}$ Secondary drinking water standard.

MCL - Maximum contaminant level.

ND - Non-detectable.

-- Not required to analyze or sample not collected.

${ }^{\text {a }}$ Field duplicate sample.

${ }^{\text {b }}$ Well was dry during 2004.

$9-4$ 
Table 9-1 Results of Groundwater Analyses at SNL/CA, 2004 (continued)

\begin{tabular}{|c|c|c|c|c|c|c|c|c|c|c|c|c|c|c|c|c|c|c|c|c|}
\hline & Date & 号茄 & 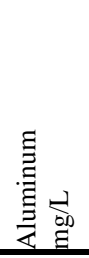 & 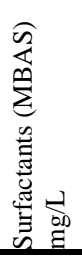 & 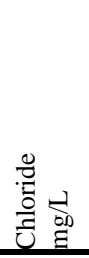 & 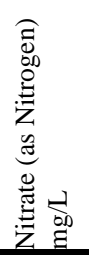 & 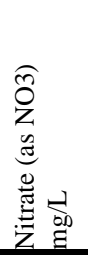 & 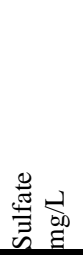 & 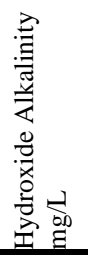 & 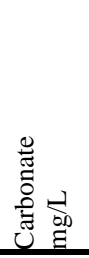 & 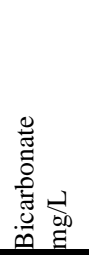 & 홀 & 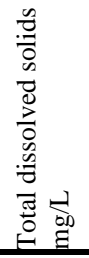 & 署 & 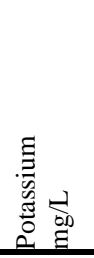 & 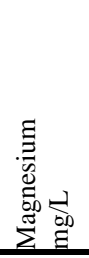 & 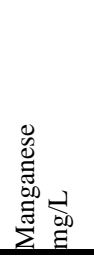 & 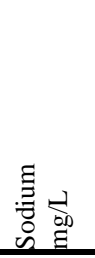 & 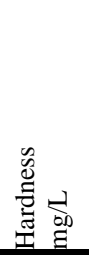 & 罡它 \\
\hline Detection limit & & 0.05 & 0.05 & 0.05 & 10 & 0.3 & 10 & 20 & 1 & 1 & 1 & 0.05 & 5 & 0.1 & 2 & 0.1 & 0.01 & 1.0 & 1 & 280 \\
\hline \multicolumn{21}{|l|}{ MCL - } \\
\hline MCL - Federal & & $5^{a}$ & $0.2^{\mathrm{a}}$ & $0.5^{\mathrm{a}}$ & $250^{\mathrm{a}}$ & 10 & & $250^{\mathrm{a}}$ & & & & $0.3^{\mathrm{a}}$ & $500^{\mathrm{a}}$ & & & $0.05^{\mathrm{a}}$ & $0.05^{\mathrm{a}}$ & & & \\
\hline \multicolumn{21}{|l|}{ Well ID } \\
\hline \multirow[t]{5}{*}{ NLF-6 } & $2 / 24 / 04$ & -- & -- & -- & -- & -- & -- & -- & -- & -- & -- & -- & -- & -- & -- & -- & -- & -- & -- & -- \\
\hline & $6 / 28 / 04$ & -- & -- & -- & -- & -- & -- & -- & -- & -- & -- & -- & -- & -- & -- & -- & -- & -- & -- & -- \\
\hline & $6 / 28 / 04(\mathrm{FD})^{\mathrm{a}}$ & -- & -- & -- & -- & -- & -- & -- & -- & -- & -- & -- & -- & -- & -- & -- & -- & -- & -- & -- \\
\hline & $9 / 15 / 04$ & -- & -- & -- & -- & -- & -- & -- & -- & -- & -- & -- & -- & -- & -- & -- & -- & -- & -- & -- \\
\hline & $12 / 02 / 04$ & -- & -- & -- & -- & -- & -- & -- & -- & -- & -- & -- & -- & -- & -- & -- & -- & -- & -- & -- \\
\hline MW-406 & $5 / 24 / 04$ & -- & -- & -- & -- & -- & -- & -- & -- & -- & -- & -- & -- & -- & -- & -- & -- & -- & -- & -- \\
\hline AS-3A ${ }^{b}$ & & -- & -- & -- & -- & -- & -- & -- & -- & -- & -- & -- & -- & -- & -- & -- & -- & -- & -- & -- \\
\hline AS-3B & $5 / 24 / 04$ & ND & ND & -- & -- & -- & -- & -- & -- & -- & -- & 0.07 & -- & 90 & 3.0 & -- & ND & 90 & -- & 420 \\
\hline AS-3C & $5 / 24 / 04$ & ND & ND & -- & -- & -- & -- & -- & -- & -- & -- & 0.07 & -- & 41 & 2.0 & -- & ND & 94 & -- & $80^{\mathrm{U}}$ \\
\hline $\mathrm{FM} 1^{\mathrm{b}}$ & & -- & -- & -- & -- & -- & -- & -- & -- & -- & -- & -- & -- & -- & -- & -- & -- & -- & -- & -- \\
\hline FM-7 $^{\mathrm{b}}$ & & -- & -- & -- & -- & -- & -- & -- & -- & -- & -- & -- & -- & -- & -- & -- & -- & -- & -- & -- \\
\hline AS-4 & $5 / 24 / 04$ & ND & 0.24 & -- & -- & -- & -- & -- & -- & -- & -- & 0.34 & -- & 140 & ND & -- & ND & 230 & -- & $150^{\mathrm{u}}$ \\
\hline
\end{tabular}

${ }^{\mathrm{a}}$ Secondary drinking water standard.

MCL - Maximum contaminant level.

ND - Non-detectable.

-- Not required to analyze or sample not collected.

${ }^{\text {a }}$ Field duplicate sample.

${ }^{\mathrm{b}}$ Well was dry during 2004.

"Result is less than the sample detection limit. 
Intentionally Left Blank 


\section{Distribution List}

\section{U.S. Department of Energy}

Karen Agogino (15)

U.S. Department of Energy

Sandia Site Office

P.O. Box 5400, MS 0184

Albuquerque, NM 87185-5400

Jeff Irwin (MS 9221)

DOE Facility Representative

Sandia National Laboratories, California

Connie Soden (2)

NNSA Service Center

U.S. Department of Energy

Pennsylvania \& H Street

Kirtland Air Force Base

Albuquerque, NM 87116

Alv Youngberg

NA-117/Germantown Bldg

U.S. Department of Energy

1000 Independence Ave, S.W.

Washington, D.C. 20585-1290

Dennis Miotla

NA-117/Germantown Bldg

U.S. Department of Energy

1000 Independence Ave, S.W.

Washington, D.C. 20585-1290

James Mangeno

NA-1

U.S. Department of Energy

1000 Independence Ave, S.W.

Washington, D.C. 20585

John Lehr

EM-34/Cloverleaf Bldg

U.S. Department of Energy

1000 Independence Ave, S.W.

Washington, D.C. 20585-2040
Ross Natoli (3)

EH-412/Forrestal Bldg

U.S. Department of Energy

1000 Independence Ave, S.W.

Washington, D.C. 20585

Ray Hardwick

EH-2/270 Corporate Square Building

U.S. Department of Energy

1000 Independence Ave, S.W.

Washington, D.C. 20585-0270

Glenn Podonsky

OA-1/Germantown Bldg

U.S. Department of Energy

1000 Independence Ave, S.W.

Washington, D.C. 20585-1290

Dave Stadler

EH-2

U.S. Department of Energy

1000 Independence Ave. S.W.

Washington, D.C. 20585

Norbert Golchert

Argonne National Laboratory

9700 S. Cass Avenue

Building 200, Room B-11

Argonne, IL 60439

Roger Dirkes

Battelle Pacific Northwest Laboratories

P.O. Box 999

Richland, WA 99352

Eva Hickey

Battelle Pacific Northwest Laboratories

P.O. Box 999, MS K-3-66

Richland, WA 99352 
Michael Ruggieri

Lawrence Berkeley National Laboratory

One Cyclotron Road

Berkeley, CA 94720

Lars Soholt

Los Alamos National Laboratory

Environmental Surveillance Group

P.O. Box 1663, MS-K490

Los Alamos, NM 87545

Tom Buhl

Los Alamos National Laboratory

Environmental Surveillance Group

P.O. Box 1663, MS-K490

Los Alamos, NM 87545

John Murphy

Oak Ridge National Laboratory

P.O. Box 2008

MS-6198

Oak Ridge, TN 37831-6198

Jim Heffner

Savannah River Plant

Environmental Monitoring

Health Protection Department

Building 735A

Aiken, SC 29809

Don Cassairt

Fermilab

P.O. Box 500

Batavia, IL 60510

Arthur Biermann (L-629)

Lawrence Livermore National Laboratory

7000 East Avenue

Livermore, CA 94550

Ellen Raber (L-626)

Lawrence Livermore National Laboratory

7000 East Avenue

Livermore, CA 94550

Robert Bainer (L-627)

Lawrence Livermore National Laboratory

7000 East Avenue

Livermore, CA 94550
William Hoppes (L-627)

Lawrence Livermore National Laboratory

7000 East Avenue

Livermore, CA 94550

LLNL Public Information Office (L-790)

Lawrence Livermore National Laboratory

7000 East Avenue

Livermore, CA 94550

\section{Other Federal Agencies}

M. Dermer

U.S. Environmental Protection Agency

Region IX

75 Hawthorne Street

San Francisco, CA 94105

D. McGovern

U.S. Environmental Protection Agency

Region IX

75 Hawthorne Street

San Francisco, CA 94105

Richard Lessler

U.S. Environmental Protection Agency

Region IX

75 Hawthorne Street

San Francisco, CA 94105

Joy Haftel

Congressional Information Services

4520 East-West Highway

Suite 800

Bethesda, MD 20814

Paul Weiss

Congressional Information Services

4520 East-West Highway

Suite 800

Bethesda, MD 20814

The Honorable Ellen Tauscher

U.S. House of Representatives

California $10^{\text {th }}$ District

1801 N. California, Suite 103

Walnut Creek, CA 94596 
The Honorable Ellen Tauscher

U.S. House of Representatives

California $10^{\text {th }}$ District

1239 Longworth House Building

Washington DC 20515

\section{State and Local Agencies}

E. Bailey

California Department of Health Services

Radiologic Health Branch

P.O. Box 942732

MS 178

Sacramento, CA 94234-7320

Stephen Woods

California Department of Health Services

Radiologic Health Branch

P.O. Box 942732

MS 178

Sacramento, CA 94234-7320

Stephen Hsu

California Department of Health Services

Radiologic Health Branch

P.O. Box 942732

MS 178

Sacramento, CA 94234-7320

J. Wong

California Department of Health Services

Environmental Management Branch

2151 Berkeley Way, Room 133

Berkeley, CA 94704

Laurent Meillier

California Regional Water Quality Control

Board

San Francisco Bay Region

1515 Clay Street

Oakland, CA 94612

S. Gittings

Livermore Water Reclamation Plant

101 West Jack London Boulevard

Livermore, CA 94550

D. Greenwood

Livermore Water Reclamation Plant

101 West Jack London Boulevard

Livermore, CA 94550
James Guthrie

Director of Enforcement Services

Bay Area Air Quality Management District

939 Ellis Street

San Francisco, CA 94109

Robert Weston

Alameda County

Health Care Services Agency

Department of Environmental Health Services 1131 Harbor Bay Parkway

Alameda, CA 94501

Daniel Murphy

California Environmental Protection Agency

Department of Toxic Substances Control

Region 2, Facility Permitting Branch

700 Heinz Avenue, Suite 200

Berkeley, CA 94710

Mike Miller

Public Services Director

City of Livermore

3500 Robertson Park Road

Livermore, CA 94550

Linda Barton

City Manager

City of Livermore

1052 S. Livermore Avenue

Livermore, CA 94550

The Honorable Guy Houston

California State Assembly

$15^{\text {th }}$ District

Capitol Building, Room 4208

Sacramento, CA 95814

The Honorable Guy Houston

California State Assembly

$15^{\text {th }}$ District

1365 Chestnut Street, Suite A

Livermore, CA 94550

Scott Haggerty

Supervisor District 1

Alameda County Board of Supervisors

1221 Oak Street, Suite 536

Oakland, CA 94612 
The Honorable Marshall Kamena

Mayor of Livermore

1052 South Livermore Avenue

Livermore, CA 94550

The Honorable Tom Torlakson

California State Senate

$7^{\text {th }}$ District

State Capitol Building, Suite 5061

Sacramento, CA 95814

The Honorable Tom Torlakson

California State Senate

$7^{\text {th }}$ District

2801 Concord Blvd.

Concord, CA 94519

Individuals and Organizations

Mike and Ann Mueller

2693 South Vasco Road

Livermore, CA 94550

Marylia Kelley

Tri-Valley CAREs

2528 Old First Street

Livermore, CA 94550

\section{Sandia National Laboratories}

MS 0101

MS 9001

MS 9405

MS 9007

MS 9054

MS 9002

MS 9403

MS 9003

MS 9221

MS 9221

MS 9221

MS 9221

MS 9221

MS 9221

MS 9221

MS 9221

MS 9221

MS 9221

MS 9221

MS 9221

MS 9131

MS 9111

MS 9031

MS 0342

MS 1139

MS 0141

MS 0141

MS 1042

MS 1042

MS 1042

MS 1151

MS 1089

MS 0939

MS 1087

MS 9018

MS 0899

MS 9021

MS 9021
T.O. Hunter, 1

M.E. John, 8000

R. Stulen, 8100

D. Henson, 8200

T. Michalske, 8300

P.N. Smith, 8500

J. Hruby, 8700

K. Washington, 8900

E. Cull, 8510

G. Shamber, 8516

B. Larsen, 8516 (30)

R. Holland, 8516

L. Gardizi, 8516

A. Leo, 8516

L. Farren, 8516

J. Harris, 8516

D.A. Wright, 8517

T.B. Garcia, 8517

M.E. Brynildson, 8517

J. Bartel, 8518

J. Manchester, 8528 (3)

M.E. Janes, 8528

K.C. Olsen, 11600

K. McCaughey, 6300

J. Moya, 6330

B. Krauss, 11000

A. Blumberg, 11100

C. Fink, 6331

S. Salinas, 6331

H.A. Hwang, 6331

J.J. Thompson, 6339

R.E. Fate, 6147

R.N. Coy, 6302

F.B. Nimick, 6140

Central Technical Files, 8945-1 (3)

Technical Library, 9615

Classification Office, 8511

Classification Office, 8511

for DOE/OSTI 
Sandia National Laboratories, California Site Environmental Report for 2004 